Review Article

\title{
Bioactive glasses incorporating less-common ions to improve biological and physical properties
}

\author{
Usanee Pantulap ${ }^{1} \cdot$ Marcela Arango-Ospina ${ }^{1}$ - Aldo R. Boccaccini ${ }^{1}{ }^{1}$
}

Received: 19 September 2021 / Accepted: 7 November 2021 / Published online: 23 December 2021

(c) The Author(s) 2021

\begin{abstract}
Bioactive glasses (BGs) have been a focus of research for over five decades for several biomedical applications. Although their use in bone substitution and bone tissue regeneration has gained important attention, recent developments have also seen the expansion of BG applications to the field of soft tissue engineering. Hard and soft tissue repair therapies can benefit from the biological activity of metallic ions released from BGs. These metallic ions are incorporated in the BG network not only for their biological therapeutic effects but also in many cases for influencing the structure and processability of the glass and to impart extra functional properties. The "classical" elements in silicate BG compositions are silicon ( $\mathrm{Si}$ ), phosphorous $(\mathrm{P})$, calcium $(\mathrm{Ca})$, sodium $(\mathrm{Na})$, and potassium $(\mathrm{K})$. In addition, other well-recognized biologically active ions have been incorporated in BGs to provide osteogenic, angiogenic, anti-inflammatory, and antibacterial effects such as zinc ( $\mathrm{Zn}$ ), magnesium $(\mathrm{Mg})$, silver $(\mathrm{Ag})$, strontium $(\mathrm{Sr})$, gallium $(\mathrm{Ga})$, fluorine $(\mathrm{F})$, iron $(\mathrm{Fe})$, cobalt $(\mathrm{Co})$, boron $(\mathrm{B})$, lithium $(\mathrm{Li})$, titanium (Ti), and copper $(\mathrm{Cu})$. More recently, rare earth and other elements considered less common or, some of them, even "exotic" for biomedical applications, have found room as doping elements in BGs to enhance their biological and physical properties. For example, barium (Ba), bismuth (Bi), chlorine $(\mathrm{Cl})$, chromium $(\mathrm{Cr})$, dysprosium (Dy), europium (Eu), gadolinium $(\mathrm{Gd})$, ytterbium $(\mathrm{Yb})$, thulium $(\mathrm{Tm})$, germanium $(\mathrm{Ge})$, gold $(\mathrm{Au})$, holmium (Ho), iodine (I), lanthanum (La), manganese $(\mathrm{Mn})$, molybdenum $(\mathrm{Mo})$, nickel $(\mathrm{Ni})$, niobium $(\mathrm{Nb})$, nitrogen $(\mathrm{N})$, palladium $(\mathrm{Pd})$, rubidium $(\mathrm{Rb})$, samarium $(\mathrm{Sm})$, selenium (Se), tantalum $(\mathrm{Ta})$, tellurium $(\mathrm{Te})$, terbium $(\mathrm{Tb})$, erbium (Er), tin $(\mathrm{Sn})$, tungsten $(\mathrm{W})$, vanadium $(\mathrm{V})$, yttrium $(\mathrm{Y})$ as well as zirconium $(\mathrm{Zr})$ have been included in BGs. These ions have been found to be particularly interesting for enhancing the biological performance of doped BGs in novel compositions for tissue repair (both hard and soft tissue) and for providing, in some cases, extra functionalities to the BG, for example fluorescence, luminescence, radiation shielding, anti-inflammatory, and antibacterial properties. This review summarizes the influence of incorporating such less-common elements in BGs with focus on tissue engineering applications, usually exploiting the bioactivity of the BG in combination with other functional properties imparted by the presence of the added elements.
\end{abstract}

These authors contributed equally: Usanee Pantulap, Marcela ArangoOspina

Aldo R. Boccaccini

aldo.boccaccini@ww.uni-erlangen.de
1 Department of Materials Science and Engineering, Institute of Biomaterials, University of Erlangen-Nuremberg, 91058 Erlangen, Germany 


\section{Graphical Abstract}

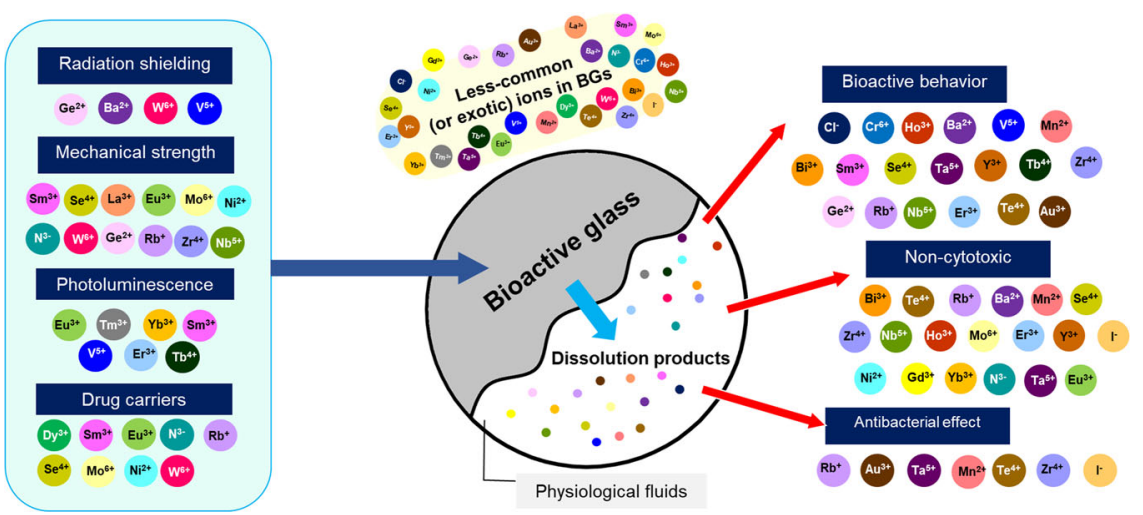

\section{Introduction}

Bioactive glasses (BGs) are being increasingly investigated for both bone and soft tissue engineering applications [1,2]. BGs exhibit a unique bone-bonding ability by forming a hydroxyapatite surface layer after incubation in physiological fluids and simultaneously support biological regenerative processes such as angiogenesis and osteogenesis during their dissolution $[3,4]$. Furthermore, specific compositions of BGs can provide antibacterial activity [5-8] and/or induce an anti-inflammatory response [9, 10]. BGs have thus great potential in bone regeneration, drug delivery systems, as well as in soft tissue repair and wound healing $[11,12]$. In 1969, Hench et al. used the $\mathrm{Na}_{2} \mathrm{O}-\mathrm{CaO}-\mathrm{SiO}_{2}$ phase diagram to develop the first $\mathrm{BG}$, named "45S5 BG," with composition: $45 \mathrm{SiO}_{2}-24.5 \mathrm{CaO}-6 \mathrm{P}_{2} \mathrm{O}_{5}-24.5 \mathrm{Na}_{2} \mathrm{O}$ (in wt.\%). 45S5 BG has been considered in medical applications since 1985. The first 45S5 BG surgical implants were solid parts used to replace the small bones in the middle ear to treat conductive hearing loss [13]. Over the last 50 years, numerous BG compositions in the silicate, borosilicate, borate, and phosphate systems have been developed and characterized [14-16]. In general, the addition of glass modifiers has significant effects on glass properties, including bioactivity. BG compositions similar to 45S5 BG have been investigated. For example, ICIE16$\mathrm{BG}$ [17], with a higher amount of $\mathrm{CaO}$ and lower amount of $\mathrm{Na}_{2} \mathrm{O}$ compared to $45 \mathrm{~S} 5 \mathrm{BG}$, along with $\mathrm{K}_{2} \mathrm{O}$, has been shown to exhibit a larger sintering window that allows the shaping of 3D structures without crystallization [18, 19]. Another silicate BG that has received much attention is the 13-93 composition, which has shown less tendency to crystallize when sintered and is known to generate 3D scaffolds with superior mechanical properties [20, 21]. Moreover, boron-containing BGs have demonstrated that boron addition into silicate BGs enhances the degradation rate [16], the process of apatite formation [22, 23], antibacterial properties [23], osteogenesis [24-26], angiogenesis [26-28], and has also an effect on the BG mechanical strength $[22,29]$. Boron-doped BGs have been shown to be attractive materials for applications in soft and hard tissue engineering [15, 30]. The chemical composition of phosphate-based BGs has also been studied to tailor the glass structure and to improve dissolution behavior and bioactive characteristics for biomedical applications $[31,32]$. The modification of chemical compositions of BGs has been investigated as an approach to improve mechanical properties and glass durability. For example, aluminum ions have been incorporated in $\mathrm{BGs}$ to reinforce mechanical performance. Various studies have investigated $\mathrm{Al}_{2} \mathrm{O}_{3^{-}}$ doped 45S5 BGs (sol-gel and melt-derived) in terms of bioactivity and physical properties, demonstrating improved mechanical properties but reduced bioactivity for compositions with more than $1 \mathrm{~mol} \% \mathrm{Al}_{2} \mathrm{O}_{3}$ compared to bare 45S5 BGs. Moreover, sol-gel glasses with low amounts of $\mathrm{Al}_{2} \mathrm{O}_{3}(0.5-1 \mathrm{~mol} \%)$ showed enhanced mechanical properties without significant reduction of bioactivity [33-36].

Biologically active ions have become widely used for enhancing the biological and physical effectiveness of BGs, aiming at developing multifunctional biomaterials for a wide range of biomedical applications. Metallic ions are not only essential for the human health but also could be an alternative to highly-priced pharmaceuticals [37, 38]. Significant research has been published on incorporating metallic ions (or bioinorganics) in BGs [39-43] as well as in the field of calcium phosphates [44-46]. The use of several biologically active ions has been prevalent in recent years, namely, $\mathrm{Ag}^{+}, \mathrm{Li}^{+}, \mathrm{Co}^{2+}, \mathrm{Ca}^{2+}, \mathrm{Cu}^{2+}, \mathrm{Zn}^{2+}, \mathrm{Sr}^{2+}, \mathrm{Fe}^{2+}$, $\mathrm{Mg}^{2+}, \mathrm{Ga}^{3+}$, and $\mathrm{B}^{3+}$ have been added to silicate, phosphate, and borate BG systems to promote functional properties such as osteogenesis, angiogenesis, bioactivity, antibacterial effects, and immunomodulation for tissue regeneration, as well as for infection and cancer treatment [40, 47, 48]. Several comprehensive reviews on such BGs 
Fig. 1 Periodic table of the elements highlighting the classical ions used to produce BGs, ions highly investigated to provide biological and therapeutic properties to BGs, and less-common ions in BGs, which are the ones covered in this review

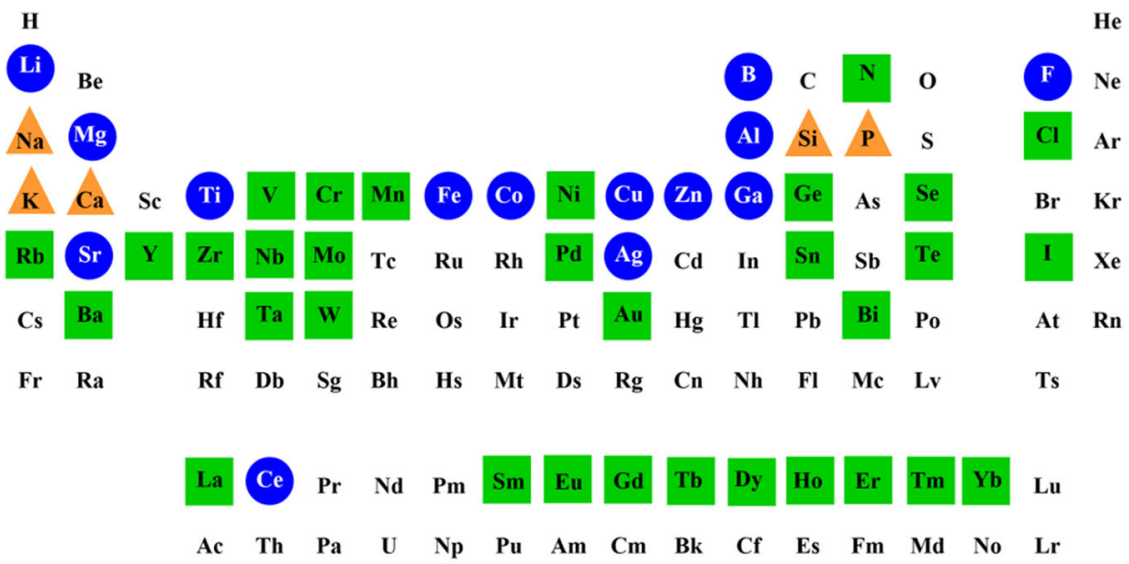

Classical ions in basic BG compositions

Common biologically active ions used in BGs

Less-common ions used in BGs (covered in this review) incorporating "common" biologically active ions are available [8, 15, 31, 39-42, 49-54].

Recently, a significant number of BGs doped with what can be called less-common (or even exotic) ions, including rare earth elements, have started to be reported. Such BGs are attractive for tissue regeneration applications because of the functional properties, biological activity, and therapeutic effects provided by such ions. There has been no previous review article focusing on the development and applications of such BGs containing less-common ions. Therefore, this review article covers comprehensively literature reports on less-common ion-doped BGs, which include rare earth, metal, and non-metal elements: $\mathrm{Ba}^{2+}, \mathrm{Bi}^{3+}, \mathrm{Cl}^{-}, \mathrm{Cr}^{6+}$, $\mathrm{Dy}^{3+}, \mathrm{Eu}^{3+}, \mathrm{Gd}^{3+}, \mathrm{Yb}^{3+}, \mathrm{Th}^{3+}, \mathrm{Ge}^{2+}, \mathrm{Au}^{3+}, \mathrm{Ho}^{3+}, \mathrm{I}^{-}, \mathrm{La}^{3+}$, $\mathrm{Mn}^{2+}, \mathrm{Mo}^{6+}, \mathrm{Ni}^{2+}, \mathrm{Nb}^{5+}, \mathrm{N}^{3-}, \mathrm{Pd}^{2+}, \mathrm{Rb}^{+}, \mathrm{Sm}^{3+}, \mathrm{Se}^{4+}$, $\mathrm{Ta}^{5+}, \mathrm{Te}^{4+}, \mathrm{Tb}^{3+}, \mathrm{Er}^{3+}, \mathrm{Sn}^{2+}, \mathrm{W}^{6+}, \mathrm{V}^{5+}, \mathrm{Y}^{3+}$, and $\mathrm{Zr}^{4+}$. Figure 1 shows the periodic table of the elements highlighting the different ions that are considered basic constituents for the production of BGs or those mainly used to impart biological and therapeutic functionalities to BGs. An overview of BG formulations incorporating less-common ions, their applications and properties, including the synthesis method, is presented in Table 1 for rare earth elements and Table 2 for other less-common (biologically active) ions. Considering the increasing number of publications in the field of ion-doped BGs, the authors proposed a basic classification of the ions based on their primary function in the BG and, for the purpose of this review, the number of studies that have considered the respective ions for their biological effects. Based on the information shown in Fig. 2, the selection of ions for such classification, and thus the decision on which publications should be included in this review, was done considering the number of publications reporting the application of a given ion in BGs in the last 20 years. Ions used in less than 30 publications (up to August 31, 2021) were considered "less-common ions" and were thus included in this review (clearly this is an arbitrarily chosen number, but necessary to establish a criterion to identify such less-common ions).

\section{Rare earth elements-containing bioactive glasses}

The incorporation of biologically active ions, including less-common ions, provides BG matrices with additional biological functionalities, therapeutic effects, and physical properties, for example, induction of hydroxyapatite formation, enhanced differentiation and proliferation of boneforming cells, stimulating effects on angiogenic growth factors and improvement in mechanical properties [41]. Several studies have reported the use of rare earth elements in BGs to achieve different biological and functional properties. In this section, the effects of the incorporation of rare earth elements in different types of BGs are discussed.

\subsection{Europium (Eu)}

$\mathrm{Eu}$ is a rare earth element that is not naturally present in the human body; however, as other elements, it can be incorporated into the body via ingestion of food and inhalation of dust particles. Normally these elements are naturally eliminated, but small amounts may deposit in organs. Traces of Eu have been found in brain tissue and kidney stones [55]. Due to the luminescent properties of $\mathrm{Eu}^{3+}$ ions, silicate and phosphate bioactive glasses doped 


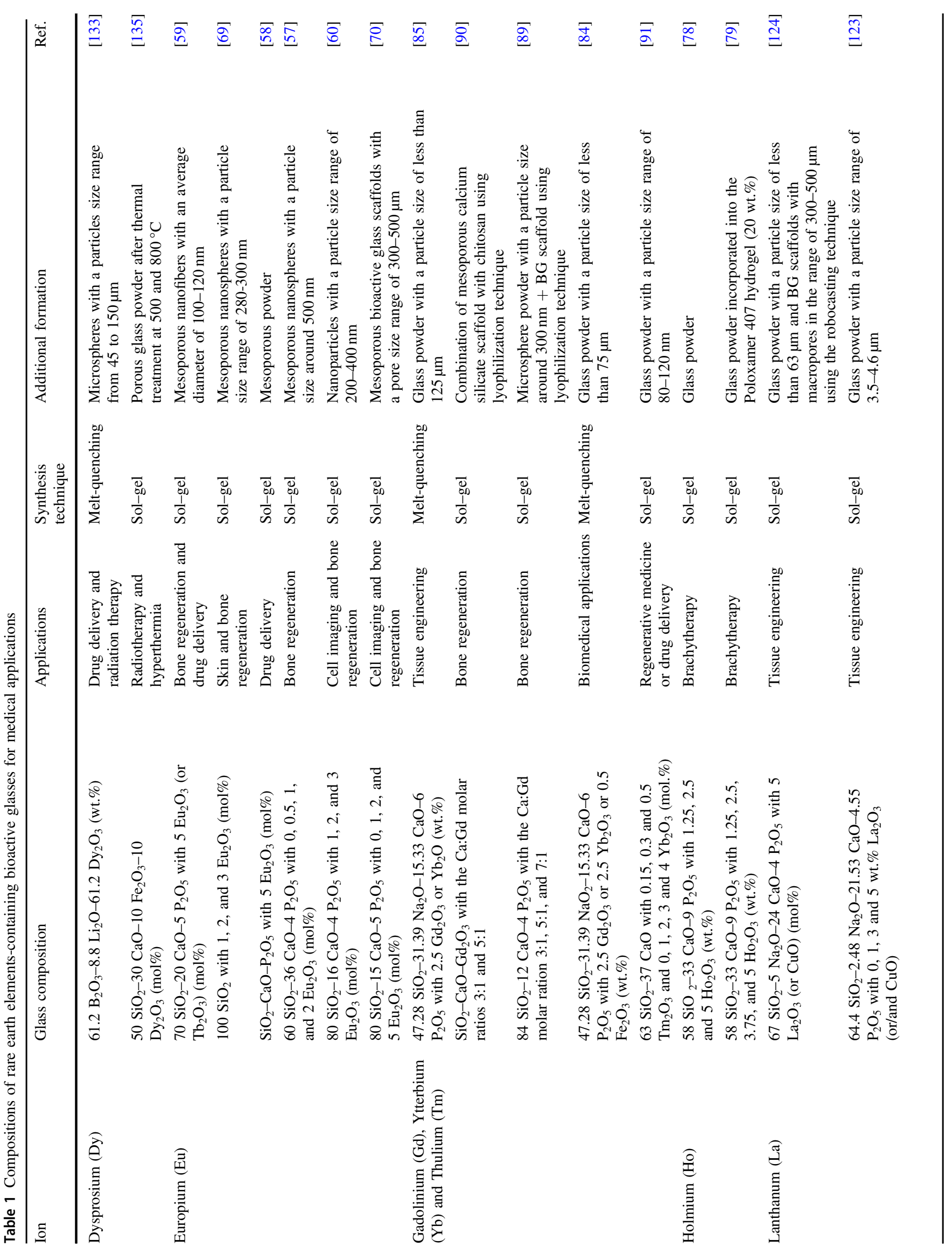




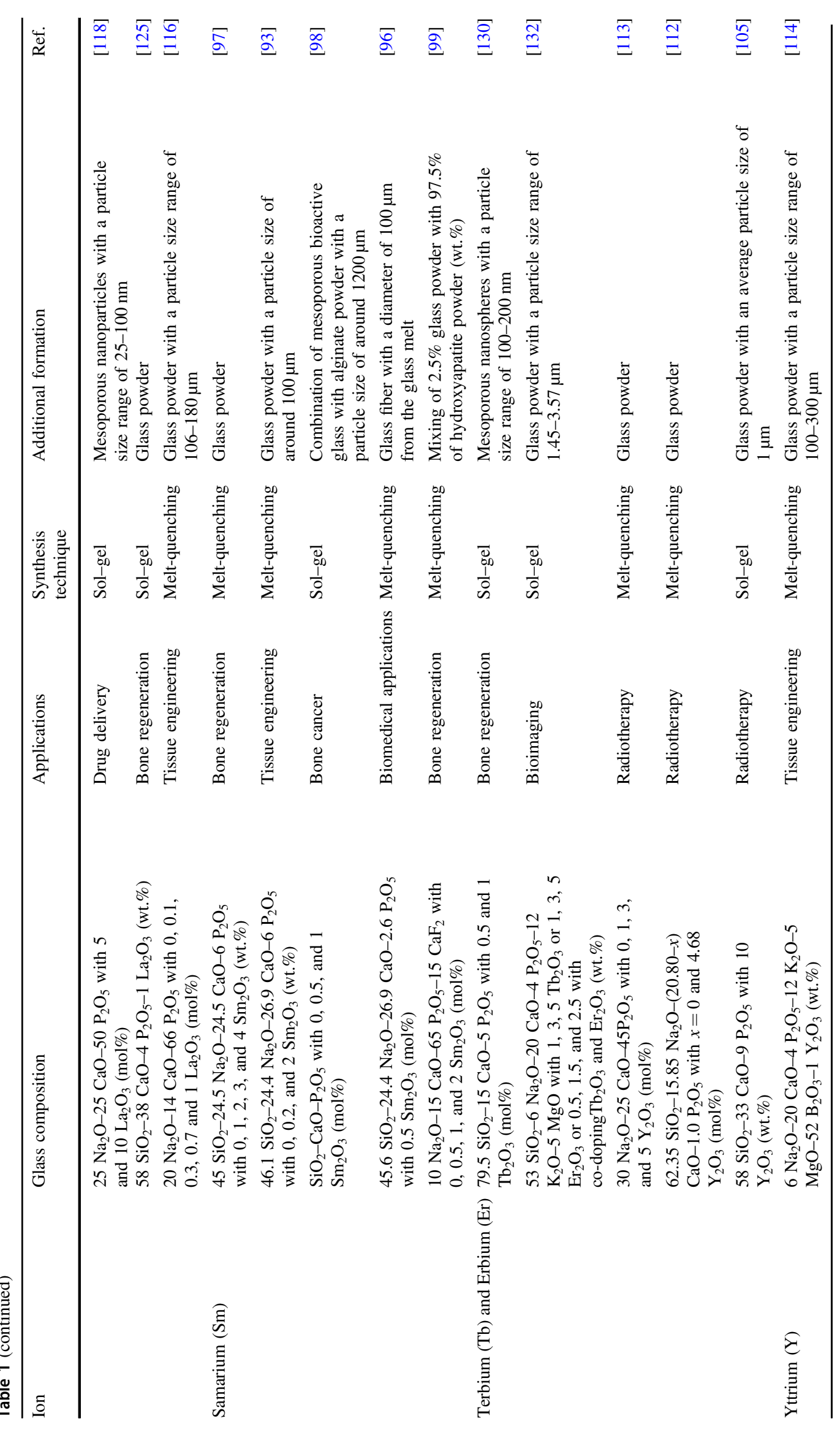




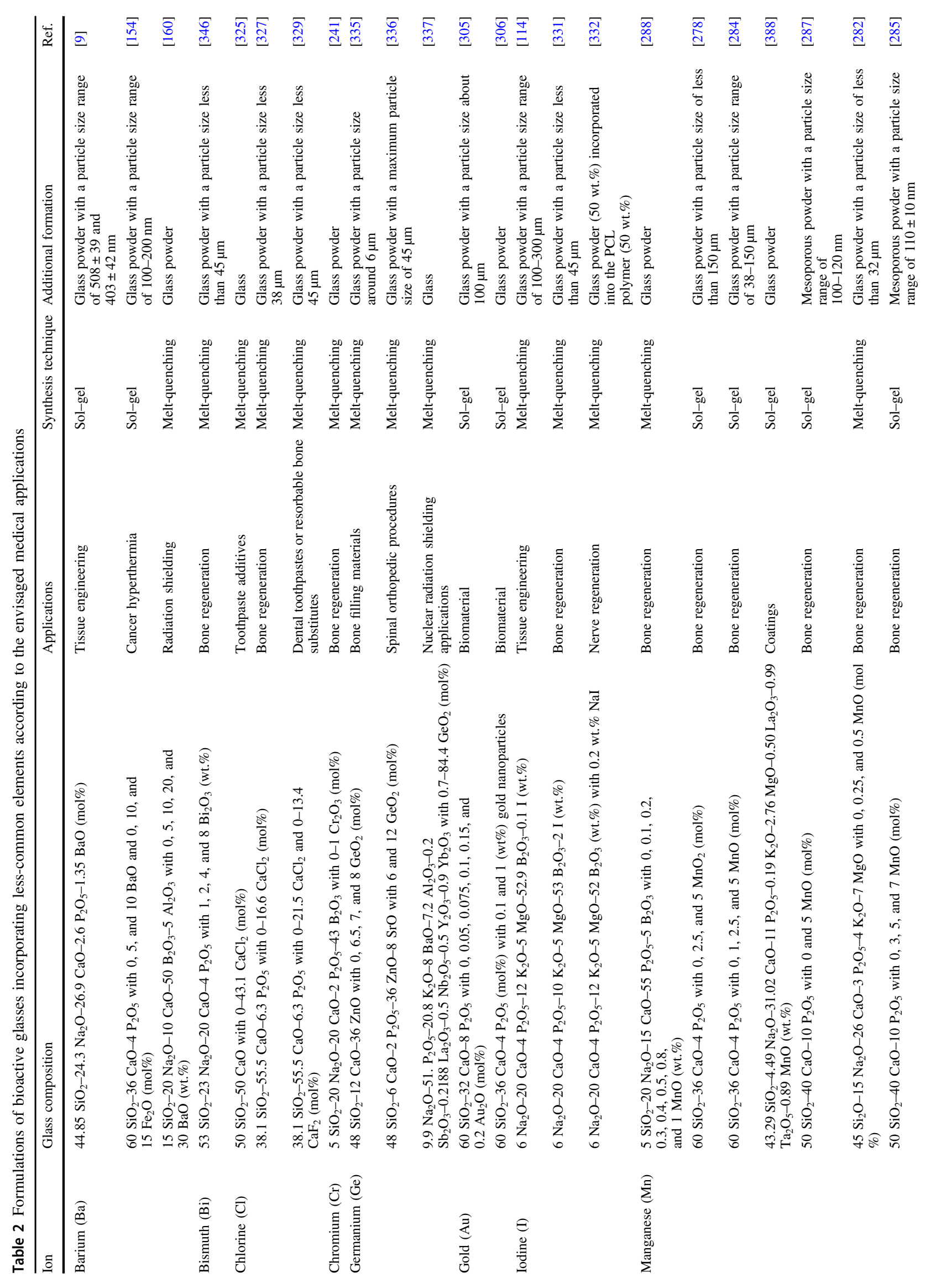




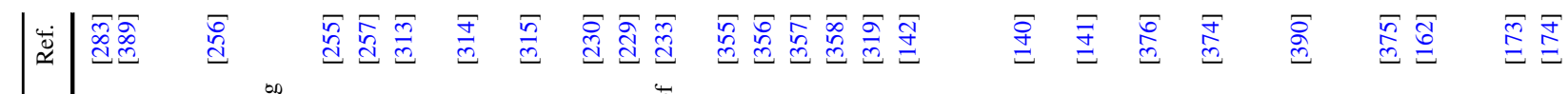

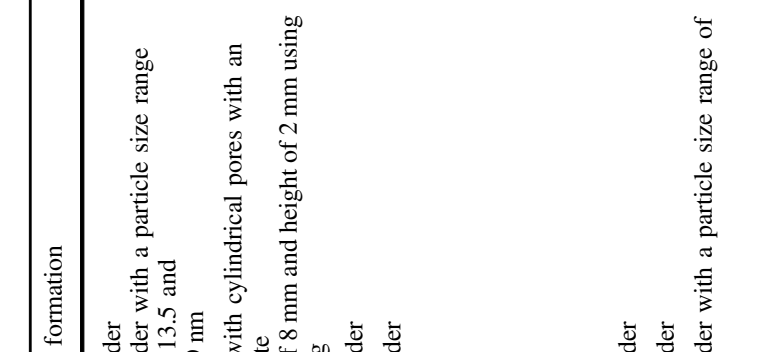

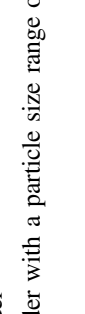

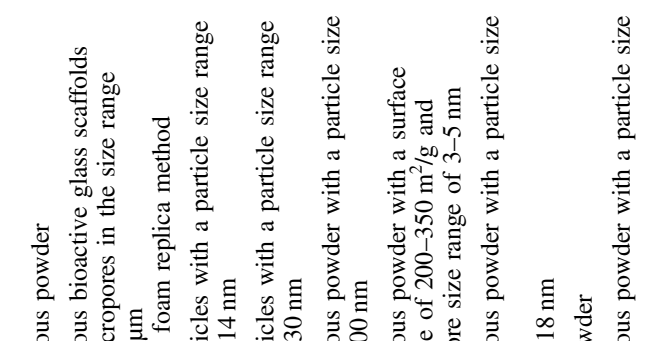

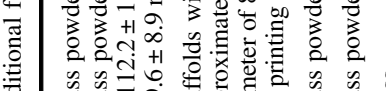

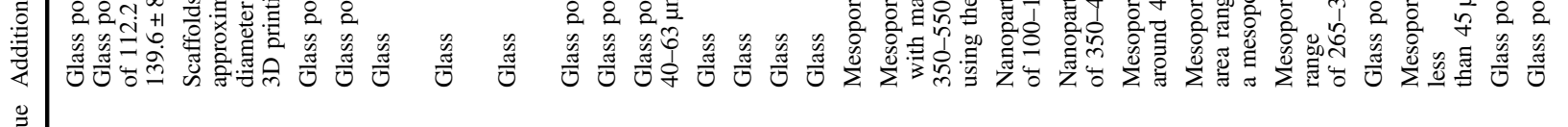

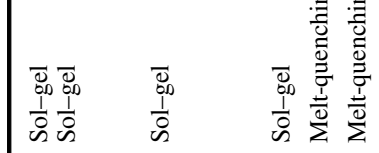
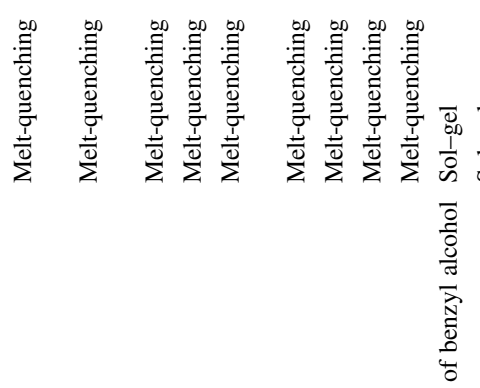

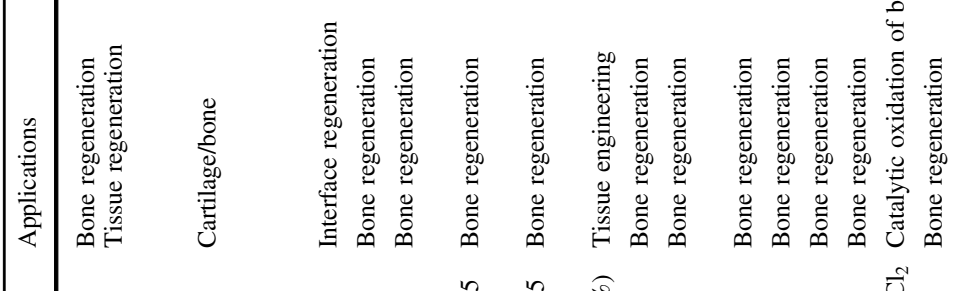

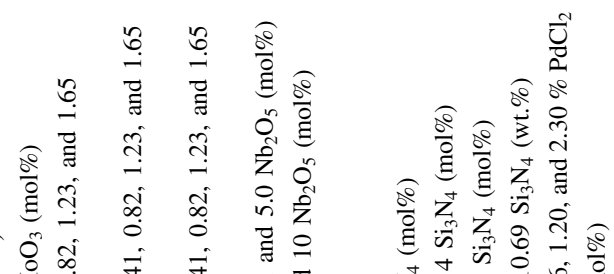

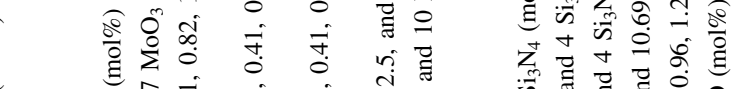

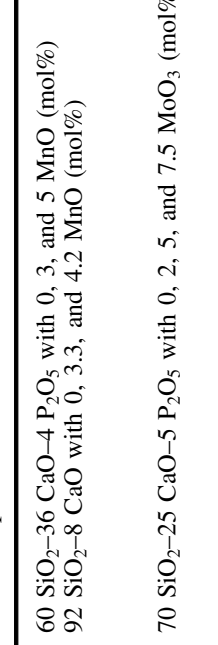

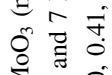

:

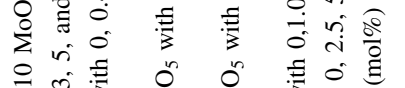

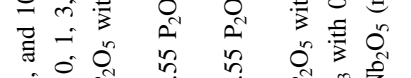

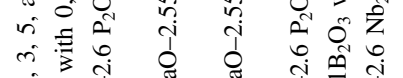

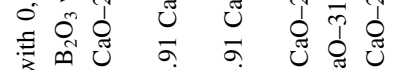

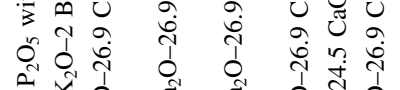

पो

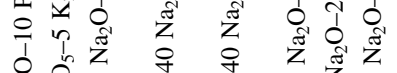

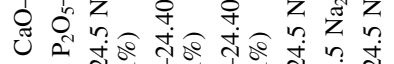

o o to

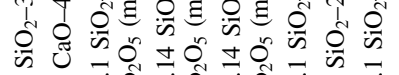

衰

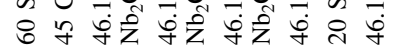

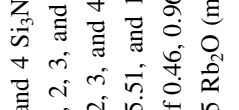

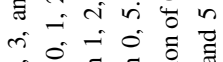

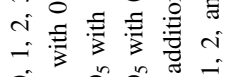

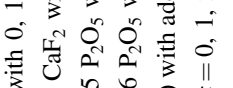

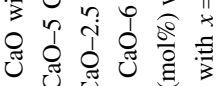

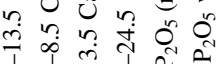

1 i 1202

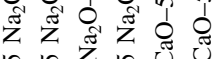

m n

0
0
0

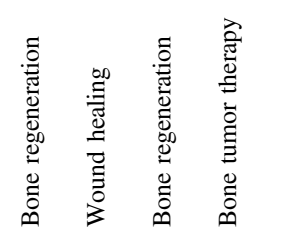

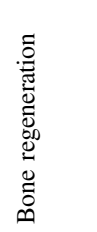

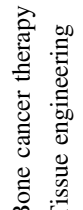

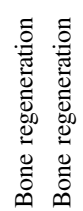

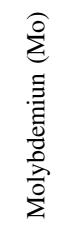

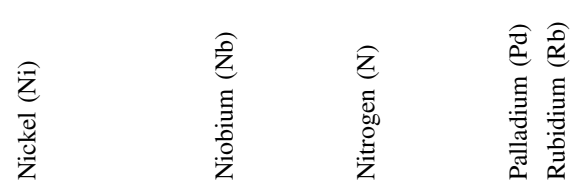

迎

焉

을

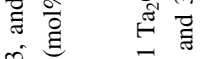

กิ

经

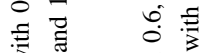

on का क्षे

ती: क्ष

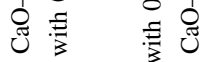

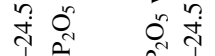

की के

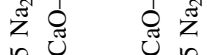

少 的

की

r $\infty$ in $\frac{1}{2}$

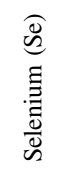

שֶ 


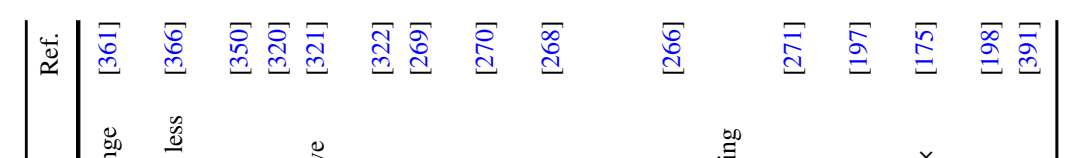

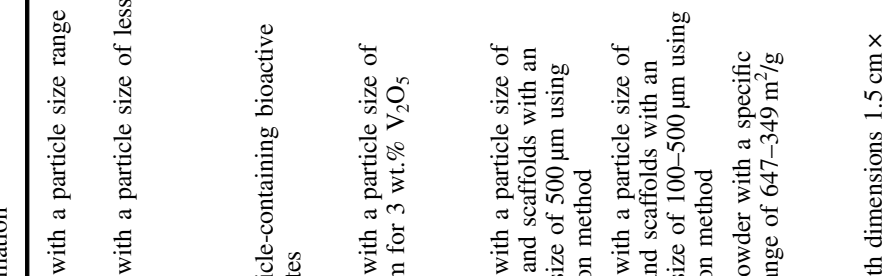

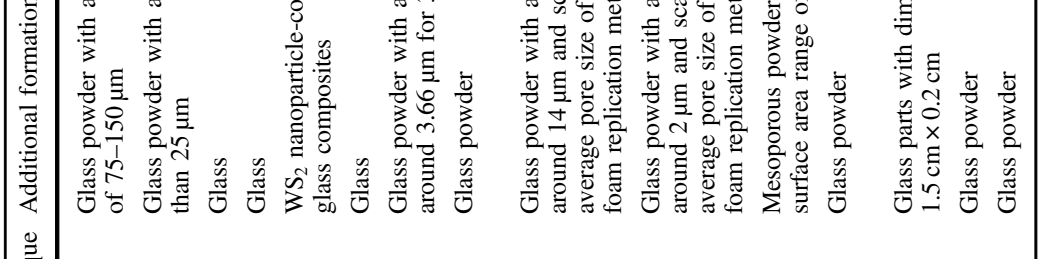

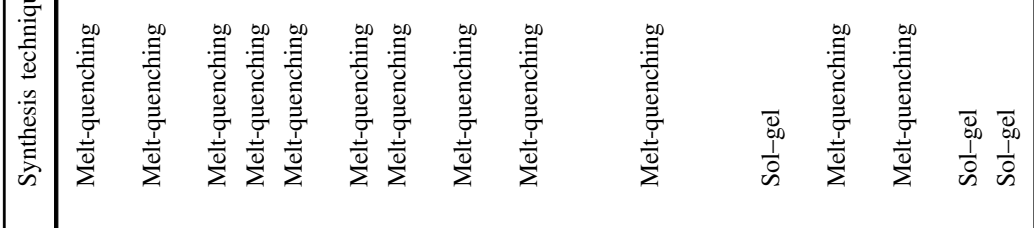

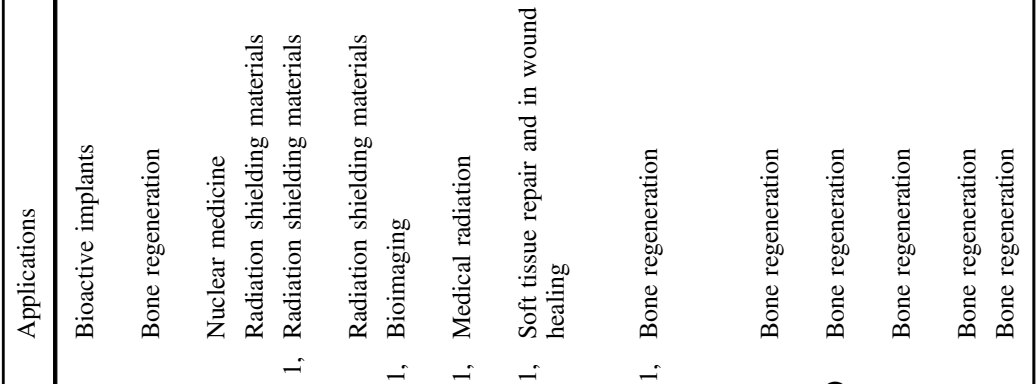

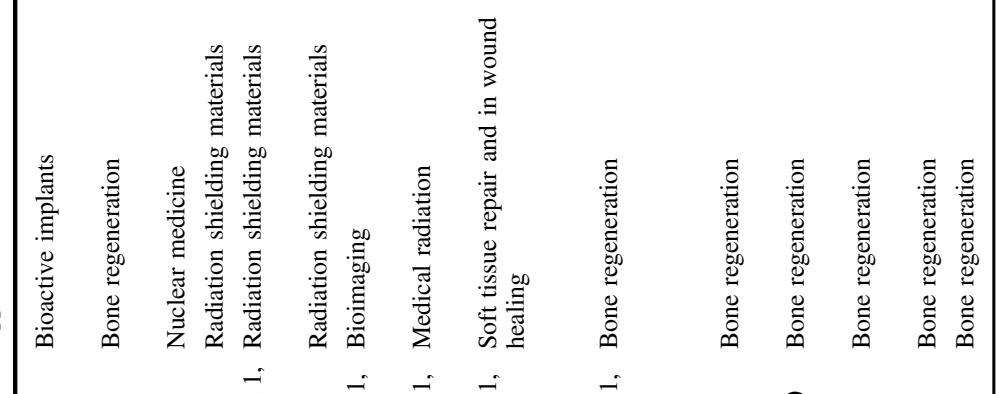

$$
\begin{aligned}
& \text { 兽 }
\end{aligned}
$$

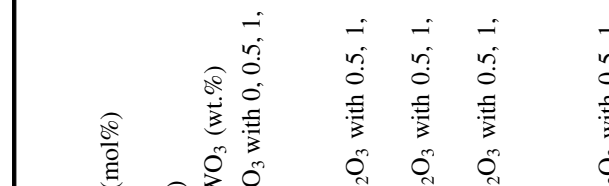

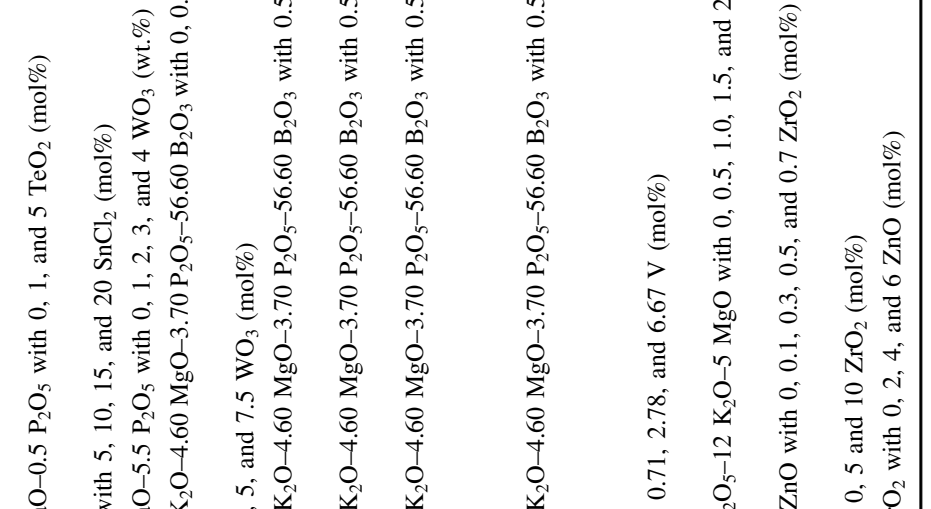

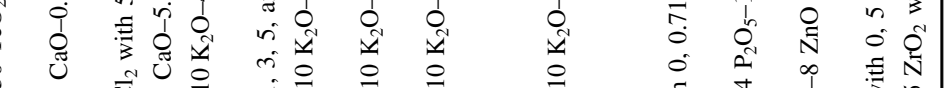

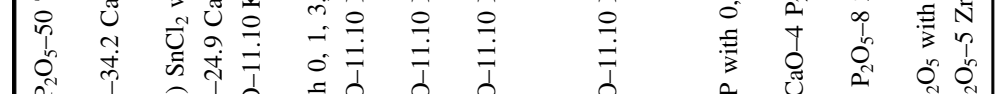

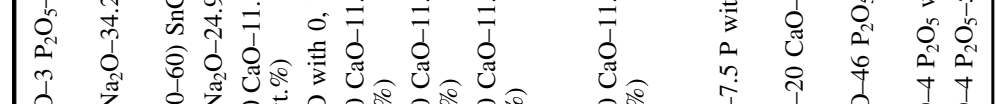

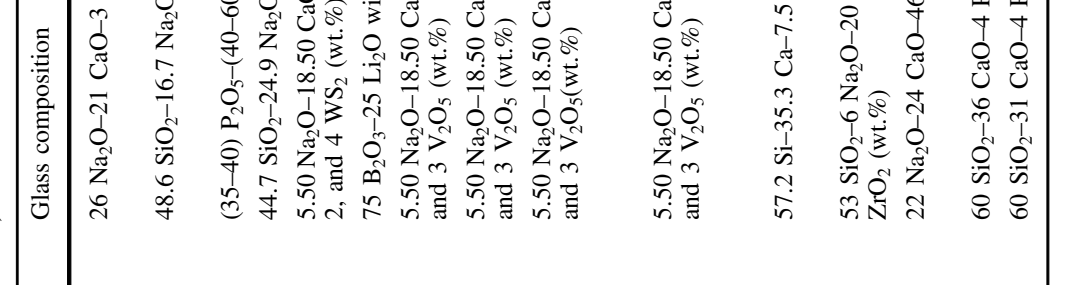

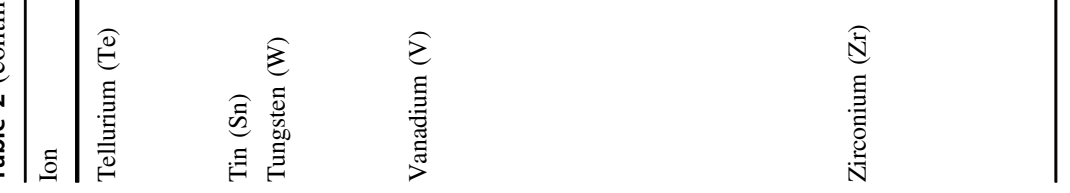




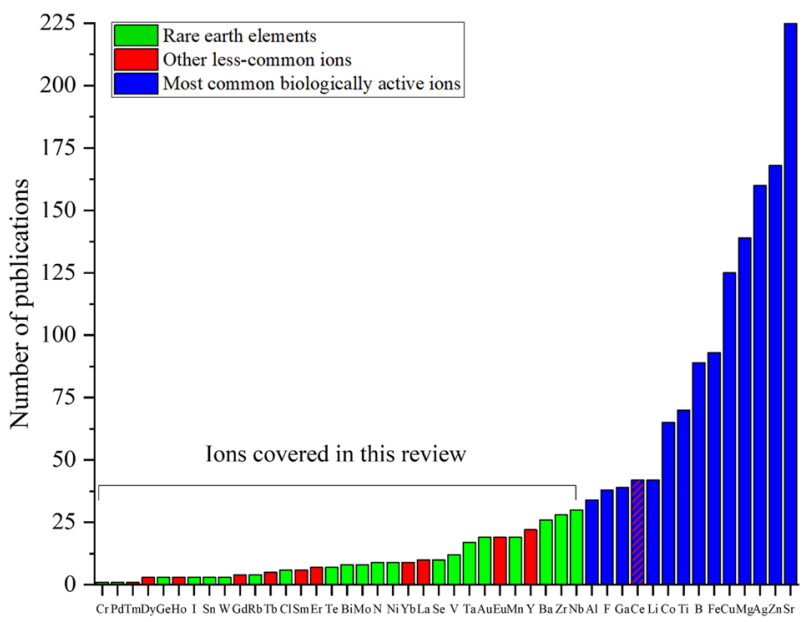

Fig. 2 Number of publications in the last 20 years containing the keywords "bioactive glasses" or "bioglass" and the corresponding ions. The criteria used for the search considered that the keywords should appear on the title of the publication and//or the abstract. Data obtained from the database Scopus (www.scopus.com) and Web of Science (www.webofscience.com)

with europium (Eu-BGs) have been designed for applications in drug delivery systems [56-59], cell imaging [60-67], optical devices [68], and bone and skin regeneration [69-74]. Eu-BGs were shown to emit strong red luminescence features at $590 \mathrm{~nm}$ and $612-616 \mathrm{~nm}$ when exposed to UV radiation $[56,69,70]$. In other studies, the intensity of emission was found to increase as the fraction of europium ions increased [69, 70]. The change in luminescence intensity of $\mathrm{Eu}^{3+}$ has been monitored to track the release of ibuprofen (IBU) [56, 58]. Fan et al. [58] observed the IBU release process using luminescence functionalized Eu-doped mesoporous bioactive glasses (Eu-MBGs) in the system $\mathrm{SiO}_{2}-\mathrm{CaO}-\mathrm{P}_{2} \mathrm{O}_{5}$. The release of IBU from Eu-MBG in SBF increased the photoluminescence intensity of $\mathrm{Eu}^{3+}$ at 590 and $621 \mathrm{~nm}$, reaching the highest value when IBU was completely removed. The quenching effect was weakened by the release of IBU, resulting in the increase of emission intensity [56, 58]. Moreover, Huang et al. [59] showed that the IBU release rate of Eu-doped mesoporous bioactive glass nanofibers (MBGNFs) with $5 \mathrm{~mol} \% \mathrm{Eu}^{3+}$ $\left(\right.$ or $\mathrm{Tb}^{3+}$ ) in the system $70 \mathrm{SiO}_{2}-25 \mathrm{CaO}-5 \mathrm{P}_{2} \mathrm{O}_{5}(\mathrm{~mol} \%)$ was more rapid than for IBU-loaded MBG due to the disordered nanoporous channels present in the nanofibers. Zhang et al. [57] observed that increasing concentration of Eu in MBG nanospheres with composition $60 \mathrm{SiO}_{2}-(36-$ x) $\mathrm{CaO}-x \mathrm{Eu}_{2} \mathrm{O}_{3}-4 \mathrm{P}_{2} \mathrm{O}_{5}, x=0.5,1$, and $2 \mathrm{~mol} \%$, changed the size, morphology, and pore structure of mesoporous silica supporting a controlled release of doxorubicin (DOX), a drug used for cancer treatment [57]. Xue et al. [60] demonstrated that fluorescent $\mathrm{Eu}$ ions in BG nanoparticles $\left(80 \mathrm{SiO}_{2}-16 \mathrm{CaO}-4 \mathrm{P}_{2} \mathrm{O}_{5} \mathrm{~mol} \%\right)$ were used to mark living murine calvaria-derived pre-osteoblastic (MC3T3-E1) cells for in vitro cytotoxicity studies with high red fluorescence and low background noise. Besides, $\mathrm{Wu}$ et al. [70] investigated the degradation of Eu-MBGs scaffolds $\left(80 \mathrm{SiO}_{2}-15 \mathrm{CaO}-5 \quad \mathrm{P}_{2} \mathrm{O}_{5}, \mathrm{~mol} \%\right)$ using a spectrofluorimeter to measure luminescence intensity at $615 \mathrm{~nm}$. Also, they detected in vivo new bone formation in a bone defect promoted by Eu ions release (wavelength of $610 \mathrm{~nm}$ ), indicating that Eu addition can have also a biological effect, as discussed next.

Eu-BGs have shown bioactive behavior in SBF $[57,60]$. Eu incorporation in BG nanoparticles had no significant effect on apatite mineralization [60], although the morphology of the formed apatite layer changed as the doping Eu content raised [57]. Moreover, Wu et al. observed that ionic dissolution products of $\mathrm{Eu}-$ containing MBGs $(5 \mathrm{~mol} \%)$ at varying concentrations (from 6.25 to $100 \mathrm{mg} / \mathrm{ml}$ ) facilitated proliferation and osteogenic differentiation of bone marrow stromal cells (BMSCs) by upregulating the expression of osteogenic genes (Runx2, COL1, OPN, OSX, and BSP) and by inducing ALP activity $(6.25$ and $25 \mathrm{mg} / \mathrm{ml})$. However, the ALP activity decreased when the glass concentration was increased to $100 \mathrm{mg} / \mathrm{ml}$. These results were compared to a control group that did not have conditioned medium. Similarly, europium-doped mesoporous silica nanospheres (Eu-MSNs) have been shown to substantially upregulate osteogenic markers (ALP, OPN, OCN, COL1, and Runx2) of BMSCs and to enhance the expression levels of CD31, PDGFR $\alpha / \beta$, VEGFR1/2, and MMP9 angiogenic makers of human umbilical vein endothelial cells (HUVECs) indicating the promotion of both osteogenic and angiogenic differentiation [69]. The addition of europium also had positive therapeutic effects on pro-inflammatory macrophage cells (RAW 264.7) treated with Eu-MSN $(0.2 \mathrm{mg} / \mathrm{ml})$, resulting in reduced pro-inflammatory genes IL-18, IL-6, IL-1 $\beta$, OSM MyD88, Ticam1, and Ticom2 [69]. In addition, 2 mol\% Eu-doped MSN and Eu-free MSN suspensions at a concentration of $0.2 \mathrm{mg} / \mathrm{ml}$ showed no cytotoxic effect on RAW 264.7 cells, while Eu-doped MSN induced macrophage proliferation. In contrast, non-doped MSN had no effect on macrophage proliferation [69]. Similarly, other studies have shown that Eu-BG had no cytotoxic effect on MC3T3-E1 cells at concentrations ranging from 40 to $250 \mu \mathrm{g} / \mathrm{ml}$ [60] and osteosarcoma MG 63 cells at different concentrations (between 50 and $200 \mu \mathrm{g} / \mathrm{ml}$ ) compared to undoped BG [57]. Other studies have reported the possible in vitro cytotoxicity of Eucontaining BGs [57, 60,69]. Moreover, in vivo studies of Eu-doped MSN have demonstrated that Eu accelerated the formation of new bone in a rat defect site after between 4 and 12 weeks of implantation $[69,70]$ and it 
promoted new blood vessels growth, collagen deposition, and re-epithelialization at the wound site [69].

\subsection{Holmium (Ho)}

It has been reported that holmium may have an influence on accelerating metabolism in humans [75]. In addition, Poniedzialek et al. [76] investigated the possible presence of Ho in human colostrum milk, developed at the first stage of breast milk. In the field of BGs, Ho has been used mainly in silicate-based systems [77-79]. For example, sol-gelderived holmium-doped $58 \mathrm{~S}$ bioactive glasses (Ho-BGs) with compositions $58 \mathrm{SiO}_{2}-33 \mathrm{CaO}-9 \mathrm{P}_{2} \mathrm{O}_{5}-x \mathrm{Ho}_{2} \mathrm{O}_{3}(x=$ $1.25,2.5$, and 5 wt. $\%$ ) have been shown to promote the proliferation of MC3T3-E1 cells in relation to the concentrations of $\mathrm{Ho}_{2} \mathrm{O}_{3}$ [78]. Moreover, the addition of $\mathrm{Ho}$ was shown to significantly affect the dissolution behavior due to the presence of Si-O-Ho covalent bonds in the glass network, which reduced the dissolution rate of the glass without slowing down the bioactive behavior. Ho-BG powders exhibited apatite-like structures on the surface for all $\mathrm{Ho}_{2} \mathrm{O}_{3}$ concentrations [78]. These results showed that Ho-containing BGs could be an interesting alternative for bone tissue regeneration. Zambanini et al. [79] investigated $58 \mathrm{~S}$ BGs $\left(58 \mathrm{SiO}_{2}-33 \mathrm{CaO}-9 \mathrm{P}_{2} \mathrm{O}_{5}\right)$ containing various amounts of $\mathrm{Ho}_{2} \mathrm{O}_{3}(1.25,2.5,3.75$, and 5 wt.\%) incorporated into a Poloxamer 407 hydrogel $(20 \mathrm{wt} . \%)$ for brachytherapy applications [80]. The hydrogel was integrated with $\mathrm{Ho}_{2} \mathrm{O}_{3}$ containing $\mathrm{BG}$, and it was found that the glass particles greatly influenced the hydrogel self-assembly potential. In contrast, the hydrogel viscosity was significantly reduced at $37^{\circ} \mathrm{C}$. Furthermore, the hydrogel containing $5 \mathrm{wt} \%$ Ho-BG particles enhanced the proliferation of MC3T3-E1 cells [79]. Clearly, given the scarcity of investigations, the potential of Ho-BGs in tissue engineering applications remains unexplored.

\subsection{Gadolinium (Gd), ytterbium (Yb), and thulium (Tm)}

Gd has been widely used in contrast agents for magnetic resonance imaging aimed to be eliminated naturally from the body; however, it has been shown that Gd could deposit in the brain and bones [55, 81, 82]. Similarly, Yb belongs to the lanthanide series of elements that are not naturally present in the human body. This element is highly used in optics and as a doping agent to increase the mechanical properties of stainless steel. Furthermore, $\mathrm{Yb}$ has been reported to accumulate in soils and water mainly due to petrol producing industries or discarded household equipment [83]. Silicate-based bioactive glasses doped with gadolinium (Gd-BG) and ytterbium (Yb-BG) have been investigated [84-88] due to the characteristic features that these elements offer for biomedical applications in the fields of brachytherapy, luminescence-based imaging, and magnetic resonance imaging [84]. In vitro bioactivity and biological studies have been performed on $\mathrm{Gd}$ and $\mathrm{Yb}$ containing $\mathrm{BGs}$ (of composition $47.28 \quad \mathrm{SiO}_{2}-31.39$ $\mathrm{Na}_{2} \mathrm{O}-15.33 \mathrm{CaO}-6 \mathrm{P}_{2} \mathrm{O}_{5}$ with $2.5 \mathrm{Gd}_{2} \mathrm{O}_{3}$ or $\mathrm{Yb}_{2} \mathrm{O}_{3}$ wt. \%), resulting in calcium phosphate deposition after 1 day of immersion in SBF and a lower dissolution behavior compared to the reference glass owing to the covalent character of the Si-O-Gd and Si-O-Yb bonds. In terms of cytocompatibility, the authors reported viability higher than $80 \%$ of mesenchymal stem cells derived from deciduous teeth (SHEDs) [85]. Moreover, gadolinium has been shown to have favorable therapeutic effect on osteoinductivity. For example, Zhu et al. [89] demonstrated that Gd-BG mesoporous microspheres in chitosan scaffolds facilitated the proliferation, differentiation, and expression of ALP activity, OCN, and BSP via Akt/GSK3 $\beta$ activation of human bone marrow-derived mesenchymal stem cells (hBMSCs). The AKT/GSK3 signaling pathway is crucial for the survival of human pluripotent stem cells (Fig. 3). Similarly, by triggering the Wnt/-catenin signaling pathway, Gd-doped mesoporous calcium silicate containing scaffolds facilitated the osteogenic potential of rBMSCs [90]. With Gd incorporation in $\mathrm{BG}$, the expression of osteogenic markers such as ALP activity, Runx2, and COL-1 increased [89, 90]. Furthermore, in vivo studies in a mouse model demonstrated that Gd-BG incorporation in chitosan scaffolds promoted rapid and significant newly formed bone and collagen deposition in a calvarial defect after 8-12 weeks implantation [89, 90].

Thulium has also been used with ytterbium to produce co-doped sol-gel-derived silica glass nanoparticles with different ratios of $\mathrm{Tm}_{2} \mathrm{O}_{3}$ and $\mathrm{Yb}_{2} \mathrm{O}_{3}$ for biological testing, bioimaging, and drug delivery systems [91]. Nanoparticles with basic $\mathrm{SiO}_{2}-\mathrm{CaO}$, containing $\mathrm{Tm}_{2} \mathrm{O}_{3}(0.15,0.3$, or 0.5 mol\%) and $\mathrm{Yb}_{2} \mathrm{O}_{3}(0,1,2,3$, or $4 \mathrm{~mol} \%)$, showed amorphous structure for lower dopant concentrations, while crystallization of calcium silicate was detected for the higher amounts of $\mathrm{Tm}_{2} \mathrm{O}_{3}$ and $\mathrm{Yb}_{2} \mathrm{O}_{3}$. The authors concluded that samples with $0.3 \% \mathrm{Tm}_{2} \mathrm{O}_{3}$ and $4 \% \mathrm{Yb}_{2} \mathrm{O}_{3}$ are promising due to their higher emission intensity and single exponential decay time compared to the other tested concentrations.

\subsection{Samarium (Sm)}

$\mathrm{Sm}$, an element that has in principle no natural biological role, has been widely used as a radiopharmaceutical to treat cancer in bones [92]. Sm-doped bioactive glasses (Sm-BG) have shown photoluminescence properties characteristic of $\mathrm{Sm}^{3+}$ ions and have been described as potential material for cancer treatment [93-95]. Baranowska et al. [96] used the luminescent 

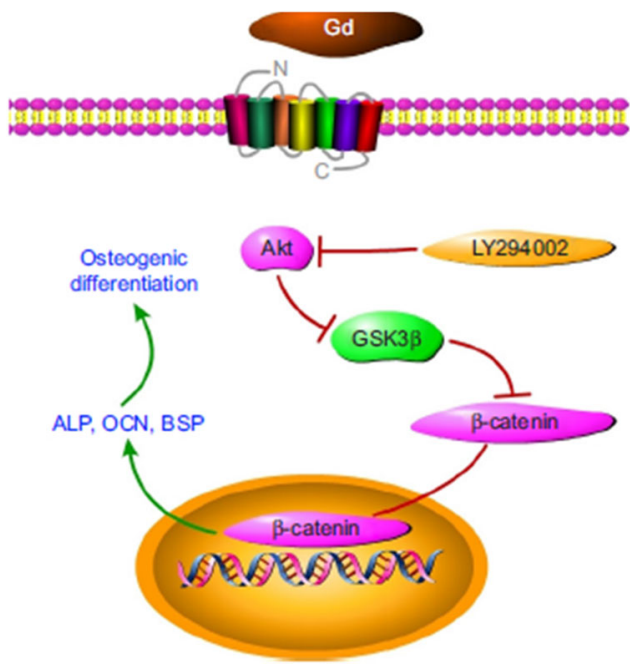

Fig. 3 Schematic diagram showing Gd dopant activation of the Akt/ GSK3 $\beta$ signaling pathway [89]. Reproduced according to Creative Commons license (CC BY-NC 3.0)

properties (at 601 and $648 \mathrm{~nm}$ ) of bioactive 45S5 BG fibers doped with $\mathrm{Sm}^{3+}$ to investigate the degradation behavior of the fibers. Furthermore, in vitro formation of apatite-like structures on Sm-BG substrates was observed after incubation in SBF by Ershad et al. [97]. The authors found that adding $\mathrm{Sm}_{2} \mathrm{O}_{3}$ to BGs up to a concentration of $3 \mathrm{wt} . \%$ increased the formation of hydroxycarbonate-apatite (HCA) layer on the surface after 21 days. Furthermore, Sm-BGs exhibited enhanced mechanical properties. Young's modulus $(76.36-78.89 \mathrm{GPa})$, shear modulus $(30.25-31.95 \mathrm{GPa})$, and bulk modulus of Smcontaining 45S5 BGs increased with increasing concentration of $\mathrm{Sm}_{2} \mathrm{O}_{3}$ [97]. Poisson's ratio, on the other hand, decreased as the concentration of $\mathrm{Sm}_{2} \mathrm{O}_{3}$ increased. [97]. In addition, Zhang et al. [98] investigated the potential use of samarium (0.5-1 mol\%) doped mesoporous BG and alginate-containing microspheres for drug delivery applications. The drug (DOX) was loaded in the microspheres with varying amounts of Sm. The release of DOX was proportional to the Sm doping concentration due to the higher dissolution rates proportional to the Sm concentration [98].

Morais et al. [99] investigated melt-derived samariumdoped phosphate glasses $\left(15 \mathrm{CaO}-10 \mathrm{Na}_{2} \mathrm{O}-15 \mathrm{CaF}_{2}-65\right.$ $\mathrm{P}_{2} \mathrm{O}_{5}$, with $\mathrm{Sm}_{2} \mathrm{O}_{3}$ ranging from 0.5 to $2 \mathrm{~mol} \%$ ) and hydroxyapatite to produce composites (BG-HA). A proportion of 2.5 wt. \% Sm-doped BG to 97.5 wt.\% hydroxyapatite was used to make the composites. XRD analysis showed crystalline phases characteristic of hydroxyapatite and samarium oxide. Moreover, the addition of $\mathrm{Sm}^{3+}$ ions in the composite increased surface hydrophilicity and flexural strength compared to Sm-free BG-HA. The highest concentration of $\mathrm{Sm}$ in the BG-HA composites affected in vitro the antibacterial activity and cytocompatibility behavior. Consequently, BG-HA doped with $2 \mathrm{~mol} \%$
$\mathrm{Sm}_{2} \mathrm{O}_{3}$ showed the best antibacterial performance against Staphylococcus aureus and S. epidermidis besides higher proliferation of MG 63 cells and upregulation of relevant osteogenic markers (Runx2, ALP, BMP-2, and OC) [99].

\subsection{Yttrium (Y)}

Yttrium has been used in the clinic in cancer treatment [92]. Various studies have investigated the incorporation of yttrium in BGs for applications in different fields including radiotherapy, dentistry, and bone tissue engineering [100109]. Yttrium-doped glasses (Y-BGs) have reported good chemical durability and stability in in vivo radiotherapy settings [110]. Erbe and Day [111] investigated the effect of the processability of $\mathrm{Y}$-containing glasses $\left(17 \mathrm{Y}_{2} \mathrm{O}_{3}-19\right.$ $\mathrm{Al}_{2} \mathrm{O}_{3}-64 \quad \mathrm{SiO}_{2} \quad \mathrm{~mol} \%$ ) on their chemical durability. Sol-gel-derived and melt-derived Y-doped glass microspheres have shown higher chemical durability than bulk particles due to their large surface area. $\mathrm{A} \mathrm{SiO}_{2}$-rich surface on the microspheres triggered surface corrosion after 4 weeks in DI water or $12 \mathrm{M} \mathrm{HCl}$. Moreover, the glass durability after the addition of $4.68 \mathrm{~mol} \%$ of $\mathrm{Y}_{2} \mathrm{O}_{3}$ in the BG composition $\left(62.35 \mathrm{SiO}_{2}-1.0 \mathrm{P}_{2} \mathrm{O}_{5}-15.85 \mathrm{Na}_{2} \mathrm{O}-20.8\right.$ $\mathrm{CaO} \mathrm{mol} \%$ ) was investigated by Christie et al. [112]. Molecular dynamics simulations revealed that the substitution of $4.68 \mathrm{~mol} \% \mathrm{Y}_{2} \mathrm{O}_{3}$ for $\mathrm{CaO}$ in the $\mathrm{BG}$ composition led to an increased dissolution rate compared to $\mathrm{Y}$-free $\mathrm{BG}$ due to the generation of a fragmented silicate network, causing a lower network connectivity and glass durability. The yttrium release rate was computed using site-selectivity and clustering of yttrium cations [112]. Arafat et al. [113] investigated the degradation rate after the incorporation of $\mathrm{Y}_{2} \mathrm{O}_{3}$ (3 and $5 \mathrm{~mol} \%$ ) in phosphate-based glasses (substitution for $\mathrm{Y}_{2} \mathrm{O}_{3} / \mathrm{Na}_{2} \mathrm{O}$ ) in phosphate buffer saline and ultra-pure water (Milli-Q water) at $37^{\circ} \mathrm{C}$ over 28 days. The results showed a reduced degradation rate with increasing $\mathrm{Y}_{2} \mathrm{O}_{3}$ content in the glass system $45 \mathrm{P}_{2} \mathrm{O}_{5}-25 \mathrm{CaO}-30$ $\mathrm{Na}_{2} \mathrm{O}$ (mol\%). In addition, Y-doped BGs have also exhibited bioactive behavior. Tesfay et al. [105], for example, observed that Y-containing 58S BG led to rapid apatite-like formation after $6 \mathrm{~h}$ in SBF. Recent work has also shown that replacing $\mathrm{B}_{2} \mathrm{O}_{3}$ with $1 \mathrm{wt} . \% \mathrm{Y}_{2} \mathrm{O}_{3}$ in the glass composition $53 \mathrm{~B}_{2} \mathrm{O}_{3}-20 \mathrm{CaO}-12 \mathrm{~K}_{2} \mathrm{O}-6 \mathrm{Na}_{2} \mathrm{O}-5 \mathrm{MgO}-4 \mathrm{P}_{2} \mathrm{O}_{5}$ (wt.\%) had a greater effect on the proliferation and migration of adipose stem cells (ASCs) in an $\alpha$-minimal essential medium in vitro [114].

\subsection{Lanthanum (La)}

$\mathrm{La}$ is a rare earth element that is present at low levels in drinking water and food. It has been reported to have chemical similarities to $\mathrm{Ba}, \mathrm{Sr}$, and $\mathrm{Ca}$ and has been recently investigated to replace calcium-based phosphate binders 
needed in patients with kidney failure to reduce cardiovascular calcification [115]. Therefore, tracing the accumulation of La in the body has become an important aspect for such applications, being bone the main accumulation site reported so far [81], next to breast milk [76] and brain tissue [55]. Lanthanum has been used to modify the properties of silicate and phosphate BGs [74, 116-122]. Lanthanum-doped bioactive glasses (La-BGs) containing chitosan composite scaffolds significantly improved osteoblast performance in terms of promoting the proliferation and osteogenic differentiation of BMSCs by upregulating expression levels of osteogenic markers (ALP, OCN, BMP-2, and Runx2) and raising the protein expression of RK in comparison to the scaffold without La doping [117]. In contact with HUVECs, La-BG-based scaffolds significantly induced the expression levels of b-FGF, vascular endothelial growth factor (VEGF), PDGF, and qRT-PCR compared to La-free BG scaffolds [117]. In vivo, the implantation of La-BG containing chitosan scaffolds in rat calvarial defects induced bone regeneration and new blood vessel formation after 8 weeks of implantation [117]. The addition of $\mathrm{La}_{2} \mathrm{O}_{3}$ (5 and $10 \mathrm{~mol} \%$ ) to phosphate glass nanoparticles provided a sustained delivery of the antibiotic ciprofloxacin for up to 28 days; on the other side, pure glass nanoparticles showed sustained drug release for 20 days [118]. The viability of fibroblast baby hamster kidney cells (BHK) after exposure to La containing nanoparticles exhibited a lanthanum oxide concentration dependency. The cell viability increased from 80 to $93 \%$ with increasing La concentration (from 0 to $10 \mathrm{~mol} \%$ ) [118]. Incorporation of lanthanum ions in combination with copper ions in BG facilitated the formation of a hydroxyapatite layer on the BG surface after soaking in SBF [123], suppressed C13895 lymphoblast cytotoxicity [123], and improved mechanical properties [124]. In addition, Jodati et al. [125] found multiple advantages of magnesium-lanthanum dual doped BGs (1 wt.\% La) in bone regeneration applications, with the glasses exhibiting increased bioactivity in terms of apatite formation ability and biocompatibility with SAOS-2 cells (human osteosarcoma).

\subsection{Terbium (Tb) and erbium (Er)}

$\mathrm{Tb}$ and Er have been used in medical imaging applications [75]. Bioactive glasses doped with terbium (Tb-BG) have been recently studied for biomedical applications because of their attractive properties, such as bioactivity, biocompatibility, biodegradation, and non-toxicity [126-129]. Wang et al. [130] investigated the influence of $\mathrm{Tb}$ on the apatite formation ability of mesoporous BG nanospheres (base composition: $79.5 \mathrm{SiO}_{2}-15 \mathrm{CaO}-5 \mathrm{P}_{2} \mathrm{O}_{5} \mathrm{~mol} \%$ ). It was reported that the incorporation of $\mathrm{Tb}_{2} \mathrm{O}_{3}(0.5$ and $1 \mathrm{~mol} \%)$ led to enhanced hydroxyapatite formation after immersion in SBF for 3 days. The hydroxyapatite nucleation on the surface of Tb-MBG nanospheres was seen to increase by the release of $\mathrm{Ca}^{2+}$ and $\mathrm{Tb}^{3+}$ ions. Furthermore, by varying $\mathrm{Tb}$ concentrations, it was possible to tailor DOX release [130]. Moreover, Tb-MBG nanospheres showed a nontoxic effect on MC3T3-E1 cells in indirect cell culture experiments at concentrations of 50 and $100 \mu \mathrm{g} / \mathrm{ml}$ [130]. Huang et al. [59] also evaluated the biocompatibility of $\mathrm{Tb}^{3+}$ (and $\mathrm{Eu}^{3+}$ ) containing MBGNFs using the MTT assay at different MBGNF concentrations $(3.125,6.25,12.5,25,50$, 100 , and $200 \mu \mathrm{m} / \mathrm{ml})$. In all conditions, the viability of L929 fibroblast cells was higher than $90 \%$, suggesting no cytotoxic effect of $\mathrm{Tb}^{3+}$ (or $\mathrm{Eu}^{3+}$ ) doped MBGNF. Under ultraviolet irradiation, Tb-MBGNF and Eu-MBGNF showed luminescence properties at 544 and $614 \mathrm{~nm}$, respectively [59].

Furthermore, Li et al. [128, 131] investigated co-doped BGs with $\mathrm{Er}$ and $\mathrm{Yb}$ to provide conventional BGs with luminescence properties for biological labeling and drug delivery applications. $\mathrm{Er}_{2} \mathrm{O}_{3}\left(0.79-3.52\right.$ wt.\%) and $\mathrm{Yb}_{2} \mathrm{O}_{3}$ (6.36-28.12 wt.\%) were incorporated in $\mathrm{Ca}-\mathrm{Mg}-\mathrm{Si} \mathrm{BGs}$ [131], as well as $\mathrm{Er}_{2} \mathrm{O}_{3}\left(1-2\right.$ wt.\%) and $\mathrm{Yb}_{2} \mathrm{O}_{3}(9-18$ wt.\%) in $\mathrm{CaSiO}_{3}$ [128]. In both investigations, bioactivity studies showed that co-doped BGs exhibited apatite precipitation in interaction with SBF after 14 days [128, 131]. Furthermore, these materials did not show cytotoxic behavior to MC3T3E1 cells, human dermal fibroblasts cells (HDFs), and HUVECs [128, 131]. In addition, culture of HDFs and HUVECs with the ionic extracts of the $\mathrm{Er}^{3+}$ and $\mathrm{Yb}^{3+}$ codoped $\mathrm{Ca}-\mathrm{Mg}$-Si BGs showed enhanced cell proliferation, expression of angiogenic genes and cell migration in comparison to non-doped glasses [131].

In a recent study, Deliormanli et al. [132] synthesized sol-gel-derived 13-93 BG doped with $\mathrm{Er}_{2} \mathrm{O}_{3}$ (1-5 wt.\%) and $\mathrm{Tb}_{2} \mathrm{O}_{3}\left(1-5\right.$ wt.\%) as well as co-doped BGs $\left(\mathrm{Er}_{2} \mathrm{O}_{3}\right.$ and $\mathrm{Tb}_{2} \mathrm{O}_{3}$ from 0.5 to $2.5 \mathrm{wt} . \%$ ). These BGs were successfully shaped into fibers via electrospinning. The addition of $\mathrm{Er}^{3+}$ and/or $\mathrm{Tb}^{3+}$ to the BG structure has been shown to affect the photoluminescence and decay times of the BG particles and nanofibers significantly. Consequently, the authors reported an effect of the BG morphology on the luminescence emission intensity and decay kinetics. The BG particles exhibited stronger emission intensity while the electrospun nanofibers longer decay times. Furthermore, the incorporation of $\mathrm{Er}^{3+}$ and/or $\mathrm{Tb}^{3+}$ into 13-93 BGs did not have an effect on hydroxyapatite formation after incubation in SBF for 30 days. The results were comparable to nondoped 13-93 BG particles and nanofibers, even at the highest doping concentration.

\subsection{Dysprosium (Dy)}

Dysprosium-containing glasses have been investigated as biodegradable radiation delivery vehicles for the treatment 
of rheumatoid arthritis [133]. Microspheres made of lithium borate glasses-containing dysprosium oxide have been reported in studies of Day et al. [133, 134]. Melt-derived microspheres of composition $30 \mathrm{Dy}_{2} \mathrm{O}_{3}, 8.8 \mathrm{Li}_{2} \mathrm{O}$, and 61.2 $\mathrm{B}_{2} \mathrm{O}_{3}$ (in wt.\%) have been further processed by a nonuniform reaction process with phosphate solutions to obtain highly porous dysprosium phosphate microspheres suitable for controlled delivery of drugs and radiation therapy. Moreover, Pătcaş et al. [135] investigated the structural changes of sol-gel silicate glasses containing dysprosium and iron after different thermal treatments (composition: 50 $\mathrm{SiO}_{2}, 30 \mathrm{CaO}, 10 \mathrm{Fe}_{2} \mathrm{O}_{3}, 10 \mathrm{Dy}_{2} \mathrm{O}_{3}$ in mol\%). Glasses treated at 500,800 , and $1200{ }^{\circ} \mathrm{C}$ exhibited decreasing surface area values at increasing temperature. Furthermore, nanocrystalline magnetite, hematite, and wollastonite phases were detected in the samples treated at 800 and $1200{ }^{\circ} \mathrm{C}$, which could lead to bioactive materials for applications on radiotherapy and hyperthermia.

\section{Bioactive glasses doped with other elements}

Elements belonging to different classifications in the periodic table such as alkali metals, transition metals and nonmetals have also been incorporated in BGs. Table 2 summarizes the glass compositions and applications of the described systems and specific examples are described in the following sections.

\subsection{Alkali and alkaline-earth metals}

\subsubsection{Rubidium $(\mathrm{Rb})$}

Rubidium $(\mathrm{Rb})$ is an important element present in human and animal tissues [136]. It is found in human organs such as the liver, kidneys, cerebrum, cerebellum, heart, pancreas, and spleen [137, 138]. The application of Rb-containing BGs has been focused on bone regeneration and wound healing [139-141]. For example, incorporation of 0.5, 1.5, and $2.5 \mathrm{~mol} \% \mathrm{Rb}_{2} \mathrm{O}$ in bioactive glass nanoparticles $(\mathrm{Rb}$ BGNs) of composition $90 \quad \mathrm{SiO}_{2}-10 \mathrm{CaO}$ (mol\%) with varying $\mathrm{CaO}: \mathrm{Rb}_{2} \mathrm{O}$ ratio was shown to increase the apatiteforming ability in SBF compared to Rb-free BGNs [140]. The greater ionic radius of $\mathrm{Rb}(1.48)$ relative to $\mathrm{Ca}(0.99)$ and $\mathrm{Si}(0.42)$ contributed to an open silica network structure and accelerated the release of $\mathrm{Rb}^{+}$and $\mathrm{Ca}^{2+}$ in SBF, leading to a higher apatite deposition rate [140]. The authors have discovered that varying $\mathrm{Rb}_{2} \mathrm{O}$ content had no significant effect on morphology, scale, shape, chemical composition, and structure of the sol-gel-derived BG [142]. Similarly, Rubidium-containing mesoporous bioactive glasses $(\mathrm{Rb}$ MBGs) shaped into scaffolds (80 $\mathrm{SiO}_{2}-(15-x) \mathrm{CaO}-5$
$\mathrm{P}_{2} \mathrm{O}_{5}-x \mathrm{Rb}_{2} \mathrm{O}$ with $x=0,1,2$, and 5 in mol\%) were shown to exhibit enhanced bioactivity and promoted osteogenesis and angiogenesis [142]. Biomimetic surface mineralization of Rb-MBG scaffolds was assessed in SBF immersion resulting in the formation of a nanostructured apatite phase on the surface upon contact with SBF for 3 days. In terms of proliferation and osteogenic differentiation of human mesenchymal stem cells, the ALP activity and expression of COL-1, VEGF HIF-1 $\alpha$, and Wnt/B-catenin signaling, significantly increased with $\mathrm{Rb}$ addition compared to $\mathrm{Rb}$-free MBG scaffolds [142]. Similarly, the antibiotic enoxacin (ENX) was loaded into Rb-MBG scaffolds to explore the ability of the constructs to act as drug delivery carriers and specifically to provide antibacterial effect [142]. It was found that $5 \mathrm{~mol} \% \mathrm{Rb}$-doped MBG (5Rb-MBG) scaffolds and ENX-loaded 5Rb-MBG scaffolds reduced the viability of Escherichia coli and S. aureus compared to bare MBG scaffolds [142]. Rb-doped bioactive glass nanospheres ( $\mathrm{Rb}$ BGNs) for skin regeneration and wound healing applications have been examined as alternative biomaterials for soft tissue regeneration [58]. He et al. [141] reported that BGNs with $\mathrm{Rb}$ content greater than $3 \mathrm{~mol} \%$ were toxic to HUVECs, fibroblasts, and HaCaTs cells, while BGNs with $\mathrm{Rb}$ contents less than or equal to $3 \mathrm{~mol} \%$ were nontoxic to the same cells. Interestingly, the ionic dissolution products of Rb-BGNs stimulated vascular tubule formation in contact with HUVECs through angiogenesis-related gene expressions such as HIF- $1 \alpha$ and VEGF, aided by growthpromoting molecules, for instance TGF- $\beta 1$, FGF2, PDGF, and EGF, as well as by triggering the ERK and P38 signaling pathways [141]. In vivo studies revealed that $\mathrm{Rb}$-BGNs loaded with EGF accelerated wound healing of rats and have potential as endothelial growth factor transport vehicles with high bioactivity [141].

\subsubsection{Barium (Ba)}

Barium is a trace element found in the human body $(22 \mathrm{mg}$ in a $70 \mathrm{~kg}$ adult) [143]. Most $\mathrm{Ba}$ is found in bones and smaller amounts are present in muscle, skin, connective tissue, and lungs. Similar to other elements, barium can enter the body through the air, food, and drinking water containing this element; however, the quantity of $\mathrm{Ba}$ in food and water is generally insufficient to cause health problems [143]. Dietary barium intake for adults has been reported in the range of $0.4-1.8 \mathrm{mg} /$ day and exposure to $3-4 \mathrm{~g}$ of $\mathrm{Ba}$ has been found toxic [144]. Clinically, barium sulfate is used in screening treatments and x-ray images [144] and in the last years, it has been considered as a therapeutic ion since it has shown stimulative effects on bioactivity, antibacterial, and anti-inflammatory properties in BGs [9, 63, 87, 145-158]. Majumdar et al. [9] synthesized nanoparticles of Ba-doped bioactive glass with composition 
$44.85 \mathrm{SiO}_{2}-2.6 \mathrm{P}_{2} \mathrm{O}_{5}-24.3 \mathrm{Na}_{2} \mathrm{O}-26.9 \mathrm{CaO}-1.35 \mathrm{BaO}(\mathrm{mol}$ $\%$ ) by sol-gel process. XRD analysis confirmed the amorphous nature of the bioactive glass containing $\mathrm{BaO} . \mathrm{Ba}^{2+}$ doping showed a positive effect on the bioactive behavior exhibiting the formation of HCA after immersion in SBF for 1 day. It was reported that $\mathrm{Ba}^{2+}$ (radius $=135 \mathrm{pm}$ ) replaced $\mathrm{Ca}^{2+}$ (radius $=100 \mathrm{pm}$ ) in the glass network, causing the glass network to become less rigid, resulting in a higher dissolution rate and faster ion release, enhancing bioactivity through the formation of hydroxyapatite. The cytocompatibility of Ba-containing BG and 45S5 BG as control was assessed using glioblastoma (C6 cells) and granulocytic 466 origin (K562) cells. Both Ba-containing BG and 45S5 BG enhanced proliferation in both cell lines without causing cytotoxicity. Moreover, in the same study, the ability of $\mathrm{Ba}^{2+}$ to prevent the lipopolysaccharideinduced amplification of interleukin-6 (IL-6), tumor necrosis factor- $\alpha$ (TNF- $\alpha$ ), and interleukin-10 (IL-10) was evaluated indicating the anti-inflammatory effect of this ion [9]. In another approach, Paliwal et al. [159] synthesized meltderived Ba-doped 45S5 BGs (1.3 BaO mol\%) and evaluated their effect on gastro-duodenal ulcers. After soaking in SBF on days 6 and 7, Ba-doped BGs exhibited higher $\mathrm{pH}$ values than 45S5 BG, indicating that Ba-containing BGs may have an enhanced antacid-like effect over 45S5 BG. In an in vivo study using a rat model, gastric ulcers were induced by various ulcerogens such as ethanol, aspirin, pyloric ligation, and acetic acid, besides duodenal ulcers were induced by cysteamine. BGs were suspended and administered at dose levels of $0.3,1.0$, and $3 \mathrm{mg} / \mathrm{kg}$. The results of the study revealed that Ba-BGs enhanced cell proliferation in the pyloric-induced gastric model and produced a protective layer on gastric and duodenum epithelium in the ethanolinduced gastric ulcer model. Furthermore, it was concluded that $\mathrm{Ba}-45 \mathrm{~S} 5 \mathrm{BGs}$ in the dose of $3 \mathrm{mg} / \mathrm{kg}$ prevented and healed gastric-duodenal ulcers induced by different ulcerogens [159]. For cancer hyperthermia applications, the combination of magnetic properties and bioactive behavior of $\mathrm{Ba}$-containing $\mathrm{BGs}$ is gaining attention. Yazdanpanah et al. [154] investigated a $\mathrm{CaO}-\mathrm{P}_{2} \mathrm{O}_{5}-\mathrm{SiO}_{2}-\mathrm{BaO}-\mathrm{Fe}_{2} \mathrm{O}$ magnetic sol-gel-derived $\mathrm{BG}$ system. Apatite layer deposition on the glass surface was influenced by the addition of $\mathrm{Ba}$ and $\mathrm{Fe}$ to the glass composition (0-10 mol\% of $\mathrm{BaO}$ and $0-15 \mathrm{~mol} \%$ of $\mathrm{Fe}_{2} \mathrm{O}_{3}$ ). Bioactivity improved when $\mathrm{BaO}$ content increased; however, it declined as $\mathrm{Fe}$ concentrations increased. In addition, the Ba-containing BG was nontoxic to L929 mouse fibroblast cells. In another application, Zakaly et al. [160] investigated the nuclear radiation attenuation features of borosilicate glasses doped with barium as radiation shielding material. The meltquenching technique was used to produce $\mathrm{BGs}$ with base composition: $50 \mathrm{~B}_{2} \mathrm{O}_{3}-20 \mathrm{NaO}-15 \mathrm{SiO}_{2}-10 \mathrm{CaO}-5 \mathrm{Al}_{2} \mathrm{O}_{3}$ (in wt.\%) and increasing $\mathrm{BaO}$ content; from 0 to $30 \mathrm{wt} . \%$.
The density and hardness improved with increasing $\mathrm{BaO}$ content. XRD analysis confirmed that the incorporation of $\mathrm{BaO}$ did not affect the amorphous structure of the glasses. Furthermore, specific material features such as mass attenuation coefficient (MAC), linear attenuation coefficient $(\mathrm{LAC})$, mean free path $(\lambda)$, and half-value layer $(\mathrm{X} 1 / 2)$ can be used to study the effective radiation shielding of materials. When $30 \mathrm{wt} . \% \mathrm{BaO}$ was incorporated in the glass, the glass density increased (from 2.673 to $3.652 \mathrm{~g} / \mathrm{cm}^{3}$ ) resulting in lower $\lambda$ and X1/2 values, as well as higher MAC and LAC, indicating that there was a superior gamma shielding and enhanced transmission and optical bandgap. Highdensity glasses resulted in higher effective shielding than low-density glasses [160].

\subsection{Transition metals}

\subsubsection{Tantalum (Ta)}

Ta has been known as a biocompatible metal with superior properties in terms of corrosion resistance and bioactivity, consequently it has been considered for surgical implants [161]. The addition of tantalum to bioactive glasses has been reported in different investigations [151, 162-172]. Silicate bioactive glasses produced by sol-gel in the system $58 \mathrm{SiO}_{2}-37 \mathrm{CaO}-5 \mathrm{P}_{2} \mathrm{O}_{5}$ (mol\%) doped with $0.2-1 \mathrm{~mol} \%$ tantalum pentoxide $\left(\mathrm{Ta}_{2} \mathrm{O}_{5}\right)$ revealed a rapid in vitro acellular HCA deposition $(6 \mathrm{~h})$ after soaking in SBF. Doping with tantalum improved the ability of glasses to develop apatite-like structures at concentrations $0.2-0.6 \mathrm{~mol} \%$, but a retarding effect at higher Ta concentrations $(0.8$, and $1 \mathrm{Ta}$ mol\%.) was found. These glasses also showed an antibacterial effect against $S$. aureus and E. coli; these properties make Ta a promising therapeutic dopant in bioactive glasses for bone tissue engineering [173]. Nagrath et al. [162] reported the hemostatic properties of Ta-doped MBGs of composition $80 \mathrm{SiO}_{2}-15 \mathrm{CaO}-5 \mathrm{P}_{2} \mathrm{O}_{5}$ (mol\%), in which various $\mathrm{Ta}_{2} \mathrm{O}_{5}$ concentrations were analyzed from 0 to $10 \mathrm{~mol} \%$. Ta supplementation showed hemostatic potential due to its negative zeta potential ( -23 to $-31 \mathrm{mv}$ ), which enhanced the intrinsic mechanism of blood plasma coagulation and promoted hemostasis by decreasing the active partial thromboplastin and prothrombin times. According to cytotoxicity evaluation, Ta-MBGs (Ta concentration of $0,0.5,1$, and $5 \mathrm{~mol} \%$ ) did not have a negative effect on the viability of bovine fibroblast cells [162]. Moreover, the in vitro bioactivity and cytocompatibility of Ta-doped borosilicate BGs have also been reported [174], concluding that the addition of Ta from 0.5 to $3 \mathrm{~mol} \%$ in borosilicate BGs had an influence on the bioactive behavior, resulting in lower bioactivity for higher concentrations of Ta ( $3 \mathrm{~mol} \%)$, without affecting cell viability (MG 63 cells). 


\subsubsection{Zirconium (Zr)}

Zirconium as zirconium oxide has been used in the biomedical field for dental [175] and bone implants due to its superior mechanical properties and cytocompatibility [176-195]. Enhancement in mechanical stability and hydroxyapatite formation in silicate, borate, and phosphate bioactive glasses has been observed by incorporating zirconium [183, 196-198]. Yadav et al. [197] reported that the addition of zirconium (up to $2.0 \mathrm{wt} . \%$ ) in 13-93 bioactive glass resulted in a significantly faster dissolution rate and a higher $\mathrm{pH}$ of SBF solution dependent on the zirconium concentration. In order to facilitate bone tissue engineering, suitable mechanical properties of the scaffold materials are important. As reported by Kumar et al. [183], compressive strength values increased from $10 \pm 2$ to $19+2 \mathrm{MPa}$ when $\mathrm{ZrO}_{2}$ nanoparticle content was increased from 0 to $0.2 \mathrm{~g}$ in $56 \mathrm{SiO}_{2}-34 \mathrm{CaO}-10$ $\mathrm{P}_{2} \mathrm{O}_{5}(\mathrm{~mol} \%)$ bioactive glass scaffolds, leading to the formation of $\mathrm{ZrSiO}, \mathrm{ZrSiO}_{4}, \mathrm{Zr}_{2} \mathrm{O}\left(\mathrm{PO}_{4}\right)$, and $\mathrm{Ca}\left(\mathrm{ZrO}_{3}\right)$ crystalline phases. These values are comparable to the compressive strength of human cancellous bone, which ranges from 1.5 to $45 \mathrm{MPa}$ [199]. By raising $\mathrm{ZrO}_{2}$ concentration to $5 \mathrm{wt} \%$, the microhardness of melt-derived borosilicate bioactive glass $\left(\begin{array}{llll}31 & \mathrm{~B}_{2} \mathrm{O}_{3}-20 & \mathrm{SiO}_{2}-24.5\end{array}\right.$ $\mathrm{Na}_{2} \mathrm{O}-24.5 \mathrm{CaO}$ mol\%) improved from 5.45 to $6.17 \mathrm{GPs}$, while the apatite-formation ability decreased [188]. $\mathrm{ZrO}_{2}$ has been shown to display strong antibacterial properties. According to Kumar et al. [183], Zr-BG scaffolds showed antibacterial activity against $S$. aureus, E. coli, and Pseudomonas aeruginosa, but only a weak effect on Bacillus subtilis. The biological behavior of $\mathrm{Zr}$-containing $3 \mathrm{D}$ scaffolds with composition $60 \mathrm{SiO}_{2}-36 \mathrm{CaO}-4 \mathrm{P}_{2} \mathrm{O}_{5}$ mol\% (58S BG) was investigated by Moghanian et al. [198]. After incubation for 7 and 14 days, 3D-porous 58S BG scaffolds containing $0-10 \mathrm{~mol} \% \quad \mathrm{ZrO}_{2}$ stimulated MC3T3-E1 cell adhesion on the scaffold and enhanced cell proliferation at more prolonged periods of incubation. The ALP activity of MC3T3-E1 cells increased with the presence of $\mathrm{ZrO}_{2}$ in the $58 \mathrm{BG}$ scaffold at all time points. Interestingly, the glass containing $5 \mathrm{~mol} \% \mathrm{Zr}$ showed the highest ALP activity compared to the other BGs [198]. The non-cytotoxic effect of zirconium-doped bioactive glass (5-15 wt.\% of nano $\mathrm{ZrO}_{2}$ powder) as thin film coatings on $\mathrm{Cp}$-Ti substrates has also been investigated on MG 63 osteoblast cells [200]. Moreover, a recent study reported the advantages of 13-93 bioactive glass doped with zirconium $(2 \mathrm{~mol} \%)$ and silver oxide. Co-doping with $\mathrm{Zr}$ and $\mathrm{Ag}$ in 13-93 BG improved cytocompatibility of U2OS cells, antibacterial effects against B. subtilis and $E$. coli, and led to mechanical properties enhancement in terms of compression strength, elastic modulus, and flexural strength [201].

\subsubsection{Niobium (Nb)}

Therapeutic niobium ions have been shown to play an influencing role in bioactivity, biocompatibility, and mechanical properties of bioactive glasses and bioceramics for regenerating bone tissue [202-228]. Bioactive borosilicate glass $\left(31 \mathrm{~B}_{2} \mathrm{O}_{3}-20 \mathrm{SiO}_{2}-24.5 \mathrm{Na}_{2} \mathrm{O}-24.5 \mathrm{CaO}\right.$ mol $\%$ ) doped with niobium (Nb-borosilicate $\mathrm{BG}$ ) has shown in vitro bioactivity in terms of hydroxyapatite forming ability when soaked in SBF solution after 7 days, exhibiting no cytotoxic effect on MG 63 cells. The ability to form an apatite layer and support cell viability was unaffected by different concentrations of $\mathrm{Nb}_{2} \mathrm{O}_{5}$ (0-10 mol\%) [229]. Nevertheless, the bioactivity of $\mathrm{Nb}$-doped $\mathrm{BG}$ needs further investigation. Lopes et al. [230] investigated 45S5 BG with 2.5 and $5 \mathrm{~mol} \%$ concentrations of $\mathrm{Nb}_{2} \mathrm{O}_{5}$, which showed a delayed formation of $\mathrm{HCA}$ on the $\mathrm{BG}$ surface compared to both 45S5 BG and 1 mol\% $\mathrm{Nb}_{2} \mathrm{O}_{5}$-doped 45S5 BG.

The presence of niobium in bioactive glasses could also promote osteogenic and angiogenic properties. In vitro cell studies have shown the cytocompatibility, osteostimulation, and osteoinduction of Nb-doped 45S5 BG [230]. In this study, Nb-substituted glasses had no negative effect on bone marrow-derived mesenchymal stem cells (BMSCs). Moreover, osteogenic differentiation of BMSCs was induced at concentrations of 1 and $2.5 \mathrm{~mol} \% \mathrm{Nb}_{2} \mathrm{O}_{5}$ in $45 \mathrm{~S} 5$ BG after 21 days using a glass concentration of $10 \mathrm{mg} / \mathrm{ml}$ [230].

In similar research, Miguez-Pacheco et al. [231] observed the in vitro behavior of ST-2 cells in RPMI medium exposed to extracts of $45 \mathrm{~S} 5 \mathrm{BG}$ containing $\mathrm{Nb}_{2} \mathrm{O}_{5}$ (0-1 mol\%) powders. The results showed that the higher tested concentration of $10 \mathrm{mg} / \mathrm{ml}$ was toxic to cells, while 1 and $0.1 \mathrm{mg} / \mathrm{ml}$ concentrations did not show a negative effect on cells. When compared to undoped 45S5 BG, different $\mathrm{Nb}$ contents did not show significant effects on cell viability at low concentrations $(0.1$ and $1 \mathrm{mg} / \mathrm{ml})$. On the other hand, at lower concentrations, there was a significant release of VEGF from ST-2 cells, indicating the potential angiogenic effect of Nb-BG. Furthermore, in vivo studies [232-234] showed the osteoestimulative potential of $\mathrm{Nb}$-doped bioactive glass for bone replacement. Figure 4 illustrates the subperiosteal bone region growth promoted by $\mathrm{Nb}-45 \mathrm{~S} 5$ BG (46.1 $\mathrm{SiO}_{2}-26.9 \mathrm{CaO}-24.4 \mathrm{Na}_{2} \mathrm{O}-1.3 \mathrm{P}_{2} \mathrm{O}_{5}-1.3 \mathrm{Nb}_{2} \mathrm{O}_{5}$ mol.\%) cylindrical rods after 28 days of implantation into a defect in rat calvaria with dimensions of $4 \mathrm{~mm}$ length and $2 \mathrm{~mm}$ diameter [232]. Similarly, Fig. 5 shows fully bone regeneration in a $5 \mathrm{~mm}$ rat calvarial defect after 8 weeks of implantation. In this study, a higher amount of $\mathrm{Nb}$ compared to the previous investigation was used $\left(2.6 \mathrm{Nb}_{2} \mathrm{O}_{5}\right)$ [233]. Phosphate-based glasses-containing $\mathrm{Nb}$ have also been reported by Obata et al. [235, 236]. The biological properties of $\mathrm{Nb}$-containing phosphate BGs (3 and $5 \mathrm{~mol} \%$ 
a)

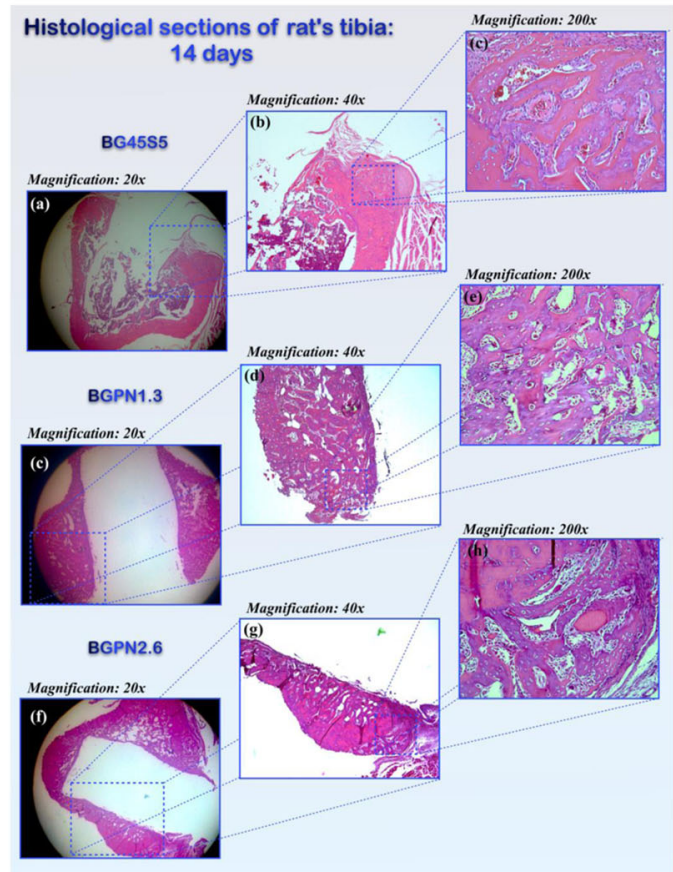

Fig. 4 In vivo implantation of Nb-containing 45S5 BG rods: a subperiosteal new bone formation in rat tibia tissue defect after 28 days of implantation, hematoxylin \& eosin staining, b growth area of

$\mathrm{Nb}_{2} \mathrm{O}_{5}$ in the composition $60 \mathrm{CaO}-30 \mathrm{P}_{2} \mathrm{O}_{5}-10 \mathrm{Na}_{2} \mathrm{O}$ in mol\%) demonstrated higher ALP activity for Nb-BGs compared to $\mathrm{Nb}$-free phosphate $\mathrm{BG}$ as well as an influencing effect on differentiation and mineralization dependent on $\mathrm{Nb}$ concentration [236]. The incorporation of higher amounts of $\mathrm{Nb}_{2} \mathrm{O}_{5}(0-60 \mathrm{~mol} \%)$ in phosphate glasses has also been investigated [237]. Lima et al. [219] studied in vivo the effect of $30 \mathrm{~mol} \% \mathrm{Nb}_{2} \mathrm{O}_{5}$ in the system $\mathrm{P}_{2} \mathrm{O}_{5}-\mathrm{BaO}-\mathrm{K}_{2} \mathrm{O}$ after the implantation of granules in a rat model. After 3 and 9 weeks of implantation the authors reported blood vessel formation and no fibrous capsules around the granules.

\subsubsection{Chromium (Cr)}

Chromium is one of the essential elements in the human body. It has a biological role that influences the activity of insulin receptors [238]. Furthermore, chromium is one of the major trace elements regulating blood sugar and lipid levels in the body [239]. Recent reports indicate that an intake of $120 \mu \mathrm{g}$ of chromium per day is sufficient for adults to preserve their health [240]. Toxic daily doses exceed $200 \mu \mathrm{g}$ [240]. In bioactive glasses and bioceramics, chromium has shown promising effects by enhancing bioactivity, antibacterial activity, and degradation properties [241]. Krishnamacharyulu et al. [241] investigated a chromiumdoped calcium borosilicate glass produced via the b)

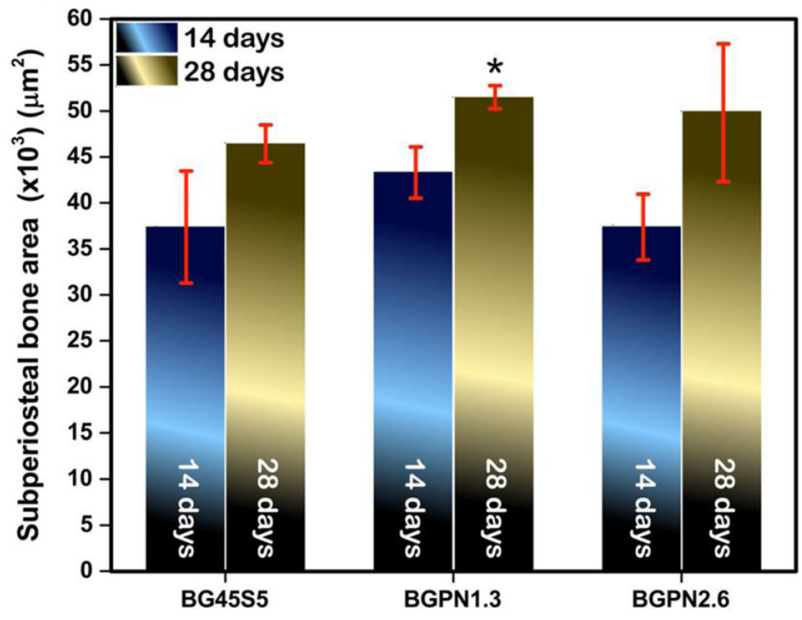

subperiosteal bone in rats treated at different times [232]. Reproduced according to Creative Commons license (CC BY 4.0)

conventional melt-quenching method with composition 43 $\mathrm{B}_{2} \mathrm{O}_{3}-5 \mathrm{SiO}_{2}-2 \mathrm{P}_{2} \mathrm{O}_{5}-20 \mathrm{Na}_{2} \mathrm{O}-20 \mathrm{CaO}$ (mol\%). Varying concentrations of chromium oxide, ranging from 0 to $1 \mathrm{~mol}$ $\%$, were incorporated in the BG. It was reported that the presence of $\mathrm{Cr}_{2} \mathrm{O}_{3}$ as a network modifier changed the structure of the glass by breaking the network bonds and causing the formation of non-bridging oxygen. Furthermore, the increment of $\mathrm{Cr}_{2} \mathrm{O}_{3}$ concentrations enhanced chromium ions transfer from tetrahedral chromates $\left(\mathrm{CrO}_{4}{ }^{2-}\right)$ to octahedral chromates $\left(\mathrm{CrO}_{6}\right)$, reducing the glass strength. The degradation rate of the glass in SBF increased for higher contents of $\mathrm{Cr}_{2} \mathrm{O}_{3}$ due to octahedral chromates positions. The substitution of $\mathrm{Cr}_{2} \mathrm{O}_{3}$ with $\mathrm{CaO}$ led to apatite formation in SBF solution after 28 days. Furthermore, the intensity of the XRD peak corresponding to HA increased as the $\mathrm{Cr}_{2} \mathrm{O}_{3}$ concentration increased. Hence, with an increase in the $\mathrm{Cr}_{2} \mathrm{O}_{3}$ content, the $\mathrm{BG}$ exhibited a superior bioactive behavior. The authors concluded that a high concentration of $\mathrm{Cr}_{2} \mathrm{O}_{3}(1 \mathrm{~mol} \%)$ promoted greater $\mathrm{BG}$ degradation and in vitro bioactivity.

\subsubsection{Molybdenum (Mo)}

Molybdenum is a trace element required for several enzymes such as xanthine oxidoreductase, sulfite oxidase, and mitochondrial amidoxime reductase, being important for the metabolism of purines, sulfur-containing aminoacids, conversion of 
Fig. 5 Microcomputed tomography images showing bone regeneration in a 5-mm critical-size defect in rat calvaria after 56 days [233]. Reproduced with permission from John Wiley and Sons

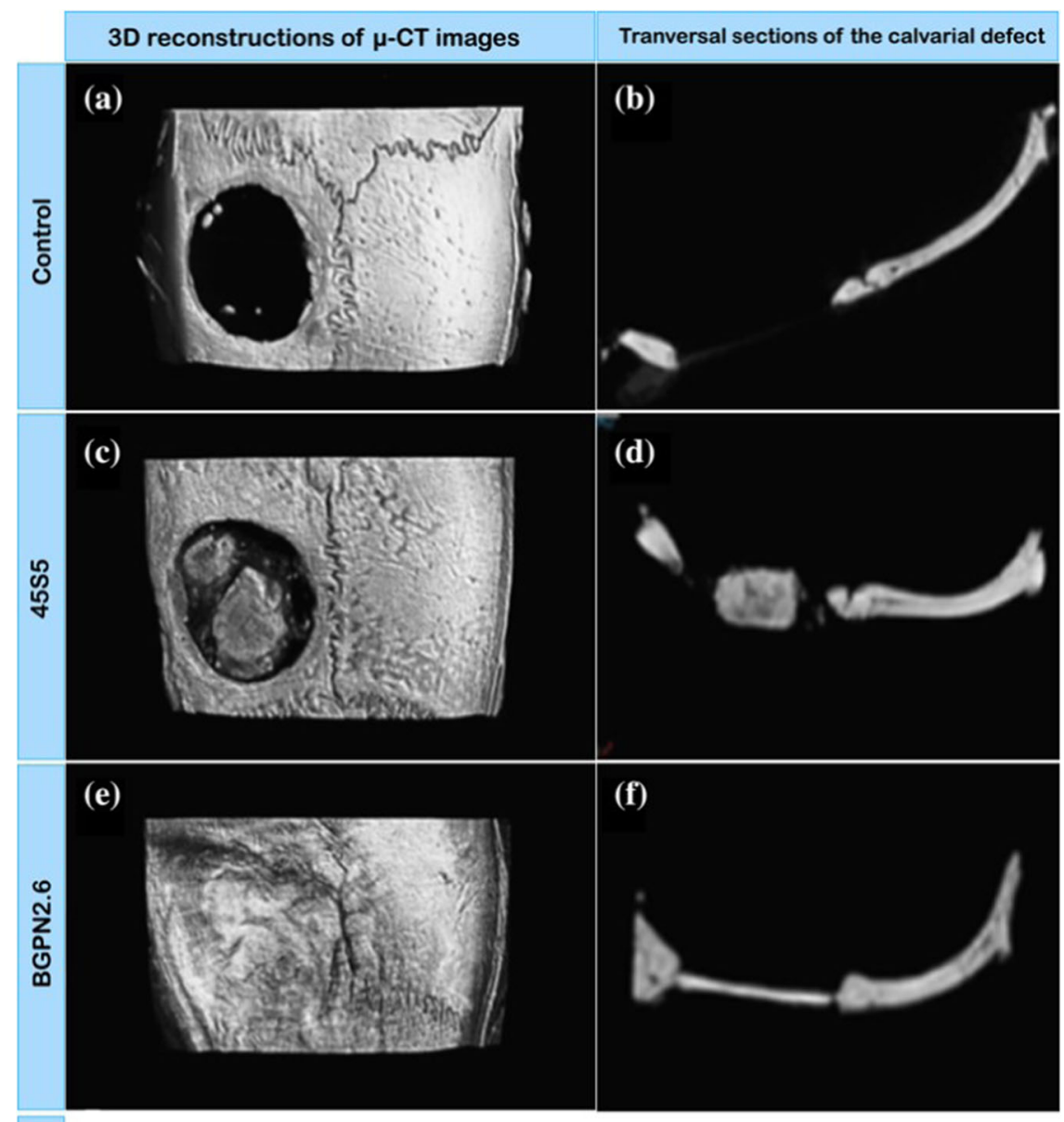

(g) Percentage of bone within the defect after 56 days of implant
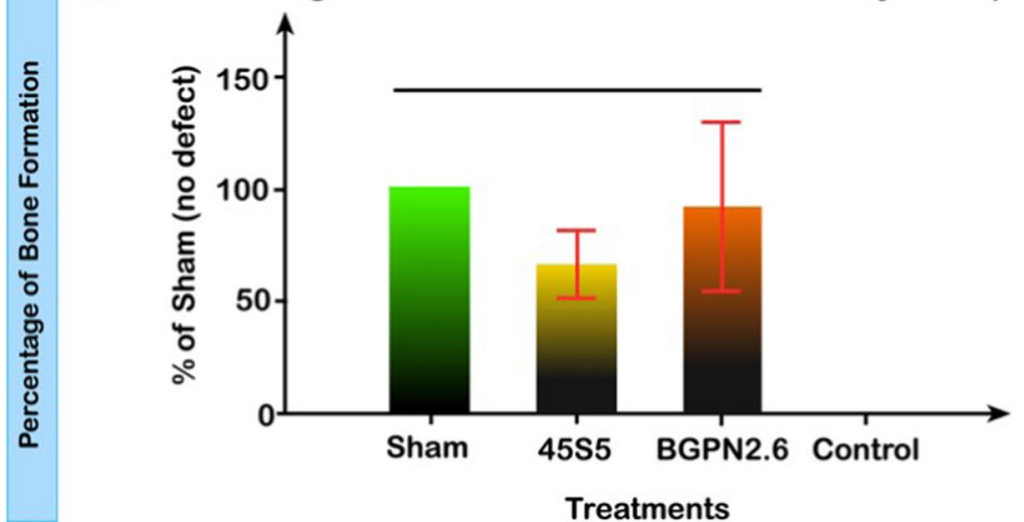

aldehides to acids, protein synthesis stimulation, and body growth [242-245]. In the human body, molybdenum is found primarily in the adrenal glands, bones, liver, and kidneys [246]. For biomedical applications, Mo-containing biomaterials are attracting attention due to their antibacterial and anticancerogenic properties [245, 247-254]. According to Ponta et al. [255], Mo-containing sol-gel derived $\mathrm{SiO}_{2}-\mathrm{CaO}-\mathrm{P}_{2} \mathrm{O}_{5}$ BGs have potential for applications in bone tissue engineering by stimulating in vitro apatite formation in SBF solution after 10 days. $\mathrm{MoO}_{3}$ in the range of $3-10 \mathrm{~mol} \%$ has been added and the influence of Mo on bioactivity and biocompatibility of the BGs was investigated. XRD patterns of Mo-doped BG calcined at $600{ }^{\circ} \mathrm{C}$ confirmed the presence of hydroxyapatite and calcium molybdate $\left(\mathrm{CaMoO}_{4}\right)$ nanocrystals. Moreover, in vitro biological assays indicated that crystalline $\mathrm{CaMoO}_{4}$ phases led to improved biocompatibility by increasing adsorption of bovine serum albumin without hindering the formation of hydroxyapatite. The authors concluded that a $5 \mathrm{~mol} \% \mathrm{MoO}_{3}$ substitution resulted in enhanced bioactivity and biocompatibility [255]. Similarly, Dang et al. [256] investigated the 
influence of $\mathrm{MoO}_{3}$ on bioactive glass-ceramic (Mo-BGC) scaffolds for bone/interface applications using silicate glasses of composition $70 \mathrm{SiO}_{2}-25 \mathrm{CaO}-5 \mathrm{P}_{2} \mathrm{O}$ (mol\%) with 2,5 , and $7.5 \mathrm{~mol} \%$ of $\mathrm{MoO}_{3}$ substituted for $\mathrm{CaO}$. The sol-gel method and $3 \mathrm{D}$ printing technology were used to fabricate the Mo$\mathrm{BGC}$ scaffolds. The findings indicated that the addition of Mo to BGC scaffolds increased the compressive strength due to the formation of $\mathrm{CaMoO}_{4}$ phase during the calcination process of Mo-BGC powder at $800^{\circ} \mathrm{C}$. In vitro degradation in Tris- $\mathrm{HCl}$ buffer solution of Mo-BGC scaffold resulted in a lower weight loss compared to Mo-free scaffolds. Furthermore, the rate of release of Mo ions from the scaffolds was evaluated in Tris$\mathrm{HCl}$ solution for up to 28 days. A gradual release was observed during the incubation time dependent on the Mo concentration. The release profiles did not show a final time point; therefore, after 28 days, Mo was still being released from all Mo-doped scaffolds. Moreover, in vitro cell experiments demonstrated that crushed scaffolds with $7.5 \mathrm{~mol} \%$ of $\mathrm{MoO}_{3}$ at a concentration of $25 \mathrm{mg} / \mathrm{ml}$ increased chondrogenic differentiation of rabbit chondrocytes (RCs) and osteogenic differentiation of hBMSCs at days 3 and 7 when compared to Mo-free BGC. Interestingly, in vivo studies in rabbit osteochondral defects for 8 and 12 weeks showed that BGC scaffolds with $7.5 \mathrm{~mol} \%$ $\mathrm{MoO}_{3}$ considerably enhanced cartilage/bone regeneration, demonstrating bi-lineage bioactivity [256]. Furthermore, Mocontaining phosphate-based glasses have also been investigated. For example, Lucacel et al. [257] reported the bioactivity and biocompatibility of melt-derived $48 \mathrm{P}_{2} \mathrm{O}_{5}-45 \mathrm{CaO}-5$ $\mathrm{K}_{2} \mathrm{O}-2 \mathrm{~B}_{2} \mathrm{O}_{3}$ (mol\%) glass containing $1,3,5$, or $7 \mathrm{~mol} \%$ of $\mathrm{MoO}_{3}$. XRD analysis confirmed the amorphous structure of the BGs with different amounts of Mo. The capability of HA formation of the glasses was evaluated in SBF for 15 days. In contrast to the Mo-free glass, no HA crystalline phase on the surface of molybdenum-doped calcium phosphate-based glass was detected, this might be due to the formation of dominant $\mathrm{Mo}^{5+}$ ionic species on the surface inhibiting the migration of calcium and phosphate ions to the glass surface. Phosphate BGs containing molybdenum at 5 and $7 \mathrm{~mol} \%$ exhibited biocompatibility and low toxicity to $\mathrm{HaCaT}$ cells [257]. In drug delivery applications, molybdenum oxide has been used to modify the network of phosphate glasses in order to control the degradation rate. El-Meliegy et al. [258] investigated meltderived phosphate glasses $\left(50 \mathrm{P}_{2} \mathrm{O}_{5}-30 \mathrm{CaO}-20 \mathrm{Na}_{2} \mathrm{O}, \mathrm{mol} \%\right)$ incorporating $\mathrm{MoO}_{3}$ (from 5 to $10 \mathrm{~mol} \%$ ) to tune glass dissolution and drug release. The dissolution rate in Tris- $\mathrm{HCl}$ buffer solution of phosphate glass-containing molybdenum was lower than the one of the reference phosphate glass without Mo due to the high valence of Mo oxide, which improves the bonding strength in the glass network. The surface of Mo-free phosphate glasses exhibited calcium phosphate deposits after 7 days of immersion in SBF; however, this was not the case for the Mo-doped glasses (5 and $10 \mathrm{~mol} \%$ ). Moreover, Mocontaining BGs have shown lower Vancomycin release rates than Mo-free phosphate glass, which the authors attributed to the hydrogen interactions between the hydroxyl and aminofunctional groups in the drug and the hydrated $\mathrm{P}-\mathrm{O}-\mathrm{H}$ groups in the phosphate glass network [258].

\subsubsection{Vanadium (V)}

Vanadium is a trace element related to nutritional and biochemical functions in humans, animals, and plants [259]. Daily consumption of $10 \mathrm{mg}$ of vanadium per kilogram of body mass has been reported to not have negative effects on human health [260]. Biological properties of V include the ability to stimulate insulin synthesis and mimic the effects of growth factors and biomarkers for bone-forming cell differentiation [259, 261]; therefore, vanadium has been considered in BGs in various studies [253, 262-265]. Vanadium-containing borate-based bioactive glass (13-93B3 with $0.15-3$ wt.\% V) scaffolds have been investigated for bone tissue engineering applications [266]. Vanadium was reported to act as a network modifier in the 13-93B3 glass system, leading to a faster degradation in SBF solution under static conditions by inhibiting tetrahedral $\mathrm{BO}_{4}$ units formation. Moreover, 3 wt.\% V-substituted 13-93B3 scaffolds exhibited crystalline HA after 20 days of immersion in SBF [266]. Similarly, in another study, Marzouk et al. [267] reported the bioactivity of V-containing borate glass $\left(57.5 \mathrm{~B}_{2} \mathrm{O}_{3}-17 \mathrm{CaO}-5.5\right.$ $\mathrm{Na}_{2} \mathrm{O}-11 \mathrm{~K}_{2} \mathrm{O}-4.5 \mathrm{MgO}-4.5 \mathrm{P}_{2} \mathrm{O}_{5}$ in wt.\% with $0.5-1$ wt. $\% \mathrm{~V})$ after immersion in phosphate solution for 14 days. Furthermore, Deliormanli et al. [268] investigated in vivo the capacity of vanadium incorporated borate-based BG scaffolds for soft tissue applications using a mouse subcutaneous implantation set-up. After implantation for 4 weeks, fibrous connective tissue infiltrated inside V-containing scaffolds. As the concentration of vanadium increased to $3 \mathrm{wt} . \%$, a reduction of tissue filtration was observed. In addition, V-containing scaffolds (3 wt.\%) were reported to have a negative effect on angiogenesis by decreasing the vascularization area compared to V-free 13-93B3 BG scaffolds. Furthermore, according to a recent study, V-doped borate-based 13-93B3 BGs have also shown potential to be used in medical radiation applications and luminescence bioimaging [269, 270].

$\mathrm{Li}$ et al. [271] used the hydrothermal synthesis technique to dope $\mathrm{MBG}$ in the system $\mathrm{SiO}_{2}-\mathrm{CaO}-\mathrm{P}_{2} \mathrm{O}_{5}$ with vanadium in various concentrations $(0,0.71,2.78$, and $6.67 \mathrm{~mol}$ $\%)$ with a triblock copolymer (P123) as the structuredirecting agent. The aim of the study was to modify the morphology and mesostructure of V-doped MBG to optimize the glass dissolution and biological behavior. Vanadium concentration significantly influenced the morphology and mesostructure of V-doped MBG. The mesopore size, total pore volume, specific surface area, wall thickness, total 
micropore volume, and ordered mesostructure decreased significantly at increasing $\mathrm{V}$ content due to the presence of vanadate anions in solution, that could change the P123 micellization and self-assembly behavior by inducing salting-in and acidity-down effects, as well as three different forms of vanadium species located at the pore walls and/or the surface of the MBG. Clearly, the number of studies on $\mathrm{V}$-containing BGs is very limited and, therefore, the potential biological benefits of $\mathrm{V}$ in conjunction with BGs should be further investigated in systematic studies, considering also different silicate glass compositions.

\subsubsection{Manganese (Mn)}

$\mathrm{Mn}$ is an essential trace element, which is required for the growth, development, and maintenance of healthy bones; a lack of this element in the pre-natal and early post-natal stages has been reported to cause skeletal abnormalities [272]. Bioactive glasses containing Mn have been investigated due to the properties provided by this ion, such as bioactivity, biocompatibility, and antibacterial effects [273281]. Miola et al. [282] reported the incorporation of $\mathrm{Mn}$ in a melt-derived silicate $\mathrm{BG}\left(45 \mathrm{SiO}_{2}-3 \quad \mathrm{P}_{2} \mathrm{O}_{5}-26 \mathrm{CaO}-7\right.$ $\mathrm{MgO}-15 \mathrm{Na}_{2} \mathrm{O}-4 \mathrm{~K}_{2} \mathrm{O}$ ) substituting the molar ratio of $\mathrm{MgO}$ by $\mathrm{MnO}$ in the range of $0.25-0.5 \%$. In vitro bioactivity tests in SBF revealed that Mn-doped BG showed HA formation on the surface after 28 days. Moreover, the effect of Mndoped BG on human MG 63 cells was also evaluated, indicating that $0.25-0.5 \mathrm{~mol} \% \mathrm{MnO}$ did not show any toxic effect within 5 days of incubation. Furthermore, $\mathrm{Mn}^{2+}$ has been shown to promote osteogenic gene expression described by the enhancement in ALP activity, type I collagen, osteocalcin, bone morphogenetic proteins, and soluble intercellular adhesion molecule-1 (sICAM-1) in osteoblasts. Since Mn-doped BGs have been shown to stimulate cell proliferation, cellular differentiation, and bioactivity, they are promising materials for bone tissue regeneration. In a different approach, Cañaveral et al. [283] investigated Mn-doped 58S sol-gel-based BG in which $\mathrm{CaO}$ was replaced by $\mathrm{MnO}(3-5 \mathrm{~mol} \%)$. After calcination at $700{ }^{\circ} \mathrm{C}$, the presence of $\mathrm{Mn}^{2+}$ significantly influenced the structure of 58S BG. XRD analysis revealed the presence of crystalline phases such as $\mathrm{Ca}_{3} \mathrm{Mn}_{2} \mathrm{Si}_{3} \mathrm{O}_{12}, \mathrm{CaSiO}_{3}-\mathrm{MnSiO}_{3}$, and $\mathrm{CaSiO}_{3}$ in Mn-doped BG while Mn-free 58S BG exhibited an amorphous structure. However, the crystallization of the Mn-doped BG did not have a negative effect on bioactivity since the presence of $\mathrm{Mn}^{2+}$ increased apatite formation after 2 days in SBF comparable with bare $58 \mathrm{~S}$ BG. Similarly, Barrioni et al. [284] doped 58S sol-gel BG with $\mathrm{Mn}^{2+}$ and evaluated the influence of the doping ion on the osteogenic cell differentiation capability and cytotoxicity of $58 \mathrm{~S}$ BG. Interestingly, in contrast to the results previously described, XRD analysis indicated amorphous glasses with and without $\mathrm{Mn}^{2+}$ from 2.5 to $5 \mathrm{~mol} \%$. Furthermore, MTT assays confirmed that the dissolution products of Mn-doped glass $(100-10,000 \mu \mathrm{g} / \mathrm{ml})$ were not cytotoxic for osteoblast cells (for $72 \mathrm{~h}$ ). Moreover, the antibacterial activity against $B$. subtilis, $P$. aeruginosa, and $S$. aureus of sol-gel Mn-doped BG $\left(0-7 \mathrm{~mol} \% \mathrm{MnO}_{2}\right)$ was demonstrated in other studies by Nawaz et al. [285]. Westhauser et al. [286, 287] reported the biological evaluation of sol-gel derived mesoporous bioactive glass nanoparticles (MBGNs) doped with $5 \mathrm{~mol} \% \mathrm{MnO}_{2}$. In vitro experiments using BMSCs demonstrated that MBGN with $5 \mathrm{~mol} \%$ $\mathrm{MnO}_{2}$ enhanced osteogenic differentiation by upregulating ALP, osteocalcin, osteopontin, and collagen $\alpha 1$ at a concentration of $1 \mathrm{mg} / \mathrm{ml}$, although lower cell viability was reported at the same tested concentration. In summary, MBGNs with $5 \mathrm{~mol} \% \mathrm{MnO}_{2}$ showed a significant cytotoxic effect at days 14 and 21. On the other hand, Mn containing MBGN at a concentration of $0.1 \mathrm{mg} / \mathrm{ml}$ increased cell viability from day 7 and did not show any cytotoxicity effect, demonstrating the dose-dependent effect of this material on cell behavior. Furthermore, phosphate-based BGs prepared via sol-gel synthesis $\left(20 \mathrm{Na}_{2} \mathrm{O}-15 \mathrm{CaO}-5 \mathrm{~B}_{2} \mathrm{O}_{3}-5 \mathrm{SiO}_{2}-55\right.$ $\mathrm{P}_{2} \mathrm{O}_{5}$ ) with $0-1 \mathrm{~mol} \%$ of $\mathrm{MnO}_{2}$ have been reported by Bragiel et al. [288]. In vitro bioactivity in SBF showed apatite formation on the glass surface after 7 days. A larger radius of $\mathrm{Mn}^{2+}$ compared to $\mathrm{Ca}^{2+}$ led to a faster network degradation of $\mathrm{Mn}$-doped glasses, leading to a faster apatite mineralization in SBF. No cell biology studies have been reported on such phosphate Mn-BGs.

\subsubsection{Gold (Au)}

Gold has been incorporated in BGs to explore the enhancement of features for drug delivery, wound healing, photothermal therapy, and bone regeneration [289-304]. Sol-gel BGs doped with gold nanoparticles (AuNPs) $(60$ $\mathrm{SiO}_{2}-32 \mathrm{CaO}-8 \mathrm{P}_{2} \mathrm{O}_{5}$ mol\% with $0-0.2 \mathrm{~mol} \% \mathrm{Au}_{2} \mathrm{O}$ ) have been studied by Magyari et al. [305]. XRD patterns indicated Au crystalline phases, while no crystalline peaks were detected in the Au-free BGs. The presence of AuNPs in the BGs significantly affected the in vitro bioactivity and biocompatibility. AuNPs-doped BGs exhibited apatite layer formation after immersion in SBF for 7 days. The morphology of apatite-like structures on the BGs surface was shown to be dependent on the amount of AuNPs, resulting in both spherical and flower-like shapes $\left(0.2 \mathrm{~mol} \% \mathrm{Au}_{2} \mathrm{O}\right)$. Furthermore, BGs with 0.15 and $0.2 \mathrm{~mol} \% \mathrm{Au}_{2} \mathrm{O}$ promoted the proliferation of human keratinocyte cells. Similarly, Grandi et al. [306] synthesized 58S BG doped with AuNPs (0.1 and $1 \mathrm{wt} . \%)$. Interestingly, the antibacterial properties against $S$. aureus of the reference 58S BG were enhanced by the presence of $\mathrm{Au}$, while no enhancing effect was observed against $E$. coli. 


\subsubsection{Nickel (Ni)}

Nickel has been incorporated in BGs to improve properties related to radiation attenuation and bone regeneration [307312]. Vyas et al. [313-315] developed 45S5 BG and 45S5 BG-ceramic (BGC) doped with $\mathrm{NiO}$ at different concentrations ranging from 0.41 to $1.65 \mathrm{~mol} \%$ via the meltquenching route. Compared to $\mathrm{Ni}$-free $45 \mathrm{~S} 5 \mathrm{BGCs}$, an increase in density and mechanical properties such as microhardness, compressive, and flexural strength was observed with increasing $\mathrm{NiO}$ concentration $[313,315]$. The incorporation of $\mathrm{Ni}$ did not have an effect on the amorphous structure of 45S5 BG, as well as no additional crystalline phases were observed for the glass-ceramics with nickel, which exhibited crystalline species characteristic of sodium calcium silicate $\left(\mathrm{Na}_{2} \mathrm{Ca}_{2} \mathrm{Si}_{3} \mathrm{O}_{9}\right.$ and $\left.\mathrm{Na}_{2} \mathrm{CaSi}_{3} \mathrm{O}_{8}\right)$. Furthermore, it was reported that the presence of $\mathrm{Ni}$ did not influence the bioactive behavior of all tested systems that showed apatite formation after 1 day of immersion in SBF $[313,315]$. The cytotoxicity of Ni-doped 45S5 BGs to rabbit derived-osteoblast cells was directly tested. An MTT study revealed that Ni-45S5 BGCs (0-1.65 mol\%) did not show cytotoxic behavior, resulting in higher cell proliferation at $0.82 \mathrm{NiO} \mathrm{mol} \%$ [313].

\subsubsection{Palladium $(\mathrm{Pd})$}

In the biomedical field, palladium has been used in biosensors [316] and anti-cancer treatments [317, 318]. Wu et al. [319] investigated the addition of palladium in sol-gel-derived MBG for catalytic applications to oxidize benzyl alcohol and obtain benzaldehyde, a component that is widely used in the food industry and pharmaceutics. The authors reported that by increasing the amount of $\mathrm{PdCl}_{2}$ above $1.2 \%$, the catalytic activity was reduced, while concentrations between 0.46 and $0.96 \%$ led to an efficient catalytic activity.

\subsubsection{Tungsten (W)}

Tungsten has been considered as non-carcinogenic and nonteratogenic, and it does not hold metabolic properties in animals and humans. In addition, under illumination, it exhibits high photocatalytic activity and antimicrobial properties [320]. Tungsten has gained interest to be incorporated in bioactive glasses due to the potential radiocontrast properties that can be transferred to the material, for example, to visualize the bone restoration process or as radiation shielding material $[321,322]$. In this sense, Medkov et al. [320] developed sol-gel-derived BGs based on the $45 \mathrm{~S} 5$ composition with $\mathrm{WO}_{3}$ ranging from 0 to $4 \mathrm{wt}$. $\%$. At increasing amounts of $\mathrm{WO}_{3}$, microcrystals enriched with tungsten and sodium tungstate were detected and increased radiocontrast values from 1.2 to $5.6 \mathrm{~mm} \mathrm{Al}$, respectively, which are in the adequate range values for monitoring processes. Furthermore, Deliormanli et al. [321] investigated the properties of a composite made of the borate 13-93B3 bioactive glass $\left(5.5 \mathrm{Na}_{2} \mathrm{O}, 11.1 \mathrm{~K}_{2} \mathrm{O}, 4.6\right.$ $\mathrm{MgO}, 18.5 \mathrm{CaO}, 3.7 \mathrm{P}_{2} \mathrm{O}_{5}, 56.6 \mathrm{~B}_{2} \mathrm{O}_{3}$ wt.\%) and tungsten disulfide (0-4 $\mathrm{WS}_{2}$ wt.\%) for diagnostic imaging and radiotherapy applications. In terms of structure, the addition of $\mathrm{WS}_{2}$ in the composites resulted in denser materials with the formation of tungsten trioxide phases and enhanced photon attenuation ability.

\subsection{Halogens}

\subsubsection{Chlorine (Cl)}

One of the essential electrolytes in the human body is chloride. It assists in properly regulating body fluids and the maintenance of fluid balance inside, outside or between cells [323]. $\mathrm{Cl}$ has been incorporated in bioactive glasses for application as additives in toothpaste to help prevent tooth hypersensitivity and promote apatite formation [324-326]. Moreover, chloride has been used as an alternative to fluoride, which has been extensively used in dental applications to prevent caries; however, high content of fluoride in BGs can lead to crystalline calcium fluoride instead of fluorapatite, which might cause dental fluorosis in children [325, 327, 328]. Highly degradable BGs in the system $\mathrm{SiO}_{2}-\mathrm{P}_{2} \mathrm{O}_{5}-\mathrm{CaO}-\mathrm{CaCl}_{2}$ (with $\mathrm{CaCl}_{2}$ in the range of $0-16.6 \mathrm{~mol} \%$ ) have been produced by Chen et al. [327] via the melting route. These glasses exhibited the formation of an apatite-like phase within $3 \mathrm{~h}$ of immersion in Tris buffer and an increasing degradation rate dependent on the amount of $\mathrm{CaCl}_{2}$. Similarly, mixing chloride and fluoride in a glass composition in the form of $\mathrm{CaF}_{2}$ and $\mathrm{CaCl}_{2}$ has also been considered by Chen et al. [329] by the processing of meltderived $\mathrm{BGs}$ in the system $\mathrm{SiO}_{2}-\mathrm{P}_{2} \mathrm{O}_{5}-\mathrm{CaO}-\mathrm{CaF}_{2} / \mathrm{CaCl}_{2}$, with $\mathrm{CaF}_{2}$ content ranging from 1.5 to 13.4 and $\mathrm{CaCl}_{2}$ from 2.6 to 21.5 (mol\%). It was reported that in terms of structural properties, there was no great difference between the BGs. However, due to the difference in the size of fluoride and chloride ions, the crystallization tendency was lower for chloride-containing BGs compared to fluoride BGs. In comparison, a series incorporating both ions resulted in glasses with a stronger crystallization tendency. In terms of material properties, the addition of chloride ions could lead to BGs for applications in mineralizing dental toothpaste or resorbable bone substitutes, although there is still a lack of a comprehensive biological evaluation of such systems.

\subsection{2 lodine (I)}

Iodine has been considered an essential element in the human body since it is involved in the production, 
activation, and metabolism of the thyroid hormone [330]. The ability of iodine ions to provide borate-based BGs antibacterial properties and promote neuron regeneration has been investigated $[114,331,332]$. Ottomeyer et al. [331] reported the antibacterial effect against different bacteria of 13-93B3 BG doped with 2 wt.\% iodine and compared the effect of iodine with that of other dopants such as silver and gallium. The authors reported differences in the bacteria sensitivity with all glass formulations, explained by the distinct mechanisms of the dopant ions. Iodine showed a significant antibacterial effect against $V$. natriegens, $S$. sonnei, $S$ epidermis, and a more negligible effect than undoped 13-93B3 BG against E. coli MRSA and M. catarrhalis. The biological impact of iodine-containing BGs has been studied in vitro by Thyparambil et al. [114] and Gupta et al. [332]. The addition of $0.1 \mathrm{wt} . \%$ of $\mathrm{I}$ in the 13-93B3 composition led to an increased proliferation and migration capacity of ASC cells, resulting in a beneficial approach to stimulate endogenous cells and to accelerate healing processes [114]. In contrast, $0.2 \mathrm{wt} . \%$ of $\mathrm{NaI}$ in 13-93B3 BGs had a significant negative effect on neuron survival and regrowth compared to other dopants such as $\mathrm{Cu}$ or $\mathrm{Ga}$.

\subsection{Other elements}

\subsubsection{Germanium (Ge)}

Germanium is a trace element present in plants, animals, and humans [333]. It has been considered for the treatment of cancer, arthritis, and senile osteoporosis due to the therapeutic attributes such as immune enhancement, oxygen enrichment, and heavy metal detoxification [334]. Germanium containing silicate BGs have been investigated for applications as bone filling materials [335, 336]. Mokhtari et al. [336] investigated the structural properties of $45 \mathrm{~S} 5 \mathrm{BGs}$ containing $\mathrm{Zn}, \mathrm{Sr}$, and Ge ions $\left(48 \mathrm{SiO}_{2}-6 \mathrm{CaO}-8 \mathrm{SrO}-36 \mathrm{ZnO}-2 \mathrm{P}_{2} \mathrm{O}_{5}\right.$ with 6 and $12 \mathrm{~mol} \% \mathrm{GeO}_{2}$ ) to be used as injectable polyalkenoate cement glasses for applications in spinal orthopedic procedures. Amorphous Ge-BGs showed enhanced bioactive behavior compared to the reference glass after immersion in SBF for 4 days, demonstrating that the formation of apatite-like structures was dependent on the amount of $\mathrm{GeO}_{2}$. Furthermore, the nuclear radiation shielding behavior of Ge containing glasses has been studied by Saddeek et al. [337] using computational tools. Alkaline phosphate glasses in the system $\mathrm{P}_{2} \mathrm{O}_{5}-\mathrm{Na}_{2} \mathrm{O}-\mathrm{K}_{2} \mathrm{O}-\mathrm{BaO}-\mathrm{Al}_{2} \mathrm{O}_{3}-\mathrm{Sb}_{2} \mathrm{O}_{3}-\mathrm{La}_{2} \mathrm{O}_{3}-\mathrm{Nb}_{2} \mathrm{O}_{5}-\mathrm{Y}_{2} \mathrm{O}_{3}-$ $\mathrm{Yb}_{2} \mathrm{O}_{3}$ (with 0-84 Mol\% $\mathrm{GeO}_{2}$ ) were evaluated in terms of the effect of $\mathrm{GeO}_{2}$ on the glass mass attenuation parameter and the effective atomic number. Such values resulted increasingly dependent on the amount of $\mathrm{GeO}_{2}$ and indicated the possible use of these materials for gamma shielding applications. In addition, there was a mechanical reinforcement effect with the incorporation of Ge, evidenced in the stronger glass network identified for higher concentrations of germanium oxide.

\subsubsection{Bismuth (Bi)}

Bismuth is a heavy metal ion that possesses antibacterial properties and has been widely used in pharmaceutical applications for the treatment of syphilis, gastrointestinal affections, cancer, and wound infections [338-340]. Average $\mathrm{Bi}$ consumption in humans is reported to be between 5 and $20 \mu \mathrm{g}$ per day [341]. Bismuth-reinforced BGs have shown potential applications for radiation shielding and bone regeneration $[63,251,342,343]$. Bismuth ferrite (BF) has been considered as an effective reinforcement agent in bioactive glasses for stimulating bone tissue formation and accelerating ALP activity [344]. Under the application of magnetic fields of $350 \mathrm{mT}$ during $30 \mathrm{~min}$ per day, the in vitro bioactivity and bone mineralization of a BFcontaining bioactive glass (BF-BG) facilitated bone likeapatite deposition in SBF after 21 days [344]. The addition of $2 \mathrm{wt} . \% \mathrm{BF}$ to BG led to two-fold and three-fold greater ALP activity of MC3T3-E1 cells after 7 and 14 days, respectively, compared to the original glass composition (57 $\mathrm{SiO}_{2}-10 \mathrm{Na}_{2} \mathrm{O}-22 \mathrm{CaO}-6 \mathrm{P}_{2} \mathrm{O}_{5}-2 \mathrm{TiO}_{2}-3 \mathrm{Bi}_{2} \mathrm{O}_{3}$ in wt.\%) [344]. Furthermore, Bi-doped phosphosilicate bioactive glasses (Bi-PBGs) have also shown photothermal effects when exposed to an $808 \mathrm{~nm}$ laser diode demonstrating the potential effect of killing bone tumor cells and enhancing hydroxyapatite mineralization in SBF solution [345]. This study reported cell viability higher than $80 \%$ for different cell lines, namely, mouse fibroblasts (L929), MC3T3-E1, rat osteosarcoma-derived cells (UMR106), and human osteosarcoma cells (U2OS) [345]. Prasad et al. [346] investigated in vitro cell proliferation of mouse fibroblast (NIH3T3) and antibacterial properties of $\mathrm{Bi}$ containing S53P4 BG against $E$. coli. After 11 days, the percentage of cell proliferation exposed to Bi containing S53P4 BG (1 and 2 wt.\%) became higher compared to the non-doped S53P4 glass. In terms of antibacterial properties, $1,2,4$, and $8 \mathrm{wt}$. $\% \quad \mathrm{Bi}_{2} \mathrm{O}_{3}$-containing $\mathrm{S} 53 \mathrm{P} 4$ glass demonstrated antimicrobial effect against $E$. coli with glass powder concentrations of $100 \mathrm{mg} / \mathrm{ml}$ incubated at $37^{\circ} \mathrm{C}$ for 1 and $2 \mathrm{~h}$. In addition, bismuth oxide-doped 45S5 BG nanoparticles showed potential properties for applications as dental root canal sealers [347] and radio-opaque Bi-doped 45S5 BGs produced by pyrolysis of organic solutions have been proposed to control the process of bone regeneration [168].

\subsubsection{Tin (Sn)}

Tin is a trace micronutrient for living organisms reported to be in lower amounts beneficial for cancer treatment [348, 349]. A couple of studies have considered the 
incorporation of Sn into the structure of glasses for biomedical applications [350]. Recently, Alfadhli et al. [350] reported the gamma ray interaction parameters of glasses in the system $\mathrm{PbCl}_{2}-\mathrm{SnCl}_{2}-\mathrm{P}_{2} \mathrm{O}_{5}$ (with $\mathrm{SnCl}_{2}$ content from 40 to $60 \mathrm{~mol} \%$ ) for applications in nuclear medicine. The BG of composition $35 \mathrm{PbCl}_{2}-45 \mathrm{SnCl}_{2}-20 \mathrm{P}_{2} \mathrm{O}_{5}$ exhibited the lowest free path, tenth-value layer, and half-value layer showing superior efficiency to absorb gamma rays.

\subsubsection{Nitrogen $(\mathrm{N})$}

Nitrogen has been reported to enhance the mechanical behavior, antibacterial effect, and the photon attenuation of BGs [351-354]. Bachar et al. [355, 356] studied the influence of nitrogen on the density, hardness, and elastic modulus of melt-derived $\mathrm{BGs}\left(55 \mathrm{SiO}_{2}-13.5 \mathrm{CaO}-31.5\right.$ $\mathrm{Na}_{2} \mathrm{O}, \mathrm{mol} . \%$ ) at various concentration of $\mathrm{Si}_{3} \mathrm{~N}_{4}$ from 0 to $4 \mathrm{~mol} \%$ [355] and $55 \mathrm{SiO}_{2}-8.5 \mathrm{CaO}-31.5 \mathrm{Na}_{2} \mathrm{O}-5 \mathrm{CaF}_{2}$ mol\% (with $\mathrm{Si}_{3} \mathrm{~N}_{4}$ in concentrations of $0-4 \mathrm{~mol} \%$ ) [356]. The incorporated $\mathrm{N}$ atoms into the original tetrahedral $\mathrm{SiO}_{4}$ structure led to a stronger glass network. Consequently, properties such as density, hardness, glass transition temperature, and elastic modulus of $\mathrm{N}$-doped BG significantly increased at higher $\mathrm{N}$ concentrations, while the bioactive behavior decreased [355, 357]. Similarly, bioactive oxynitride glasses (55 $\mathrm{SiO}_{2}-13.5 \mathrm{CaO}-29 \mathrm{Na}_{2} \mathrm{O}-2.5 \mathrm{P}_{2} \mathrm{O}_{5} \mathrm{~mol} \%$ ) with increasing concentration of $\mathrm{Si}_{3} \mathrm{~N}_{4}$ (up to $4 \mathrm{~mol} \%$ ) were studied [357]. In addition to the previously mentioned mechanical properties and bioactivity, these BGs exhibited nontoxic behavior to epithelial cells (L132 cells) at glass powder concentrations of $25-400 \mathrm{mg} / \mathrm{l}$. [357]. Moreover, Marin et al. [358] investigated in vitro the biological behavior of 45S5 BGs doped with $\mathrm{Si}_{3} \mathrm{~N}_{4}$ (5 and $10 \mathrm{~mol} \%$ ). The results revealed that the incorporation of $\mathrm{Si}_{3} \mathrm{~N}_{4}$ into 45S5 BG had a stimulatory effect on the proliferation of $\mathrm{SaOS}-2$ cells and enhanced osteogenic expression for collagen, osteocalcin, and osteopontin [358].

\subsubsection{Tellurium (Te)}

Tellurium is a trace element found in the human body, mainly in bones $(90 \%)$, muscles $(3 \%)$, fat $(3 \%)$, and liver (1.2\%) [359]. Besides, Te has been used to enhance biocompatibility [360], bioactivity [361], and radiation shielding properties [362, 363] of materials for medical applications [364, 365]. Damrawi et al. [361] investigated the bioactivity of tellurite and silicate glass for bioactive implants and dental materials. In vitro bioactivity tests on tellurite glass $\left(50 \mathrm{TeO}_{2}-26 \mathrm{Na}_{2} \mathrm{O}-21 \mathrm{CaO}-3 \mathrm{P}_{2} \mathrm{O}_{5} \mathrm{~mol} \%\right)$ and silicate glass $\left(50 \mathrm{SiO}_{2}-26 \mathrm{Na}_{2} \mathrm{O}-21 \mathrm{CaO}-3 \mathrm{P}_{2} \mathrm{O}_{5} \mathrm{~mol}\right.$ $\%$ ) demonstrated that $\mathrm{TeO}_{2}$ led to accelerated hydroxyapatite nucleation and crystallization compared to the silicate BG after being soaked in SBF for 5 days [361].
In another research, Miola et al. [366] investigated the effects of tellurium $(0-5 \mathrm{~mol} \%)$ on bioactivity and biological behavior of $\mathrm{BGs}$ in the melt-derived system $\mathrm{SiO}_{2}-\mathrm{Na}_{2} \mathrm{O}-\mathrm{CaO}-\mathrm{P}_{2} \mathrm{O}_{5}$ for infection and inflammatory response regulation and to improve bone tissue regeneration. In terms of structural information, Raman spectra of the BGs indicated that Te-incorporated BGs consist of $\mathrm{TeO}_{4}$ and $\mathrm{TeO}_{3}$ structural units. Furthermore, XRD analysis demonstrated that $\mathrm{Te}$ had no influence on the amorphous nature of the glasses. The addition of $1 \mathrm{~mol} \% \mathrm{TeO}_{2}$ resulted in the precipitation of HCA in SBF after 3 days, whereas 5 mol\% Te-containing BG delayed the bioactive behavior in SBF considerably. Compared to Te-free BG, Te-containing glasses demonstrated significant antibacterial and antioxidant effects. Furthermore, the viability of hBMSCs was not negatively affected by the presence of Te in the BGs. Besides, due to tellurium's capacity to prevent the generation of harmful oxygen and nitrogen active species, the metabolic activity of cells in contact with Te-BG under $\mathrm{H}_{2} \mathrm{O}_{2}$ stress was also evaluated, demonstrating the protecting effect of Te ions to cells. Antibacterial tests revealed that Te-containing glasses had a strong antibacterial effect, inhibiting biofilm formation of $S$. aureus and S. epidermidis. After 48 and $72 \mathrm{~h}$ inoculation, 5 mol\% Te-doped BG had a significant effect on biofilm reduction compared to $1 \mathrm{~mol} \%$ Te-containing BG [366].

\subsubsection{Selenium (Se)}

Selenium is an important element for humans in the form of selenocysteine, which is used in enzyme catalysis [367]. Se is particularly vital for the brain, since its lack could lead to irreversible brain damage [367]. In addition, it has been shown that Se intake might be used as a chemopreventive treatment in patients at high risk of pancreatic cancer [368]. Se-doped BGs have shown significant properties for radiation shielding and bone regeneration applications [369373]. MBGs ( $80 \mathrm{SiO}_{2}-15 \mathrm{CaO}-5 \mathrm{P}_{2} \mathrm{O}_{5}$ in mol\%) incorporating $5 \mathrm{~mol} \%$ of selenium (Se-MBGs) have been shown to induce in vitro apatite-forming ability (after 1 days immersion in SBF) [374]. Moreover, Se-MBG was successfully used as a drug delivery system for bone tissue therapy. Thanks to the higher surface area $\left(242 \mathrm{~m}^{2} / \mathrm{g}\right)$ compared to MBG without Se dopants $\left(235 \mathrm{~m}^{2} / \mathrm{g}\right)$, certain oxygen voids and lattice defects caused by the replacement of $\mathrm{Si}^{4+}$ with $\mathrm{Se}^{6+}$ allowed Se-MBG to provide a high DOXloading efficiency (50\%) [374]. The hardness and in vitro biological behavior of selenium oxide-doped 45S5 BG (0.75-6 wt.\% Se) have been investigated by KarakuzuIkizler et al. [375]. Se incorporation improved the Vickers hardness of the BG. Moreover, cell viability of up to $80 \%$ was observed in $45 \mathrm{~S} 5 \mathrm{BG}$ modified with $0.75,1.5,3$, and 6 wt.\% of $\mathrm{SeO}_{2}$ after $24 \mathrm{~h}$ and 7 days of incubation with 
SAOS-2 osteoblast-like cells using extracts concentration of $5 \mathrm{mg} / \mathrm{ml}$ [375]. Besides, compared to 45S5 BG, Se-doped 45S5 BG accelerated the mineralization process in vitro but presented lower APL activity [375]. Hu et al. [376] evaluated the cytotoxic effect of selenium doping in mesoporous bioactive glass nanospheres $\left(60 \mathrm{SiO}_{2}-(36-x) \mathrm{CaO}-4\right.$ $\mathrm{P}_{2} \mathrm{O}_{5}-x \mathrm{SeO}_{2}$ with $x=0,1,3$, and 5 in mol\%). MG 63 osteosarcoma and MC3T3-E1 preosteoblast cells were incubated for $48 \mathrm{~h}$ with Se-MBG supernatants. All the SeMBG-containing nanospheres were significantly toxic for MG 63 cells. However, the $\mathrm{Se}^{4+}$ ion concentrations $(0,1$, and 3 in mol\%) in MBG nanospheres were nontoxic to MC3T3-E1 cells, while 5 mol\% Se (5Se-MBG)-containing nanospheres were significantly toxic for MC3T3-E1 cells at concentrations higher than $20 \mu \mathrm{g} / \mathrm{ml}$ [376]. 3Se-MBG and 5Se-MBG nanospheres showed a significant apoptosis effect on MG 63 cells compared to the control. The Se-free MBG and other Se-MBG nanospheres showed no obvious ability to induce apoptosis [376]. Alternatively, DOX was successfully loaded into Se-MBG nanospheres to improve the viability of MG 63 cells resulting in slightly higher viability than the positive control (free DOX). Moreover, selenium has shown antibacterial effects. This antibacterial activity has been demonstrated incorporating Se-doped borosilicate glass nanoparticles $\left(80 \mathrm{SiO}_{2}-18 \mathrm{~B}_{2} \mathrm{O}_{3}-2 \mathrm{SeO}_{2}\right.$ $\mathrm{mol} \%$ ) in alginate-agarose polymeric blends designed for wound healing applications. The presence of Se-doped borosilicate glass in the polymer showed a significant antibacterial effect against $S$. aureus and Candida albicans compared to only alginate-agarose blend [377].

\section{Discussion}

Bioactive glasses are attracting considerable attention for regenerative medicine and tissue engineering applications due to their excellent features in terms of bioactivity, biodegradability [378], osteogenesis [51], angiogenesis [11], antibacterial [95], anti-inflammatory [379], and immunomodulatory effects [380, 381]. The field of ion releasing BGs for biomedical applications has been growing in the last 20 years, and several comprehensive reviews on different aspects of ion releasing BGs for biomedical use are available [39-41, 49, 53, 54]. More recently, BG compositions incorporating exotic ("exotic" in the sense that such ions are not obviously linked to a biomedical use due to a possible biological activity) or less-common ions have started to be investigated. Numerous studies have shown the use of those ions in silicate-based systems; however, progress has also been made in borate and phosphate glasses. The potential application of BGs relies on their synthesis method, structure, and composition. The incorporation of various therapeutic elements into bioactive glasses has the aim to enhance not only the physical and mechanical properties of the material but, specially, to impart additional features such as bioactivity, biodegradability, osteogenesis, angiogenesis, and antibacterial properties [41]. As can be seen in Table 1, BGs doped with "less-common" ions, namely, rare earth elements and other less obvious ions for biomedical use, have been produced by both the conventional melting-quench and sol-gel methods and have been shaped or processed to achieve several morphologies. Mesoporous BGs produced by sol-gel have shown outstanding characteristics to be used in drug delivery applications [53]. Furthermore, BGs are used for the production of 3Dporous scaffolds fulfilling certain properties such as adequate porosity, mechanical stability, pore interconnectivity, and biocompatibility to facilitate nutrient supply and they can act as suitable signaling templates for bone and soft tissue regeneration [51]. These materials have also been applied as particles or granules to be directly implanted inside a defect [382]. Moreover, BG fibers can exhibit well-ordered structures (e.g., parallel fibers), leading to higher mechanical properties and high bioactivity in SBF [383] as well as suitable properties for drug delivery [59].

The ability of BGs to promote the formation of hydroxyapatite on their surfaces is important as this determines their tissue bonding capability, particularly to hard tissue. The in vitro apatite formation can partially predict the bone formation capacity of doped bioactive glasses. The tunability and control of ion release overtime during the dissolution of BGs have been increasingly investigated to develop bioactive glasses capable of supporting (hard and soft) tissue regeneration by tailored release of biologically active ions. The formation of new bone promoted by BGs can be linked to their chemical durability and dissolution rate in biological fluids. For example, BGs containing lesscommon metal ions have gained special attention due to the positive effect of such ions on the material (BG) bioactive character. For example, the substitution of $\mathrm{Eu}, \mathrm{Sm}, \mathrm{Y}, \mathrm{La}$, $\mathrm{Rb}, \mathrm{Bi}, \mathrm{Se}, \mathrm{Zr}$, and $\mathrm{Ta}$ has been shown to lower chemical durability, which favors apatite formation when the BGs are immersed in SBF solution. On the other hand, glass dissolution decreased in the case of $\mathrm{Gd}$-doped bioactive silicate glass in the system $\mathrm{SiO}_{2}-\mathrm{Na}_{2} \mathrm{O}-\mathrm{CaO}-\mathrm{P}_{2} \mathrm{O}_{5}$ with 2.5 wt.\% $\mathrm{Gd}_{2} \mathrm{O}_{3}$. Still, Gd-doped BGs exhibited high bioactivity after soaking in SBF, indicating that the slow glass dissolution of that particular BG composition had no negative effect on bioactivity in terms of hydroxyapatite formation [85].

In vitro degradation studies in SBF or Tris- $\mathrm{HCl}$ buffer solutions have shown that the incorporation of $\mathrm{Ba}^{2+}, \mathrm{Cr}^{3+}$ (in silicate $\mathrm{BGs}$ ), and $\mathrm{V}^{5+}$ (in borate $\mathrm{BGs}$ ) enhanced the degradation rate of $\mathrm{BGs}$, resulting in superior bioactive behavior. Moreover, increasing concentrations of oxides of $\mathrm{Ba}$ (0-10 mol\% [154]), Cr (0-1 mol\% [241]), and V (0.15-3 wt.\% [266]) boosted the crystallization of hydroxyapatite on BG surfaces. Furthermore, there is no agreement in the literature on the effect of Mo oxide on the 
bioactivity of BGs. Ponta et al. [255] reported that the incorporation of Mo oxide $(5 \mathrm{~mol} \%)$ resulted in a silicatebased BG exhibiting bioactive behavior after 10 days of immersion in SBF; however, Lucacel et al. [257] and ElMeliegy et al. [258] reported that BGs containing $\mathrm{Mo}^{6+}$ $(1-10 \mathrm{~mol} \%$ [257, 258]) did not induce hydroxyapatite formation after 15 days in SBF. This result was explained by the presence of dominant $\mathrm{Mo}^{5+}$ ionic species on the surface inhibiting the migration of $\mathrm{Ca}^{2+}$ and $\mathrm{PO}_{4}{ }^{3-}$ groups to the glass surface [257]. Moreover, the addition of $\mathrm{Ba}$ to borosilicate glasses might improve the radiation shielding ability of the materials, described by the fact that increasing amount of $\mathrm{BaO}$ in the glass system produces an increase of the glass density resulting in enhanced resistance to gamma radiation [160].

Materials intended to be implanted in the body or in contact with open wounds must exhibit a number of properties linked to their biocompatible characteristics. Toxic effects can cause harm to the host tissue and should be prevented. The addition of less-common ions, which are not obviously considered for their cell biology activity, must include an assessment of biotolerance as function of concentration. As a result, the possible toxic effects of incorporating different ions in BGs require careful investigation both in vitro and in vivo. In this context, the influence of doping BGs with $\mathrm{Eu}, \mathrm{Gd}, \mathrm{La}$, $\mathrm{Bi}, \mathrm{Se}, \mathrm{Zr}$, and $\mathrm{Nb}$ on living cells, such as mouse fibroblasts L929 [384], macrophages (RAW 264.7) [69], osteoblasts (MC3T3-E1) [60], BHK fibroblasts [118], rat osteosarcomaderived (UMR106) [345], and human osteosarcoma (U2OS) cells [201], has been investigated and always an ion dosedependent response has been found. Results have shown that dissolution products of BGs containing the mentioned ions are nontoxic at low concentrations. Similarly, bioactive glasses with doping ions such as $\mathrm{Ba}^{2+}, \mathrm{Mo}^{6+}$, and $\mathrm{Te}^{4+}$ did not show any cytotoxicity effect on different cell lines, for example, on glioblastoma cells and granulocytic 466 cells (at $1.35 \mathrm{~mol} \%$ Ba-doped BG) [9], L929 mouse fibroblast (0-10 mol\% Ba [154]), human bone marrow-derived stem cells $(0-5 \mathrm{~mol} \% \mathrm{Te}[366])$, as well as RCs and human bone marrow-derived stem cells ( $7.5 \mathrm{~mol} \%$ Mo [256]). Even though progress has been made on investigating cytotoxicity, to the authors' knowledge, no specific studies on the cytotoxicity of Sm-, Y-, Cr-, V-, and Rb-containing bioactive glasses have been reported so far and this is an important aspect that should be investigated in more detail to take advantage of the therapeutic properties that these ions could provide for tissue regeneration.

A challenge for tissue engineering is to devise an effective approach to use biomaterials that are not only suitable in terms of mechanical stability (according to the host tissue) but also promote the relevant healing and regenerative processes including angiogenesis as a key requirement for both soft and bone tissue engineering.
Adding "less-common" ions to BGs is an approach that is becoming highly considered in parallel to the use of the more "standard" ions such as $\mathrm{Sr}, \mathrm{Cu}, \mathrm{Zn}, \mathrm{Ag}, \mathrm{Mg}$, and $\mathrm{Co}$. For example, the use of $\mathrm{Eu}, \mathrm{La}$, and $\mathrm{Rb}$ in silicate-based bioactive glasses led to improved osteogenic and angiogenic responses in mouse bone marrow stromal cells, hBMSCs, and endothelial-like cells (HUVECs). Furthermore, finding the right concentration of doping ions is important to gain information on their toxic levels and also to determine the minimum amount necessary to provide a therapeutic effect. Therefore, in vitro studies have been carried out using different ionic concentrations. For example, $\mathrm{Eu}^{3+}$ (in the range of $6.25-25 \mathrm{mg} / \mathrm{ml}$ ) [70], $\mathrm{La}^{3+}$ $(50 \mathrm{mg} / \mathrm{ml})$ [117], and $\mathrm{Rb}^{+}(100 \mathrm{mg} / \mathrm{ml})$ [141] incorporated in different BGs have been shown to activate the Wnt/ $\beta$-catenin, and HIF- $1 \alpha$ signaling pathways to upregulate the secretion of osteogenic genes (RUNX2, ALP, OPN, OSX, and BSP and COL I) as well as the promotion of angiogenic growth factors (b-FGF, VEGF, PDGF and, CD31, PDGFR $\alpha / \beta$, VEGFR $1 / 2$, and MMP9). High concentrations of doping ions, on the other hand, resulted in being harmful to cells [70]. Other elements, such as Gd [89, 90], Zr [198], and $\mathrm{Nb}$ [230], have been shown to enhance osteoblast activity when tested in vitro with rBMSCs, MC3T3-E1, and BMSCs cells, respectively.

Photoluminescence features of rare earth ions have been investigated in MBG fibers doped with europium and samarium. These rare earth ion-doped BGs have the potential to be used in bioimaging, for instance, for the in vivo monitoring of new bone growth in bone defects [70] and in applications where monitoring the material degradation is desired [96] or as drug delivery carriers [56, 58]. Furthermore, the inhibitory activity of Eu-doped MBGs on the expression of pro-inflammatory factors such as IL-18, IL-6, IL-1, OSM MyD88, Ticam1, TNF- $\alpha$, and Ticom2 has also been investigated [69, 379]. Clearly, such ions offer an interesting combination of functional properties and biological effects, which cannot be obtained by the classical doping ions.

Infection is a major cause of implant failure, being bacterial adhesion and biofilm formation the main causes of infection [385]. Bioactive glasses doped with metal cations such as rubidium [141], selenium [377], and zirconium [183] have been shown to impart high antibacterial activity against S. aureus, E. coli, and P. aeruginosa. Likewise, tellurium has been described as a doping ion that promotes antibacterial effects and antioxidant effects on BGs. Antibacterial properties against $S$. aureus and $S$. epidermidis have been reported for BGs with high $\mathrm{TeO}_{2}$ concentrations (5 mol\%) [361].

Furthermore, Rb-doped mesoporous glass scaffolds have been developed as promising templates for drug loading [141]. Indeed, the long-term consequences of bacterial resistance to antibiotics give future perspectives for the development of new antibiotic-free materials for 
Table 3 Effects "less-common" ions incorporated in bioactive glasses

\begin{tabular}{|c|c|c|}
\hline Ion & Effects & Ref. \\
\hline \multirow[t]{5}{*}{ Barium } & Apatite-forming bioactivity & [9] \\
\hline & Biocompatible behavior & [9] \\
\hline & Anti-inflammatory properties & [9] \\
\hline & Gamma radiation properties & {$[160]$} \\
\hline & Increases density transmission and optical bandgap & {$[160]$} \\
\hline \multirow[t]{4}{*}{ Bismuth } & Apatite-forming bioactivity & [344] \\
\hline & Increases the expression of ALP & [344] \\
\hline & Biocompatible behavior & [345] \\
\hline & Antibacterial property against gram-negative bacteria & [346] \\
\hline \multirow[t]{2}{*}{ Chlorine } & Increases apatite-forming bioactivity & {$[324-327]$} \\
\hline & Decreases glass durability & {$[327]$} \\
\hline \multirow[t]{2}{*}{ Chromium } & Decreases glass durability & {$[241]$} \\
\hline & Bioactive behavior & {$[241]$} \\
\hline Dysprosium & Controlling drug release & [133] \\
\hline \multirow[t]{7}{*}{ Europium } & Photoluminescence properties & {$[58,59,69,70]$} \\
\hline & Controlling drug release & {$[57-59]$} \\
\hline & Promoting osteogenesis and angiogenesis potential & [69] \\
\hline & Increases cell viability & {$[57]$} \\
\hline & Increases apatite-forming bioactivity & {$[60]$} \\
\hline & $\begin{array}{l}\text { Increases the expression of ALP, COL1, and Runx } 2 \\
\text { genes and promoted osteogenic differentiation } \\
\text { of BMSCs }\end{array}$ & {$[70]$} \\
\hline & Decreases glass durability & {$[70]$} \\
\hline \multirow{6}{*}{$\begin{array}{l}\text { Gadolinium or } \\
\text { Ytterbium or Thulium }\end{array}$} & Increases glass durability & {$[85]$} \\
\hline & Biocompatible behavior & {$[85]$} \\
\hline & $\begin{array}{l}\text { Promoting proliferation and differentiation of rBMSCs } \\
\text { cells and human exfoliated deciduous teeth (SHED) }\end{array}$ & {$[85,89,90]$} \\
\hline & $\begin{array}{l}\text { Promoting newly formed bone and collagen deposition } \\
\text { in rats, calvarial defect model, after } 12 \text { weeks post } \\
\text { surgery }\end{array}$ & {$[90]$} \\
\hline & Decreases the average particle size & [91] \\
\hline & Photoluminescence properties & [91] \\
\hline \multirow[t]{3}{*}{ Germanium } & Increases apatite-forming bioactivity & [336] \\
\hline & Nuclear radiation shielding behaviors & [337] \\
\hline & Increase bulk modulus and Young's modulus & [337] \\
\hline \multirow[t]{2}{*}{ Gold } & $\begin{array}{l}\text { Antibacterial property against gram-positive and gram- } \\
\text { negative bacteria }\end{array}$ & [306] \\
\hline & Apatite-forming bioactivity & [305] \\
\hline \multirow[t]{3}{*}{ Holmium } & Promoting preosteoblast cell proliferation & [78] \\
\hline & Biocompatible behavior & [78] \\
\hline & Bioactive behavior & {$[78,79]$} \\
\hline \multirow[t]{3}{*}{ Iodine } & $\begin{array}{l}\text { Increases proliferation and migration capacity of } \\
\text { ASC cells }\end{array}$ & [114] \\
\hline & $\begin{array}{l}\text { Antibacterial properties against } V . \text { natriegens, } S . \text { sonnei, } \\
S \text { epidermis, E. coli MRSA, and } M \text {. catarrhalis }\end{array}$ & {$[331]$} \\
\hline & Negative effect on neuron survival and regrowth & [332] \\
\hline \multirow[t]{2}{*}{ Lanthanum } & Decreases polymerizing silica network & {$[124]$} \\
\hline & Increases compressive strength & [124] \\
\hline Manganese & Increases apatite-forming bioactivity & [282] \\
\hline
\end{tabular}


Table 3 (continued)

\begin{tabular}{|c|c|c|}
\hline Ion & Effects & Ref. \\
\hline & Promoting osteogenic properties in vitro & {$[282]$} \\
\hline & Biocompatible behavior & [284] \\
\hline & $\begin{array}{l}\text { Antibacterial properties against gram-positive and gram- } \\
\text { negative bacteria }\end{array}$ & [285] \\
\hline \multirow[t]{4}{*}{ Molybdenum } & Increases mechanical strength & {$[255]$} \\
\hline & Biocompatible behavior & [255] \\
\hline & Decreases glass durability & {$[256]$} \\
\hline & Controlling drug release & {$[257]$} \\
\hline \multirow[t]{2}{*}{ Nickel } & $\begin{array}{l}\text { Increase density, microhardness compressive strength, } \\
\text { and flexural strength }\end{array}$ & {$[313-315]$} \\
\hline & Biocompatible behavior & {$[314]$} \\
\hline \multirow[t]{5}{*}{ Niobium } & Increases apatite-forming bioactivity & [230] \\
\hline & Biocompatible behavior & {$[229,230,233]$} \\
\hline & Increases chemical durability & [229] \\
\hline & $\begin{array}{l}\text { Increases Vickers microhardness and compressive } \\
\text { strength }\end{array}$ & [229] \\
\hline & Promoting osteogenic and osteostimulative properties & {$[230,232,233]$} \\
\hline \multirow[t]{3}{*}{ Nitrogen } & $\begin{array}{l}\text { Increase density, hardness, glass transition temperature, } \\
\text { and elastic modulus }\end{array}$ & {$[355-357,394]$} \\
\hline & Biocompatible behavior & {$[357]$} \\
\hline & $\begin{array}{l}\text { Increase osteogenic expression for collagen, osteocalcin, } \\
\text { and osteopontin }\end{array}$ & {$[358]$} \\
\hline Palladium & High catalytic activity on benzyl alcohol oxidation & [319] \\
\hline \multirow[t]{6}{*}{ Rubidium } & Biocompatible behavior & {$[118,123]$} \\
\hline & Increases apatite-forming bioactivity & [346] \\
\hline & Promoting angiogenesis and osteogenesis of hBMSCs & [118] \\
\hline & $\begin{array}{l}\text { Antibacterial property against gram-positive and gram- } \\
\text { negative bacteria }\end{array}$ & {$[140,346]$} \\
\hline & Increases density and tensile strength & {$[141,142]$} \\
\hline & Antibacterial properties against gram-negative bacteria & {$[346,395]$} \\
\hline \multirow[t]{4}{*}{ Samarium } & $\begin{array}{l}\text { Increases density, Young's modulus, bulk modulus, and } \\
\text { shear modulus }\end{array}$ & [97] \\
\hline & Increases apatite-forming bioactivity & {$[97,98]$} \\
\hline & Photoluminescence properties & [93] \\
\hline & Controlling drug release & [98] \\
\hline \multirow[t]{4}{*}{ Selenium } & Increases apatite-forming bioactivity & {$[375,376,390]$} \\
\hline & Controlling drug release & {$[376]$} \\
\hline & Increases Vickers microhardness & [375] \\
\hline & Biocompatible behavior & [375] \\
\hline \multirow[t]{4}{*}{ Tantalum } & Increases apatite-forming bioactivity & [173] \\
\hline & $\begin{array}{l}\text { Antibacterial properties against gram-positive and gram- } \\
\text { negative bacteria }\end{array}$ & [173] \\
\hline & Biocompatible behavior & {$[162]$} \\
\hline & Promoting hemostasis & {$[162]$} \\
\hline \multirow[t]{3}{*}{ Tellurium } & Apatite-forming bioactivity & {$[366]$} \\
\hline & $\begin{array}{l}\text { Antibacterial properties against gram-positive and gram- } \\
\text { negative bacteria }\end{array}$ & {$[366]$} \\
\hline & Antioxidant properties & [366] \\
\hline Terbium and Erbium & Biocompatible behavior & {$[59,130]$} \\
\hline
\end{tabular}


Table 3 (continued)

\begin{tabular}{|c|c|c|}
\hline Ion & Effects & Ref. \\
\hline & $\begin{array}{l}\text { Photoluminescence properties } \\
\text { Increases apatite-forming bioactivity }\end{array}$ & $\begin{array}{l}{[59,396]} \\
{[59,130,396]}\end{array}$ \\
\hline Tin & High gamma rays efficiency & {$[350]$} \\
\hline \multirow[t]{3}{*}{ Tungsten } & Increases radiocontrast values & {$[320]$} \\
\hline & $\begin{array}{l}\text { Increases density, Vickers microhardness, and } \\
\text { compressive strength }\end{array}$ & {$[321]$} \\
\hline & Enhancing photon attenuation ability & {$[321]$} \\
\hline \multirow[t]{4}{*}{ Vanadium } & Decreases glass durability & [266] \\
\hline & Apatite-forming bioactivity & [266] \\
\hline & Photoluminescence properties & [269] \\
\hline & Gamma radiation properties & {$[270]$} \\
\hline \multirow[t]{3}{*}{ Yttrium } & Increases glass durability & {$[112,113]$} \\
\hline & Increase apatite-forming bioactivity & {$[105]$} \\
\hline & $\begin{array}{l}\text { Promoting proliferation and migration of adipose stem } \\
\text { cells (ASCs) }\end{array}$ & {$[114]$} \\
\hline \multirow[t]{7}{*}{ Zirconium } & Increases apatite-forming bioactivity & {$[175,197]$} \\
\hline & Decreases glass durability & [197] \\
\hline & Decreases polymerizing silica networks & [197] \\
\hline & $\begin{array}{l}\text { Increases density, Vickers microhardness, compressive } \\
\text { strength, and fracture toughness }\end{array}$ & {$[175,183,197,198]$} \\
\hline & $\begin{array}{l}\text { Antibacterial properties against gram-positive and gram- } \\
\text { negative bacteria }\end{array}$ & {$[175,198]$} \\
\hline & Biocompatible behavior & {$[175]$} \\
\hline & $\begin{array}{l}\text { Promoting proliferation and activity of osteoblast- } \\
\text { like cells }\end{array}$ & [198] \\
\hline
\end{tabular}

use in medicine. Bioactive glasses have great potential in this field, especially when antibacterial ions are incorporated in the right amount and can be released in a controlled manner representing an alternative antibacterial technology. In this context, the dual release of antibiotics and antibacterial ions from MBGs is a powerful emerging approach, as recently discussed [386], exploiting synergies that can emerge by the simultaneous release of ions and biomolecules.

Since bioactive glasses have shown drawbacks in terms of mechanical properties and fracture resistance, research focusing on alternatives to improve such properties is being increasingly carried out. The mechanical strength of BGs can be tailored by adjusting the chemical composition and by inducing crystallization [387]. As a result, several ions, including selenium and zirconium, have effectively been incorporated into bioactive glasses to enhance their mechanical properties. The development of new crystalline phases such as $\mathrm{ZrSiO}, \mathrm{ZrSiO}_{4}, \mathrm{Zr}_{2} \mathrm{O}$ $\left(\mathrm{PO}_{4}\right)$, and $\mathrm{Ca}\left(\mathrm{ZrO}_{3}\right)$ has been shown to increase the compressive strength of $\mathrm{Zr}$-containing BGs. However, the controlled crystallization of BGs incorporating lesscommon ions as an strategy to obtain better mechanical properties has not been extensively exploited so far.
Based on the results reported in the literature, which have been summarized and discussed in this review, it can be stated that there is still a lack of studies evaluating the longterm performance of BGs incorporating less-common ions, especially with an assessment of their biological behavior in vivo, including long-term studies to assess possible delayed cytotoxic effects of such ions. In addition, more studies need to be carried out considering the applications of ion-doped BGs in the production of 3D constructs and scaffolds since most of the reported studies have considered BGs in particulate form. In comparison to the much higher amount of data on BGs containing "classical" ions such as $\mathrm{Cu}, \mathrm{Sr}, \mathrm{B}, \mathrm{Li}, \mathrm{Mg}, \mathrm{K}, \mathrm{Co}$, studies on BGs incorporating "lesscommon" ions discussed in this review are scarce; however, the field is highly promising and is expanding, with new research continuously generating data to complete our understanding about the properties and applications of such BGs.

\section{Conclusions}

According to this literature review, research is increasingly focusing on improving the properties of bioactive glasses by 
doping them with less common dopants, including rare-earth elements. The addition of these dopants alters the bioactive glass properties imparting novel functionalities and induces specific biological effects. The use of rare earth elements in bioactive glasses also expands their medical applications, considering the achieved therapeutic effects combined with functional properties (e.g., for imaging applications). In this paper, we have reviewed and discussed current knowledge on the effects of less-common ions on the properties of bioactive glasses, as summarized in Table 3. We anticipate further expansion of research on this particular class of BGs and propose this review as a timely addition to the literature for the benefit of those researchers entering the field.

Acknowledgements UP acknowledges the Royal Thai Government scholarship (Ministry of Higher Education, Science, Research and Innovation). Support by the German Research Foundation (Deutsche Forschungsgemeinschaft, DFG), project number BO1191/26-1, is acknowledged.

Funding Open Access funding enabled and organized by Projekt DEAL.

\section{Compliance with ethical standards}

Conflict of interest The authors declare no competing interests.

Publisher's note Springer Nature remains neutral with regard to jurisdictional claims in published maps and institutional affiliations.

Open Access This article is licensed under a Creative Commons Attribution 4.0 International License, which permits use, sharing, adaptation, distribution and reproduction in any medium or format, as long as you give appropriate credit to the original author(s) and the source, provide a link to the Creative Commons license, and indicate if changes were made. The images or other third party material in this article are included in the article's Creative Commons license, unless indicated otherwise in a credit line to the material. If material is not included in the article's Creative Commons license and your intended use is not permitted by statutory regulation or exceeds the permitted use, you will need to obtain permission directly from the copyright holder. To view a copy of this license, visit http://creativecommons. org/licenses/by/4.0/.

\section{References}

1. Boccaccini AR, Brauer DS, Hupa L, editors. Bioactive glasses (Smart Materials Series). Cambridge: Royal Society of Chemistry; 2016. p. P001-530. https://doi.org/10.1039/9781782622017.

2. Jones JR. Review of bioactive glass: from hench to hybrids. Acta Biomater. 2013;9:4457-86. https://linkinghub.elsevier.com/ retrieve/pii/S1742706112003996.

3. Kim J-J, El-Fiqi A, Kim H-W. Synergetic cues of bioactive nanoparticles and nanofibrous structure in bone scaffolds to stimulate osteogenesis and angiogenesis. ACS Appl Mater Interfaces. 2017;9:2059-73. https://doi.org/10.1021/acsami.6b12089.

4. Yan L, Li H, Xia W. Bioglass could increase cell membrane fluidity with ion products to develop its bioactivity. Cell Prolif. 2020;53:1-16. https://doi.org/10.1111/cpr.12906.
5. Saha S, Bhattacharjee A, Rahaman SH, Ray S, Marei MK, Jain $\mathrm{H}$, et al. Prospects of antibacterial bioactive glass nanofibers for wound healing: an in vitro study. Int $\mathbf{J}$ Appl Glas Sci. 2020;11:320-8. https://doi.org/10.1111/ijag.15029.

6. Dai LL, Mei ML, Chu CH, Lo ECM. Antibacterial effect of a new bioactive glass on cariogenic bacteria. Arch Oral Biol. 2020;117:104833. https://doi.org/10.1016/j.archoralbio.2020. 104833.

7. Zheng K, Dai X, Lu M, Hüser N, Taccardi N, Boccaccini AR. Synthesis of copper-containing bioactive glass nanoparticles using a modified Stöber method for biomedical applications. Colloids Surf B Biointerfaces. 2017;150:159-67. https://doi.org/ 10.1016/j.colsurfb.2016.11.016.

8. Kargozar S, Montazerian M, Hamzehlou S, Kim H-W, Baino F. Mesoporous bioactive glasses (MBGs): promising platforms for antibacterial strategies Saeid. Acta Biomater. 2018:81:1-19. https://doi.org/10.1016/j.actbio.2018.09.052.

9. Majumdar S, Hira SK, Tripathi H, Kumar AS, Manna PP, Singh SP, et al. Synthesis and characterization of barium-doped bioactive glass with potential anti-inflammatory activity. Ceram Int. 2021;47:7143-58. https://doi.org/10.1016/j.ceramint.2020. 11.068 .

10. Björkenheim R, Jämsen E, Eriksson E, Uppstu P, Aalto-Setälä L, Hupa L, et al. Sintered S53P4 bioactive glass scaffolds have antiinflammatory properties and stimulate osteogenesis in vitro. Eur Cells Mater. 2021;41:15-30. https://www.ecmjournal.org/pa pers/vol041/pdf/v041a02.pdf.

11. Kargozar S, Baino F, Hamzehlou S, Hill RG, Mozafari M. Bioactive glasses: sprouting angiogenesis in tissue engineering. Trends Biotechnol. 2018;36:430-44. https://linkinghub.elsevier. com/retrieve/pii/S0167779917303244.

12. Miguez-Pacheco V, Hench LL, Boccaccini AR. Bioactive glasses beyond bone and teeth: emerging applications in contact with soft tissues. Acta Biomater. 2015;13:1-15. https://linkinghub. elsevier.com/retrieve/pii/S1742706114004966.

13. Hench LL, Splinter RJ, Allen WC, Greenlee TK. Bonding mechanisms at the interface of ceramic prosthetic materials. J Biomed Mater Res. 1971;5:117-41.

14. Mubina MSK, Shailajha S, Sankaranarayanan R, Saranya L. In vitro bioactivity, mechanical behavior and antibacterial properties of mesoporous $\mathrm{SiO} 2-\mathrm{CaO}-\mathrm{Na} 2 \mathrm{O}-\mathrm{P} 2 \mathrm{O} 5$ nano bioactive glass ceramics. J Mech Behav Biomed Mater. 2019;100:103379. https://doi.org/10.1016/j.jmbbm.2019.103379.

15. Balasubramanian P, Büttner T, Miguez Pacheco V, Boccaccini AR. Boron-containing bioactive glasses in bone and soft tissue engineering. J Eur Ceram Soc. 2018;38:855-69. https:// linkinghub.elsevier.com/retrieve/pii/S0955221917307409.

16. Schuhladen K, Wang X, Hupa L, Boccaccini AR. Dissolution of borate and borosilicate bioactive glasses and the influence of ion $(\mathrm{Zn}, \mathrm{Cu})$ doping in different solutions. J Non Cryst Solids. 2018;502:22-34. https://linkinghub.elsevier.com/retrieve/pii/ S0022309318305003.

17. Elgayar I, Aliev AE, Boccaccini AR, Hill RG. Structural analysis of bioactive glasses. J Non Cryst Solids. 2005;351:173-83. https://linkinghub.elsevier.com/retrieve/pii/ S0022309304004557.

18. Arango-Ospina M, Hupa L, Boccaccini AR. Bioactivity and dissolution behavior of boron-containing bioactive glasses under static and dynamic conditions in different media. Biomed Glas. 2019;5:124-39. https://doi.org/10.1515/bglass-2019-0011/html.

19. Westhauser F, Hohenbild F, Arango-Ospina M, Schmitz SI, Wilkesmann S, Hupa L, et al. Bioactive glass (BG) ICIE16 shows promising osteogenic properties compared to crystallized 45S5-BG. Int J Mol Sci. 2020;21:1639 https://www.mdpi.com/ 1422-0067/21/5/1639https://www.mdpi.com/1422-0067/21/5/ 1639https://www.mdpi.com/1422-0067/21/5/1639. 
20. Brink M, Turunen T, Happonen R-P, Yli-Urpo A. Compositional dependence of bioactivity of glasses in the system Na2O-K2O$\mathrm{MgO}-\mathrm{CaO}-\mathrm{B} 2 \mathrm{O} 3-\mathrm{P} 2 \mathrm{O} 5-\mathrm{SiO} 2 . \mathrm{J}$ Biomed Mater Res. 1997;37:114-21.

21. Brink M. The influence of alkali and alkaline earths on the working range for bioactive glasses. J Biomed Mater Res. 1997;36:109-17.

22. Deilmann L, Winter O, Cerrutti B, Bradtmüller H, Herzig C, Limbeck A, et al. Effect of boron incorporation on the bioactivity, structure, and mechanical properties of ordered mesoporous bioactive glasses. J Mater Chem B. 2020;8:1456-65. http:// xlink.rsc.org/?DOI=C9TB01805K.

23. Prasad SS, Datta S, Adarsh T, Diwan P, Annapurna K, Kundu B, et al. Effect of boron oxide addition on structural, thermal, in vitro bioactivity and antibacterial properties of bioactive glasses in the base S53P4 composition. J Non Cryst Solids. 2018;498:204-15. https://doi.org/10.1016/j.jnoncrysol.2018.06. 027.

24. Houaoui A, Lyyra I, Agniel R, Pauthe E, Massera J, Boissière M. Dissolution, bioactivity and osteogenic properties of composites based on polymer and silicate or borosilicate bioactive glass. Mater Sci Eng C. 2020;107:110340. https://doi.org/10.1016/j. msec.2019.110340.

25. Moonesi Rad R, Atila D, Evis Z, Keskin D, Tezcaner A. Development of a novel functionally graded membrane containing boron-modified bioactive glass nanoparticles for guided bone regeneration. J Tissue Eng Regen Med. 2019;13:1331-45. https://doi.org/10.1002/term.2877.

26. Xia L, Ma W, Zhou Y, Gui Z, Yao A, Wang D, et al. Stimulatory effects of boron containing bioactive glass on osteogenesis and angiogenesis of polycaprolactone: in vitro study. Biomed Res Int. 2019;2019:8961409. https://hindawi.com/journals/bmri/ 2019/8961409/.

27. Chen $S$, Michálek M, Galusková D, Michálková M, Švancárek $\mathrm{P}$, Talimian A, et al. Multi-targeted B and Co co-doped 45S5 bioactive glasses with angiogenic potential for bone regeneration. Mater Sci Eng C. 2020;112:110909. https://doi.org/10. 1016/j.msec.2020.110909.

28. Haro Durand LA, Vargas GE, Romero NM, Vera-Mesones R, Porto-López JM, Boccaccini AR, et al. Angiogenic effects of ionic dissolution products released from a boron-doped 45S5 bioactive glass. J Mater Chem B. 2015;3:1142-8. http://xlink.rsc. org/?DOI=C4TB01840K.

29. Balasubramanian P, Grünewald A, Detsch R, Hupa L, Jokic B, Tallia F, et al. Ion release, hydroxyapatite conversion, and cytotoxicity of boron-containing bioactive glass scaffolds. Int $\mathbf{J}$ Appl Glas Sci 2016;7:206-15. https://onlinelibrary.wiley.com/ doi/10.1111/ijag.12206.

30. Stanic V. Chapter 8 - Boron-containing bioactive glasses for bone regeneration. In: Kaur G, editor. Biomedical, therapeutic and clinical applications of bioactive glasses. Elsevier; 2019. p. 219-49. https://linkinghub.elsevier.com/retrieve/pii/B9780081 021965000082 .

31. Lapa A, Cresswell M, Jackson P, Boccaccini AR. Phosphate glass fibres with therapeutic ions release capability - a review. Adv Appl Ceram. 2020;119:1-14. https://doi.org/10.1080/ 17436753.2018.1564413.

32. Sharmin N, Rudd CD. Structure, thermal properties, dissolution behaviour and biomedical applications of phosphate glasses and fibres: a review. J Mater Sci. 2017;52:8733-60. https://doi.org/ 10.1007/s10853-017-0784-4.

33. Araujo MS, Silva AC, Bartolomé JF, Mello-Castanho S. Structural and thermal behavior of $45 \mathrm{~S} 5$ Bioglass $^{\circledR}$-based compositions containing alumina and strontium. J Am Ceram Soc. 2020;103:3620-30. https://doi.org/10.1111/jace.17061.
34. Yeliz BE, Burcu KI, Serpil KD, Sevil Y, Ismail A. Investigation of alumina doped $45 \mathrm{~S} 5$ glass as a bioactive filler for experimental dental composites. Int J Appl Glas Sci. 2021;12:313-27. https:// doi.org/10.1111/ijag.16043.

35. Dey P, Pal SK, Sarkar R. Effect of alumina addition on $45 \mathrm{~S} 5$ bioglass. Trans Indian Ceram Soc. 2014;73:105-9. https://doi. org/10.1080/0371750X.2014.922423.

36. Melchers S, Uesbeck T, Winter O, Eckert H, Eder D. Effect of aluminum ion incorporation on the bioactivity and structure in mesoporous bioactive glasses. Chem Mater. 2016;28:3254-64. https://doi.org/10.1021/acs.chemmater.5b04117.

37. Thompson KH. Boon and bane of metal ions in medicine. Science. 2003;300:936-9. https://doi.org/10.1126/science.1083004.

38. Spadaro JA, Becker RO, Bachman $\mathrm{CH}$. The distribution of trace metal ions in bone and tendon. Calcif Tissue Res. 1970;6:49-54. https://doi.org/10.1007/BF02196183.

39. Rabiee SM, Nazparvar N, Azizian M, Vashaee D, Tayebi L. Effect of ion substitution on properties of bioactive glasses: a review. Ceram Int. 2015;41:7241-51. https://doi.org/10.1016/j. ceramint.2015.02.140.

40. O'Neill E, Awale G, Daneshmandi L, Umerah O, Lo KWH. The roles of ions on bone regeneration. Drug Disco Today. 2018;23:879-90. https://doi.org/10.1016/j.drudis.2018.01.049.

41. Hoppe A, Güldal NS, Boccaccini AR. A review of the biological response to ionic dissolution products from bioactive glasses and glass-ceramics. Biomaterials. 2011;32:2757-74. https://doi.org/ 10.1016/j.biomaterials.2011.01.004.

42. Hoppe A, Mouriño V, Boccaccini AR. Therapeutic inorganic ions in bioactive glasses to enhance bone formation and beyond. Biomater Sci. 2013;1:254-6. http://xlink.rsc.org/?DOI= C2BM00116K.

43. Kaur G, Pandey OP, Singh K, Homa D, Scott B, Pickrell G. A review of bioactive glasses: their structure, properties, fabrication and apatite formation. $\mathrm{J}$ Biomed Mater Res Part A. 2014;102:254-74. https://onlinelibrary.wiley.com/doi/10.1002/ jbm.a.34690.

44. Bohner M, Santoni BLG, Döbelin N. $\beta$-tricalcium phosphate for bone substitution: synthesis and properties. Acta Biomater. 2020;113:23-41. https://linkinghub.elsevier.com/retrieve/pii/ S1742706120303524.

45. Adzila S, Murad M, Sopyan I. Doping metal into calcium phosphate phase for better performance of bone implant materials. Recent patents. Mater Sci. 2012;5:18-47. https://www. eurekaselect.com/94895/article/doping-metal-calcium-phospha te-phase-better-performance-bone-implant-materials.

46. Laskus A, Kolmas J. Ionic substitutions in non-apatitic calcium phosphates. Int J Mol Sci. 2017;18:2542 http://www.mdpi.com/ 1422-0067/18/12/2542.

47. Naseri S, Lepry WC, Nazhat SN. Bioactive glasses in wound healing: hope or hype? J Mater Chem B. 2017;5:6167-74. http:// xlink.rsc.org/?DOI $=$ C7TB01221G.

48. Westhauser F, Arango-Ospina M, Losch S, Wilkesmann S, Lehner B, Ali MS, et al. Selective and caspase-independent cytotoxicity of bioactive glasses towards giant cell tumor of bone derived neoplastic stromal cells but not to bone marrow derived stromal cells. Biomater. 2021;275:120977 https://linkinghub. elsevier.com/retrieve/pii/S0142961221003331.

49. Schatkoski VM, Larissa do Amaral Montanheiro T, Canuto de Menezes BR, Pereira RM, Rodrigues KF, Ribas RG, et al. Current advances concerning the most cited metal ions doped bioceramics and silicate-based bioactive glasses for bone tissue engineering. Ceram Int. 2021;47:2999-3012. https://linkinghub. elsevier.com/retrieve/pii/S0272884220329175.

50. Mehrabi T, Mesgar AS, Mohammadi Z. Bioactive glasses: a promising therapeutic ion release strategy for enhancing wound 
healing. ACS Biomater Sci Eng. 2020;6:5399-430. https://doi. org/10.1021/acsbiomaterials.0c00528.

51. El-Rashidy AA, Roether JA, Harhaus L, Kneser U, Boccaccini AR. Regenerating bone with bioactive glass scaffolds: a review of in vivo studies in bone defect models. Acta Biomater. 2017;62:1-28. https://doi.org/10.1016/j.actbio.2017.08.030.

52. Balasubramanian P, Strobel LA, Kneser U, Boccaccini AR. Zinc-containing bioactive glasses for bone regeneration, dental and orthopedic applications. Biomed Glas. 2015;1:51-69. https:// doi.org/10.1515/bglass-2015-0006/html.

53. Wu C, Chang J. Multifunctional mesoporous bioactive glasses for effective delivery of therapeutic ions and drug/growth factors. J Control Release. 2014;193:282-95. https://doi.org/10.1016/j. jconrel.2014.04.026.

54. Mouriño V, Vidotto R, Cattalini JP, Boccaccini AR. Enhancing biological activity of bioactive glass scaffolds by inorganic ion delivery for bone tissue engineering. Curr Opin Biomed Eng. 2019;10:23-34. https://doi.org/10.1016/j.cobme.2019.02.002.

55. Koeberl C, Bayer PM. Concentrations of rare earth elements in human brain tissue and kidney stones determined by neutron activation analysis. J Alloy Compd. 1992;180:63-70. https:// linkinghub.elsevier.com/retrieve/pii/092583889290363E.

56. Fan Y, Huang S, Jiang J, Li G, Yang P, Lian H, et al. Luminescent, mesoporous, and bioactive europium-doped calcium silicate (MCS: Eu3+) as a drug carrier. J Colloid Interface Sci. 2011;357:280-5. https://linkinghub.elsevier.com/retrieve/pii/ S0021979711001639.

57. Zhang Y, Hu M, Wang X, Zhou Z, Liu Y. Design and evaluation of europium containing mesoporous bioactive glass nanospheres: doxorubicin release kinetics and inhibitory effect on osteosarcoma MG 63 cells. Nanomaterials. 2018;8:961. http://www. mdpi.com/2079-4991/8/11/961.

58. Fan Y, Yang P, Huang S, Jiang J, Lian H, Lin J. Luminescent and mesoporous europium-doped bioactive glasses (MBG) as a drug carrier. J Phys Chem C. 2009;113:7826-30. https://doi.org/ 10.1021/jp900515x.

59. Huang S, Kang X, Cheng Z, Ma P, Jia Y, Lin J. Electrospinning preparation and drug delivery properties of $\mathrm{Eu} 3+/ \mathrm{Tb} 3+$ doped mesoporous bioactive glass nanofibers. J Colloid Interface Sci. 2012;387:285-91. https://linkinghub.elsevier.com/retrieve/pii/ S002197971200896X.

60. Xue Y, Du Y, Yan J, Liu Z, Ma PX, Chen X, et al. Monodisperse photoluminescent and highly biocompatible bioactive glass nanoparticles for controlled drug delivery and cell imaging. $\mathbf{J}$ Mater Chem B. 2015;3:3831-9. http://xlink.rsc.org/?DOI= C5TB00204D.

61. Niu W, Guo Y, Xue Y, Wang M, Chen M, Winston DD, et al. Biodegradable multifunctional bioactive Eu-Gd-Si-Ca glass nanoplatform for integrative imaging-targeted tumor therapyrecurrence inhibition-tissue repair. Nano Today. 2021;38:101137 https://linkinghub.elsevier.com/retrieve/pii/ S1748013221000621.

62. Chen M, Wang M, Niu W, Cheng W, Guo Y, Wang Y, et al. Multifunctional protein-decorated bioactive glass nanoparticles for tumor-specific therapy and bioimaging in vitro and in vivo. ACS Appl Mater Interfaces. 2021;13:14985-94. https://pubs.acs. org/doi/abs/10.1021/acsami.1c01337.

63. Divina R, Naseer KA, Marimuthu K, Alajerami YSM, Al-Buriahi MS. Effect of different modifier oxides on the synthesis, structural, optical, and gamma/beta shielding properties of bismuth lead borate glasses doped with europium. J Mater Sci Mater Electron. 2020;31:21486-501. https://doi.org/10.1007/ s10854-020-04662-3.

64. Miao G, Chen X, Mao C, Li X, Li Y, Lin C. Synthesis and characterization of europium-containing luminescent bioactive glasses and evaluation of in vitro bioactivity and cytotoxicity. $\mathbf{J}$
Sol-Gel Sci Technol. 2014;69:250-9. https://doi.org/10.1007/ s10971-013-3209-0.

65. Srinivasa Rao C, Upendra Kumar K, Jayasankar CK. Luminescence properties of Eu3+ ions in phosphate-based bioactive glasses. Solid State Sci. 2011;13:1309-14. https://doi.org/10. 1016/j.solidstatesciences.2011.03.027.

66. Krebs JK, Brownstein JM. Site-selective spectroscopy of Eu3+ in bioactive glass. J Lumin. 2007;124:257-9. https://linkinghub. elsevier.com/retrieve/pii/S002223130600442X.

67. Krebs JK, Brownstein JM, Gibides JT. Decay dynamics of europium excited states in bioactive glasses. J Lumin. 2008;128:780-2. https://linkinghub.elsevier.com/retrieve/pii/ S0022231307004656.

68. Zaki RM, Strutynski C, Kaser S, Bernard D, Hauss G, Faessel $\mathrm{M}$, et al. Direct 3D-printing of phosphate glass by fused deposition modeling. Mater Des. 2020;194:108957. https:// linkinghub.elsevier.com/retrieve/pii/S0264127520304913.

69. Shi M, Xia L, Chen Z, Lv F, Zhu H, Wei F, et al. Europiumdoped mesoporous silica nanosphere as an immune-modulating osteogenesis/angiogenesis agent. Biomaterials 2017;144:176-87. https://doi.org/10.1016/j.biomaterials.2017.08.027.

70. Wu C, Xia L, Han P, Mao L, Wang J, Zhai D, et al. Europiumcontaining mesoporous bioactive glass scaffolds for stimulating in vitro and in vivo osteogenesis. ACS Appl Mater Interfaces. 2016;8:11342-54. https://pubs.acs.org/doi/10.1021/acsami. $6 \mathrm{~b} 03100$.

71. Baranowska A, Lesniak M, Kochanowicz M, Zmojda J, Miluski P, Dorosz D. Crystallization kinetics and structural properties of the 45S5 bioactive glass and glass-ceramic fiber doped with Eu3 +. Materials (Basel) 2020;13:1281. https://pubmed.ncbi.nlm.nih. gov/32178342/.

72. Borak B, Krzak J, Ptak M, Strek W, Lukowiak A. Spherical nanoparticles of europium-doped silica-calcia glass and glassceramic: spectroscopic characterization. J Mol Struct. 2018;1166:48-53. https://linkinghub.elsevier.com/retrieve/pii/ S0022286018304502.

73. Li F, Wang M, Pi G, Lei B. Europium doped monodispersed bioactive glass nanoparticles regulate the osteogenic differentiation of human marrow mesenchymal stem cells. J Biomed Nanotechnol. 2018;14:756-64. http://www.ingentaconnect.com/ content/10.1166/jbn.2018.2504.

74. Li G, Liang G, Zhao S, Ma K, Feng W, Zhou D, et al. Synthesis and characterisation of porous luminescent glass ceramic scaffolds containing europium for bone tissue engineering. Adv Appl Ceram 2015;114:164-74. https://www.tandfonline.com/doi/abs/ 10.1179/1743676114Y.0000000210.

75. Rim KT, Koo KH, Park JS. Toxicological evaluations of rare earths and their health impacts to workers: a literature review. Saf Health Work. 2013;4:12-26. https://doi.org/10.5491/SHAW. 2013.4.1.12.

76. Poniedzialek B, Rzymski P, Piet M, Niedzielski P, Mleczek M, Wilczak M, et al. Rare-earth elements in human colostrum milk. Environ Sci Pollut Res. 2017;24:26148-54. http://link.springer. com/10.1007/s11356-017-0359-6.

77. Nogueira LB, Campos TPR. Synthesis, chemical characterization and radiological response of Ho and HoZr bioglass seeds. J SolGel Sci Technol. 2016;77:688-98. https://link.springer.com/a rticle/10.1007/s10971-015-3900-4.

78. Delpino GP, Borges R, Zambanini T, Joca JFS, Gaubeur I, de Souza ACS, et al. Sol-gel-derived 58S bioactive glass containing holmium aiming brachytherapy applications: a dissolution, bioactivity, and cytotoxicity study. Mater Sci Eng C. 2021;119:111595 https://doi.org/10.1016/j.msec.2020.111595.

79. Zambanini T, Borges R, de Souza ACS, Justo GZ, Machado J, de Araujo DR, et al. Holmium-containing bioactive glasses dispersed in poloxamer 407 hydrogel as a theragenerative 
composite for bone cancer treatment. Materials (Basel) 2021;14:1459 https://www.mdpi.com/1996-1944/14/6/1459.

80. Hosseini SH, Enferadi M, Sadeghi M. Dosimetric aspects of 166 Ho brachytherapy biodegradable glass seed. Appl Radiat Isot. 2013;73:109-15. https://linkinghub.elsevier.com/retrieve/ pii/S0969804312005830.

81. Zaichick S, Zaichick V, Karandashev V, Nosenko S. Accumulation of rare earth elements in human bone within the lifespan. Metallomics. 2011;3:186-94. https://academic.oup.com/meta llomics/article/3/2/186-194/6016253.

82. Tedeschi E, Caranci F, Giordano F, Angelini V, Cocozza S, Brunetti A. Gadolinium retention in the body: what we know and what we can do. Radio Med. 2017;122:589-600. https://doi.org/ 10.1007/s11547-017-0757-3.

83. Feng L, He X, Xiao H, Li Z, Li F, Liu N, et al. Ytterbium and trace element distribution in brain and organic tissues of offspring rats after prenatal and postnatal exposure to ytterbium. Biol Trace Elem Res. 2007;117:89-104. https://doi.org/10.1007/ BF02698086.

84. Borges R, Schneider JF, Marchi J. Structural characterization of bioactive glasses containing rare earth elements ( $\mathrm{Gd}$ and/or $\mathrm{Yb}$ ). J Mater Sci. 2019;54:11390-9. https://doi.org/10.1007/s10853019-03715-1.

85. Zambanini T, Borges R, Faria PC, Delpino GP, Pereira IS, Marques MM, et al. Dissolution, bioactivity behavior, and cytotoxicity of rare earth-containing bioactive glasses $(\mathrm{RE}=\mathrm{Gd}$, Yb). Int J Appl Ceram Technol. 2019;16:2028-39. https://doi. org/10.1111/ijac.13317.

86. Borges R, Menezes NDR, Marchi J. The influence of gadolinium on the thermal properties of bioactive glasses. Biomed Glas. 2019;5:193-202. https://doaj.org/article/ccdbd47fb35d48c0bfea 69b40a6914ce.

87. Mariselvam K. Gamma-ray interactions with ytterbium ions doped BLFB glasses for shielding applications. Optik. 2021;240:166808. https://linkinghub.elsevier.com/retrieve/pii/ S0030402621005167.

88. Li X, Li Q, Wang C, Ni J, Zhang M, Chang J, et al. Fabrication and up-conversion fluorescence property of $\mathrm{Er} 3+/ \mathrm{Yb} 3+\mathrm{co}-$ doped Ca-Si-Ti biomaterials. Mater Res Express. 2019;6:045205 https://iopscience.iop.org/article/10.1088/2053-1591/aafb41.

89. Zhu DY, Lu B, Yin JH, Ke QF, Xu H, Zhang CQ, et al. Gadolinium-doped bioglass scaffolds promote osteogenic differentiation of hBMSC via the Akt/GSK3 $\beta$ pathway and facilitate bone repair in vivo. Int $\mathbf{J}$ Nanomed. 2019;14:1085-100. https://www.dovepress.com/gadolinium-doped-bioglass-sca ffolds-promote-osteogenic-differentiation-peer-reviewed-articleIJN.

90. Liao F, Peng XY, Yang F, Ke QF, Zhu ZH, Guo YP. Gadolinium-doped mesoporous calcium silicate/chitosan scaffolds enhanced bone regeneration ability. Mater Sci Eng C. 2019;104:109999 https://doi.org/10.1016/j.msec.2019.109999.

91. Halubek-Gluchowska K, Szymanski D, Tran TNL, Ferrari M, Lukowiak A. Upconversion luminescence of silica-calcia nanoparticles Co-doped with Tm3+ and Yb3+ ions. Materials (Basel). 2021;14:937 https://www.mdpi.com/1996-1944/14/4/ 937/htm.

92. Chellan P, Sadler PJ. The elements of life and medicines. Philos Trans R Soc A Math Phys Eng Sci. 2015;373:20140182 https:// doi.org/10.1098/rsta.2014.0182.

93. Baranowska A, Kochanowicz M, Zmojda J, Miluski P, Wajda A, Lesniak $M$, et al. Biological properties of rare-earth doped bioactive glass. In: Romaniuk RS, Dorosz J, editors. Optical fibers and their applications 2020. Bialowieza: SPIE; 2020. p. 10. https://www.spiedigitallibrary.org/conference-proceedings-ofspie/11456/2566347/Biological-properties-of-rare-earth-dopedbioactive-glass/10.1117/12.2566347.full.
94. Roberto WS, Pereira M, Campos TPR. Dosimetric analysis and characterisation of radioactive seeds produced by the sol-gel method. Key Eng Mater. 2003;240-242:579-82. https://www. scientific.net/KEM.240-242.579.

95. Roberto WS, Pereira MM, Campos TPR. Structure and dosimetric analysis of biodegradable glasses for prostate cancer treatment. Artif Organs. 2003;27:432-6. https://pubmed.ncbi. nlm.nih.gov/12752203/.

96. Baranowska A, Kochanowicz M, Dorosz J, Dabrowski JR. Effect of biodegradation on spectroscopic properties of $\mathrm{Sm} 3+$ doped 45S5 bioglass. In: Romaniuk RS, Linczuk M, editors. Photonics applications in astronomy, communications, industry, and highenergy physics experiments 2018. Wilga: SPIE; 2018. p. 18. https://www.spiedigitallibrary.org/conference-proceedings-ofspie/10808/2500274/Effect-of-biodegradation-on-spectroscopicproperties-of-Sm3-doped-45S5/10.1117/12.2500274.full.

97. Ershad M, Vyas VK, Prasad S, Ali A, Pyare R. Effect of Sm2O3 substitution on mechanical and biological properties of 45S5 bioactive glass. J Aust Ceram Soc. 2018;54:621-30. https://doi. org/10.1007/s41779-018-0190-7.

98. Zhang Y, Wang X, Su Y, Chen D, Zhong W. A doxorubicin delivery system: Samarium/mesoporous bioactive glass/alginate composite microspheres. Mater Sci Eng C. 2016;67:205-13. https://doi.org/10.1016/j.msec.2016.05.019.

99. Morais DS, Coelho J, Ferraz MP, Gomes PS, Fernandes MH, Hussain NS, et al. Samarium doped glass-reinforced hydroxyapatite with enhanced osteoblastic performance and antibacterial properties for bone tissue regeneration. J Mater Chem B. 2014;2:5872-81. http://xlink.rsc.org/?DOI=C4TB00484A.

100. Simon S, Cacaina D, Vasilescu M, Ylänen H, Hupa M. MASNMR support for Hench model in the case of bioactive glass microspheres. J Mater Sci. 2017;52:8998-9005. https://doi.org/ 10.1007/s10853-017-1058-x.

101. Ben-Arfa BAE, Salvado IMM, Ferreira JMF, Pullar RC. The effect of functional ions ( $\mathrm{Y} 3+, \mathrm{F}-, \mathrm{Ti} 4+)$ on the structure, sintering and crystallization of diopside-calcium pyrophosphate bioglasses. J Non Cryst Solids. 2016;443:162-71. https://doi.org/ 10.1016/j.jnoncrysol.2016.04.028.

102. Cacaina D, Ylänen H, Udvar DA, Simon S, Kogalniceanu M. EPR study of gamma irradiated yttrium bioactive glasses and yttrium silica sol-gel microspheres. J Optoelectron Adv Mater. 2007;9:675-9. https://www.semanticscholar.org/paper/EPRstudy-of-gamma-irradiated-yttrium-bioactive-and-Cacaina-Y1\% C3\%A4nen/3d1d046ad5cff84229996c046891e3adda8f83ed.

103. Cacaina D, Ylänen H, Simon S, Hupa M. The behaviour of selected yttrium containing bioactive glass microspheres in simulated body environments. J Mater Sci Mater Med. 2008;19:1225-33. https://pubmed.ncbi.nlm.nih.gov/ $17701304 /$.

104. Lee EMR, Borges R, Marchi J, Paula Eduardo C, Marques MM. Bioactive glass and high-intensity lasers as a promising treatment for dentin hypersensitivity: an in vitro study. J Biomed Mater Res Part B Appl Biomater. 2020;108:939-47. https://pubmed. ncbi.nlm.nih.gov/31381257/

105. Hadush Tesfay A, Chou YJ, Tan CY, Fufa Bakare F, Tsou NT, Huang EW, et al. Control of dopant distribution in yttrium-doped bioactive glass for selective internal radiotherapy applications using spray pyrolysis. Materials (Basel). 2019;12:986 https://www.mdpi.com/1996-1944/12/6/986.

106. Cacaina D, Viitala R, Jokinen M, Ylänen HO, Hupa M, Simon S. In vitro behavior of yttrium silica sol-gel microspheres. Key Eng Mater. 2005;284-286:411-4. https://www.scientific.net/KEM. 284-286.411.

107. Vasanthavel S, Meenakshi K, Nivedha V, Ballamurugan AM, Kannan S. Tuning the structural and mechanical properties in $\mathrm{ZrO} 2-\mathrm{SiO} 2$ binary system through $\mathrm{Y} 3+$ inclusions. Mater Sci 
Eng C. 2018;84:230-5. https://pubmed.ncbi.nlm.nih.gov/ 29519433/.

108. Placek LM, Keenan TJ, Wren AW. Bioactivity of Y2O3 and $\mathrm{CeO} 2$ doped $\mathrm{SiO} 2-\mathrm{SrO}-\mathrm{Na} 2 \mathrm{O}$ glass-ceramics. J Biomater Appl. 2016;31:165-80. https://pubmed.ncbi.nlm.nih.gov/27231265/.

109. Farmakis E-TR, Kozyrakis K, Khabbaz MG, Schoop U, Beer F, Moritz A. In vitro evaluation of dentin tubule occlusion by denshield and neodymium-doped yttrium-aluminum-garnet laser irradiation. J Endod. 2012;38:662-6. https://pubmed.ncbi.nlm. nih.gov/22515897/.

110. Christie JK, Tilocca A. Integrating biological activity into radioisotope vectors: molecular dynamics models of yttriumdoped bioactive glasses. J Mater Chem. 2012;22:12023 http:// xlink.rsc.org/?DOI $=$ c2jm31561k.

111. Erbe EM, Day DE. Chemical durability of Y2O3-A12O3-SiO2 glasses for thein vivo delivery of beta radiation. J Biomed Mater Res. 1993;27:1301-8. https://onlinelibrary.wiley.com/doi/10. 1002/jbm.820271010.

112. Christie JK, Malik J, Tilocca A. Bioactive glasses as potential radioisotope vectors for in situ cancer therapy: investigating the structural effects of yttrium. Phys Chem Chem Phys. 2011;13:17749 http://xlink.rsc.org/?DOI=c1cp21764j.

113. Arafat A, Samad SA, Titman JJ, Lewis AL, Barney ER, Ahmed I. Yttrium doped phosphate-based glasses: structural and degradation analyses. Biomed Glas 2020;6:34-49. https://www. degruyter.com/document/doi/10.1515/bglass-2020-0004/html.

114. Thyparambil NJ, Gutgesell LC, Hurley CC, Flowers LE, Day DE, Semon JA. Adult stem cell response to doped bioactive borate glass. J Mater Sci Mater Med. 2020;31:13. https://doi.org/ 10.1007/s10856-019-6353-4.

115. Bronner F. Chapter 25 - Metals in bone: aluminum, boron, cadmium, chromium, lanthanum, lead, silicon, and strontium. In: Bilezikian J, Raisz L, Martin TJ, editors. Principles of bone biology. Elsevier; 2008. p. 515-31. https://linkinghub.elsevier. com/retrieve/pii/B9780123738844000446.

116. Youness RA, Taha MA, Ibrahim M, El-Kheshen A. FTIR spectral characterization, mechanical properties and antimicrobial properties of La-doped phosphate-based bioactive glasses. Silicon. 2018;10:1151-9. https://doi.org/10.1007/ s12633-017-9587-0.

117. Zhu D, Lu B, Yang Q, Yu H, Liu P, Yin J, et al. Lanthanumdoped mesoporous bioglasses/chitosan composite scaffolds enhance synchronous osteogenesis and angiogenesis for augmented osseous regeneration. Chem Eng J. 2021;405:127077 https://doi.org/10.1016/j.cej.2020.127077.

118. El-Meliegy E, Farag MM, El-Kady AM, Mohamed MS, Abdelhakim HK, Moaness M. Evaluation of solubility and cytotoxicity of lanthanum-doped phosphate glasses nanoparticles for drug delivery applications. J Non Cryst Solids. 2017;475:5970. https://doi.org/10.1016/j.jnoncrysol.2017.08.034.

119. Liying L, Zhao D, Zhang Z, Zhang X. Adsorption and photocatalyst of methylene blue on mesoporous bioactive glass with La and Ti dopants. Glas Phys Chem. 2021;47:143-53. https:// doi.org/10.1134/S1087659621020073.

120. Ben-Arfa BAE, Miranda Salvado IM, Ferreira JMF, Pullar RC. The effects of $\mathrm{Cu} 2+$ and $\mathrm{La} 3+$ doping on the sintering ability of sol-gel derived high silica bioglasses. Ceram Int. 2019;45:10269-78. https://linkinghub.elsevier.com/retrieve/pii/ S0272884219303815.

121. Khoshsima S, Alshemary A, Tezcaner A, Surdem S, Evis Z. Impact of $\mathrm{B} 2 \mathrm{O} 3$ and $\mathrm{La} 2 \mathrm{O} 3$ addition on structural, mechanical and biological properties of hydroxyapatite. Process Appl Ceram. 2018;12:143-52. http://www.doiserbia.nb.rs/Article. aspx $? \mathrm{ID}=1820-61311802143 \mathrm{~K}$.

122. Ershad M, Ali A, Mehta NS, Singh RK, Singh SK, Pyare R. Mechanical and biological response of $(\mathrm{CeO} 2+\mathrm{La} 2 \mathrm{O} 3)-$ substituted $45 \mathrm{~S} 5$ bioactive glasses for biomedical application. J Aust Ceram Soc. 2020;56:1243-52. https://link.springer.com/10. 1007/s41779-020-00471-3.

123. Ben-Arfa BAE, Palamá IE, Miranda Salvado IM, Ferreira JMF, Pullar RC. Cytotoxicity and bioactivity assessments for $\mathrm{Cu} 2+$ and $\mathrm{La} \mathrm{3}$ + doped high-silica sol-gel derived bioglasses: the complex interplay between additive ions revealed. J Biomed Mater Res Part A. 2019;107:2680-93. https://onlinelibrary. wiley.com/doi/10.1002/jbm.a.36772.

124. Ben-Arfa BAE, Neto S, Miranda Salvado IM, Pullar RC, Ferreira JMF. Robocasting of $\mathrm{Cu} 2+\& \mathrm{La} 3+$ doped sol-gel glass scaffolds with greatly enhanced mechanical properties: compressive strength up to $14 \mathrm{MPa}$. Acta Biomater. 2019;87:265-72. https://linkinghub.elsevier.com/retrieve/pii/ S1742706119300704.

125. Jodati H, Güner B, Evis Z, Keskin D, Tezcaner A. Synthesis and characterization of magnesium-lanthanum dual doped bioactive glasses. Ceram Int. 2020;46:10503-11. https://linkinghub. elsevier.com/retrieve/pii/S0272884220300511.

126. Deliormanli AM, Issa SAM, Al-Buriahi MS, Rahman B, Zakaly $\mathrm{HMH}$, Tekin HO. Erbium (III)- and Terbium (III)-containing silicate-based bioactive glass powders: physical, structural and nuclear radiation shielding characteristics. Appl Phys A. 2021;127:463. https://link.springer.com/article/10.1007/s00339021-04615-5

127. Lopez-Iscoa P, Ojha N, Pugliese D, Mishra A, Gumenyuk R, Boetti NG, et al. Design, processing, and characterization of an optical core-bioactive clad phosphate fiber for biomedical applications. J Am Ceram Soc. 2019;102:6882-92. https://cera mics.onlinelibrary.wiley.com/doi/full/10.1111/jace.16553

128. Li Q, Xing M, Chen Z, Wang X, Zhao C, Qiu J, et al. Er 3+/Yb $3+$ co-doped bioactive glasses with up-conversion luminescence prepared by containerless processing. Ceram Int. 2016;42:13168-75. https://linkinghub.elsevier.com/retrieve/pii/ S0272884216307155.

129. Li X, Li Y, Chen X, Li B, Gao B, Ren Z, et al. Optically monitoring mineralization and demineralization on photoluminescent bioactive nanofibers. Langmuir. 2016;32:3226-33. https://pubs.acs.org/doi/pdf/10.1021/acs.langmuir.6b00290

130. Wang X, Zhang Y, Lin C, Zhong W. Sol-gel derived terbiumcontaining mesoporous bioactive glasses nanospheres: In vitro hydroxyapatite formation and drug delivery. Colloids Surf B Biointerfaces. 2017;160:406-15. https://doi.org/10.1016/j. colsurfb.2017.09.051.

131. Li Q, Xing M, Chang L, Ma L, Chen Z, Qiu J, et al. Upconversion luminescence $\mathrm{Ca}-\mathrm{Mg}-\mathrm{Si}$ bioactive glasses synthesized using the containerless processing technique. Front Mater Sci. 2019;13:399-409. http://link.springer.com/10.1007/s11706-0190484-x.

132. Deliormanli AM, Rahman B, Oguzlar S, Ertekin K. Structural and luminescent properties of Er3+ and Tb3+-doped sol-gelbased bioactive glass powders and electrospun nanofibers. J Mater Sci. 2021;56:14487-504. https://link.springer.com/10. 1007/s10853-021-06203-7.

133. Conzone SD, Day DE. Preparation and properties of porous microspheres made from borate glass. J Biomed Mater Res Part A 2009;88:531-42. https://doi.org/10.1002/jbm.a.31883.

134. Day DE, White JE, Brown RF, McMenamin KD. Transformation of borate glasses into biologically useful materials. Glas Technol. 2003;44:75-81. https://scholarsmine.mst.edu/biosci_fa cwork/42/.

135. Patcas L, Vanea E, Tamasan M, Eniu D, Simon V. Nanostructural changes induced by thermal treatment of calcium-silicate glasses containing dysprosium and iron. Optoelectron Adv Mater Rapid Commun. 2014;8:989-92. https://oam-rc.inoe.ro/a rticles/nanos-tructural-changes-induced-by-thermal-treatment-of- 
calcium-silicate-glasses-containing-dysprosium-and-iron/ fulltext.

136. Soetan KO, Olaiya CO, Oyewole OE. The importance of mineral elements for humans, domestic animals and plants: a review. Afr J Food Sci. 2010;4:200-22. https://www.google.com/url?sa= $\mathrm{t} \& \mathrm{rct}=\mathrm{j} \& \mathrm{q}=\& \mathrm{esrc}=\mathrm{s} \&$ source $=$ web $\& \mathrm{~cd}=\& \mathrm{cad}=\mathrm{rja} \&$ uact $=$ $8 \&$ ved $=2$ ahUKEw iLqrWjlvT0AhXDxDgGHbAEBkcQFnoECAIQAQ\&url=https $\% 3 \mathrm{~A} \% 2 \mathrm{~F} \% 2$ Facademicjournals.org $\% 2 \mathrm{Farticle} \% 2 \mathrm{Fa}$ rticle1380713863_Soetan\%2520et\%2520al.pdf\&usg=AOvVaw 1J2YpTgMuY_nTzKtBDfeLj.

137. Yukawa M, Suzuki-Yasumoto M, Amano K, Terai M. Distribution of trace elements in the human body determined by neutron activation analysis. Arch Environ Heal Int J. 1980;35:36-44. http://www.tandfonline.com/doi/abs/10.1080/ 00039896.1980 .10667459 .

138. Yamagata N. The concentration of common cesium and rubidium in human body. J Radiat Res. 1962;3:9-30. https://aca demic.oup.com/jrr/article-lookup/doi/10.1269/jrr.3.9.

139. Tan YN, Chen WJ, Wei W, Huang QL, He X. Rubidium-modified bioactive glass-ceramics with hydroxyapatite crystals for bone regeneration. Trans Nonferrous Met Soc China. 2021;31:521-32. https://linkinghub.elsevier.com/retrieve/pii/ S1003632621655140

140. Ouyang S, Zheng K, Huang Q, Liu Y, Boccaccini AR. Synthesis and characterization of rubidium-containing bioactive glass nanoparticles. Mater Lett. 2020;273:127920. https://doi.org/10. 1016/j.matlet.2020.127920.

141. He X, Ding Y, Duan S, Luo S, Song J, Peng C, et al. Wound dressings based on rubidium-doped bioactive glass nanospheres promote diabetic wound healing. J Biomed Nanotechnol. 2019;15:2059-71. https://www.ingentaconnect.com/content/10. 1166/jbn.2019.2849.

142. He X, Liu Y, Tan Y, Grover LM, Song J, Duan S, et al. Rubidium-containing mesoporous bioactive glass scaffolds support angiogenesis, osteogenesis and antibacterial activity. Mater Sci Eng C. 2019;105:110155 https://doi.org/10.1016/j.msec.2019. 110155. December 2018

143. Schroeder HA, Tipton IH, Nason AP. Trace metals in man: strontium and barium. J Chronic Dis. 1972;25:491-517. https:// linkinghub.elsevier.com/retrieve/pii/0021968172901506.

144. Oskarsson A. Barium. In: Nordberg GF, Fowler BA, Nordberg $M$, editors. Handbook on the toxicology of metals. Elsevier; 2015. p. 625-34. https://linkinghub.elsevier.com/retrieve/pii/ B9780444594532000299.

145. Shokrollahi H, Salimi F, Doostmohammadi A. The fabrication and characterization of barium titanate/akermanite nano-bioceramic with a suitable piezoelectric coefficient for bone defect recovery. J Mech Behav Biomed Mater. 2017;74:365-70. https:// pubmed.ncbi.nlm.nih.gov/28672271/

146. Tanaka CB, Lopes DP, Kikuchi LNT, Moreira MS, Catalani LH, Braga RR, et al. Development of novel dental restorative composites with dibasic calcium phosphate loaded chitosan fillers. Dent Mater. 2020;36:551-9. https://linkinghub.elsevier.com/ retrieve/pii/S0109564120300385

147. Hasan MS, Kehoe S, Boyd D. Temporal analysis of dissolution by-products and genotoxic potential of spherical zinc-silicate bioglass: "Imageable beads" for transarterial embolization. J Biomater Appl. 2014;29:566-81. https://pubmed.ncbi.nlm.nih. gov/24913613/.

148. Huang TY, Su WT, Chen PH. Comparing the effects of chitosan scaffolds containing various divalent metal phosphates on osteogenic differentiation of stem cells from human exfoliated deciduous teeth. Biol Trace Elem Res.2018;185:316-26. https:// pubmed.ncbi.nlm.nih.gov/29399740/.
149. Par M, Šantic A, Gamulin O, Marovic D, Moguš-Milankovic A, Tarle Z. Impedance changes during setting of amorphous calcium phosphate composites. Dent Mater. 2016;32:1312-21. https://pubmed.ncbi.nlm.nih.gov/27524232/.

150. Natale LC, Rodrigues MC, Alania Y, Chiari MDS, Boaro LCC, Cotrim M, et al. Mechanical characterization and ion release of bioactive dental composites containing calcium phosphate particles. J Mech Behav Biomed Mater. 2018;84:161-7. https:// linkinghub.elsevier.com/retrieve/pii/S1751616118304429.

151. Bilandžic MD, Roos C, Braun A, Jansen P. Development of a radiopaque dental glass for endodontic laser applications. J Mater Res Technol. 2020;9:13994-4001. https://linkinghub.elsevier. com/retrieve/pii/S2238785420318172.

152. Saeidi B, Derakhshandeh MR, Delshad Chermahini M, Doostmohammadi A. Novel porous barium titanate/nano-bioactive glass composite with high piezoelectric coefficient for bone regeneration applications. J Mater Eng Perform. 2020;29:5420 7. https://doi.org/10.1007/s11665-020-05016-0.

153. Arepalli SK, Tripathi H, Vyas VK, Jain S, Suman SK, Pyare R, et al. Influence of barium substitution on bioactivity, thermal and physico-mechanical properties of bioactive glass. Mater Sci Eng C. 2015;49:549-59. https://linkinghub.elsevier.com/retrieve/pii/ S0928493115000594.

154. Yazdanpanah A, Moztarzadeh F. Synthesis and characterization of Barium-Iron containing magnetic bioactive glasses: the effect of magnetic component on structure and in vitro bioactivity. Colloids Surf B Biointerfaces. 2019;176:27-37. https://doi.org/ 10.1016/j.colsurfb.2018.12.036.

155. Kaur G, Sharma P, Kumar V, Singh K. Assessment of in vitro bioactivity of $\mathrm{SiO} 2-\mathrm{BaO}-\mathrm{ZnO}-\mathrm{B} 2 \mathrm{O} 3-\mathrm{Al} 2 \mathrm{O} 3$ glasses: an opticoanalytical approach. Mater Sci Eng C. 2012;32:1941-7. https:// linkinghub.elsevier.com/retrieve/pii/S0928493112002548

156. Altaie A, Bubb N, Franklin P, German MJ, Marie A, Wood DJ. Development and characterisation of dental composites containing anisotropic fluorapatite bundles and rods. Dent Mater. 2020;36:1071-85. https://pubmed.ncbi.nlm.nih.gov/32513479/.

157. El-Meliegy EM, Hamzawy EMA. Celsian-fluorophlogopite porcelain based on Egyptian talc. Adv Appl Ceram. 2005;104:92-6. https://doi.org/10.1179/174367605X16590.

158. Alania Y, Chiari MDS, Rodrigues MC, Arana-Chavez VE, Bressiani AHA, Vichi FM, et al. Bioactive composites containing TEGDMA-functionalized calcium phosphate particles: degree of conversion, fracture strength and ion release evaluation. Dent Mater. 2016;32:e374-81. https://linkinghub.elsevier. com/retrieve/pii/S0109564116304031

159. Paliwal P, Kumar AS, Tripathi H, Singh SP, Patne SCU, Krishnamurthy S. Pharmacological application of barium containing bioactive glass in gastro-duodenal ulcers. Mater Sci Eng C. 2018;92:424-34. https://doi.org/10.1016/j.msec.2018.06.068.

160. Zakaly HMH, Saudi HA, Issa SAM, Rashad M, Elazaka AI, Tekin HO, et al. Alteration of optical, structural, mechanical durability and nuclear radiation attenuation properties of barium borosilicate glasses through $\mathrm{BaO}$ reinforcement: experimental and numerical analyses. Ceram Int. 2021;47:5587-96. https:// doi.org/10.1016/j.ceramint.2020.10.143.

161. Qian H, Lei T, Ye Z, Hu Y, Lei P. From the performance to the essence: the biological mechanisms of how tantalum contributes to osteogenesis. Biomed Res Int. 2020;2020:1-8. https://www. hindawi.com/journals/bmri/2020/5162524/.

162. Nagrath M, Gallant R, Yazdi AR, Mendonca A, Rahman S, Chiu $\mathrm{L}$, et al. Tantalum-containing mesoporous bioactive glass powder for hemostasis. J Biomater Appl. 2021;35:924-32. https://journa 1s.sagepub.com/doi/full/10.1177/0885328220965150.

163. Kamitakahara M, Kawashita M, Miyata N, Kokubo T, Nakamura T. Preparation of bioactive flexible poly(tetramethylene oxide) 
(PTMO)-CaO-Ta2O5 hybrids. J Mater Sci Mater Med. 2007;18:1117-24. https://doi.org/10.1007/s10856-007-0147-9.

164. Wang A, Lin W, Ma J, Shi L, Wang W, He Y, et al. Application of tantalum-containing chitosan scaffolds for the repair of osteoporotic bone defects. Sci Adv Mater. 2018;10:1179-89. https://doi.org/10.1166/sam.2018.3282.

165. Madhavi B, Reddy ASS, Prasad PS, Mohan Babu M, Rao PR, Kumar VR, et al. In-vitro bioactivity and antibacterial properties of $\mathrm{CaF} 2-\mathrm{CaO}-\mathrm{B} 2 \mathrm{O} 3-\mathrm{P} 2 \mathrm{O} 5-\mathrm{SrO}$ glass system-influence of Ta2O5. J Non Cryst Solids. 2021;566:120881 https://linkinghub. elsevier.com/retrieve/pii/S0022309321002404.

166. Grishchenko DN, Slobodyuk AB, Kuryavyi VG, Medkov MA. Tantalum-containing bioactive glass-ceramics: a mechanism of suppression of the biological activity of the 45S5 bioglass by doping with Ta2O5. Russ J Inorg Chem. 2020;65:1606-13. https://doi.org/10.1134/S0036023620100083.

167. Nagrath M, Yazdi AR, Rafferty A, Daly D, Rahman SU, Gallant $\mathrm{RC}$, et al. Tantalum-containing meso-porous glass fibres for hemostatic applications. Mater Today Commun. 2021;27:102260 https://linkinghub.elsevier.com/retrieve/pii/ S235249282100252X

168. Medkov MA, Grishchenko DN, Dmitrieva EE, Kudryavyi VG. Obtaining bioactive glasses by the pyrolysis of organic solutions. Theor Found Chem Eng. 2020;54:1005-9. https://doi.org/10. 1134/S0040579520050188.

169. Mendonca A, Rahman MS, Alhalawani A, Rodriguez O, Gallant $\mathrm{RC}, \mathrm{Ni} \mathrm{H}$, et al. The effect of tantalum incorporation on the physical and chemical properties of ternary silicon-calciumphosphorous mesoporous bioactive glasses. J Biomed Mater Res Part B Appl Biomater. 2019;107:2229-37. https://doi.org/10. 1002/jbm.b.34310.

170. Alalawi A. Optical features and nuclear radiation shielding efficiency of ZnO-B2O3-Ta2O5 glasses. Phys Scr. 2020;95:105302 https://doi.org/10.1088/1402-4896/abb49d.

171. Madanat R, Moritz N, Vedel E, Svedström E, Aro HT. Radioopaque bioactive glass markers for radiostereometric analysis. Acta Biomater. 2009;5:3497-505. https://linkinghub.elsevier. com/retrieve/pii/S1742706109002591

172. Alhalawani AM, Mehrvar C, Stone W, Waldman SD, Towler MR. A novel tantalum-containing bioglass. Part II. Development of a bioadhesive for sternal fixation and repair. Mater Sci Eng C. 2017;71:401-11. https://pubmed.ncbi.nlm.nih.gov/27987724/.

173. Tabia Z, Akhtach S, El Mabrouk K, Bricha M, Nouneh K, Ballamurugan A. Tantalum doped $\mathrm{SiO} 2-\mathrm{CaO}-\mathrm{P} 2 \mathrm{O} 5$ based bioactive glasses: investigation of in vitro bioactivity and antibacterial activities. Biomed Glas. 2020;6:10-22. https://www. degruyter.com/document/doi/10.1515/bglass-2020-0002/html.

174. Samudrala RK, Azeem PA. Preliminary biological evaluation of tantalum containing soda lime borosilicate bioactive glasses. J Alloy Compd. 2019;810:151853 https://doi.org/10.1016/j.ja llcom.2019.151853.

175. Babu MM, Prasad PS, Bindu SH, Rao PV, Govindan NP, Veeraiah N, et al. RETRACTED: bioactivity, antibacterial activity and functionality of zirconia doped zinc phosphate bioglasses for application in dentistry. Mater Sci Eng C. 2020;114:111052 https://doi.org/10.1016/j.msec.2020.111052.

176. Zhang K, Van Le Q. Bioactive glass coated zirconia for dental implants: a review. J Compos Compd. 2020;2:10-7. https:// jourcc.com/index.php/jourcc/article/view/jcc212.

177. Tosiriwatanapong T, Singhatanadgit W. Zirconia-based biomaterials for hard tissue reconstruction. Bone Tissue Regen Insights. 2018;9:1179061X1876788. https://doi.org/10.1177/ $1179061 X 18767886$.

178. Majhi MR, Pyare R, Singh SP. Studies on preparation and characterizations of $\mathrm{CaO}-\mathrm{Na} 2 \mathrm{O}-\mathrm{SiO} 2-\mathrm{P} 2 \mathrm{O} 5$ bioglass ceramics substituted with $\mathrm{A} 12 \mathrm{O} 3, \mathrm{TiO} 2$ and $\mathrm{ZrO} 2$. J Biomater Tissue Eng.
2012;2:154-69. http://openurl.ingenta.com/content/xref? genre $=$ article $\&$ issn $=2157-9083 \&$ volume $=2 \&$ issue $=2 \&$ spage $=$ 154

179. Zohourfazeli M, Tajer MHM, Moghanian A. Comprehensive investigation on multifunctional properties of zirconium and silver co-substituted $58 \mathrm{~S}$ bioactive glass. Ceram Int. 2021;47:2499-507. https://doi.org/10.1016/j.ceramint.2020.09. 093.

180. Moghanian A, Tajer MHM, Zohourfazeli M, Miri Z, Yazdi M. Sol-gel derived silicate-based bioactive glass: Studies of synergetic effect of zirconium and magnesium on structural and biological characteristics. J Non Cryst Solids. 2021;554:120613 https://linkinghub.elsevier.com/retrieve/pii/ S0022309320307237.

181. Kang TY, Seo JY, Ryu JH, Kim KM, Kwon JS. Improvement of the mechanical and biological properties of bioactive glasses by the addition of zirconium oxide $(\mathrm{ZrO} 2)$ as a synthetic bone graft substitute. J Biomed Mater Res Part A. 2021;109:1196-208. https://onlinelibrary.wiley.com/doi/full/10.1002/jbm.a.37113

182. Babu MM, Prasad PS, Rao PV, Bindu SH, Prasad A, Veeraiah $\mathrm{N}$, et al. Influence of $\mathrm{ZrO} 2$ addition on structural and biological activity of phosphate glasses for bone regeneration. Materials (Basel). 2020;13:4058 https://www.mdpi.com/1996-1944/13/18/ 4058/htm

183. Kumar P, Kumar V, Kumar R, Kumar R, Pruncu CI. Fabrication and characterization of $\mathrm{ZrO} 2$ incorporated $\mathrm{SiO} 2-\mathrm{CaO}-\mathrm{P} 2 \mathrm{O} 5$ bioactive glass scaffolds. J Mech Behav Biomed Mater. 2020;109:103854 https://linkinghub.elsevier.com/retrieve/pii/ S1751616120304082.

184. Zhu Y, Zhang Y, Wu C, Fang Y, Yang J, Wang S. The effect of zirconium incorporation on the physiochemical and biological properties of mesoporous bioactive glasses scaffolds. Microporous Mesoporous Mater. 2011;143:311-9. https://linkinghub. elsevier.com/retrieve/pii/S1387181111001132.

185. Rajkumar G, Aravindan S, Rajendran V. Structural analysis of zirconia-doped calcium phosphate glasses. J Non Cryst Solids. 2010;356:1432-8. https://linkinghub.elsevier.com/retrieve/pii/ S0022309310001973.

186. Ploska U, Berger G, Sahre M. Investigation of the influence of zirconium content on the formation of apatite on bioactive glassceramics. Key Eng Mater. 2003;254-256:71-4. https://www. scientific.net/KEM.254-256.71.

187. Lubauer J, Belli R, Petschelt A, Cicconi MR, Hurle K, Lohbauer U. Concurrent kinetics of crystallization and toughening in multicomponent biomedical $\mathrm{SiO} 2-\mathrm{Li} 2 \mathrm{O}-\mathrm{P} 2 \mathrm{O} 5-\mathrm{ZrO} 2$ glass-ceramics. J Non Cryst Solids. 2021;554:120607 https://linkinghub. elsevier.com/retrieve/pii/S0022309320307171.

188. Samudrala R, Reddy GVN, Manavathi B, Azeem PA. Synthesis, characterization and cytocompatibility of $\mathrm{ZrO} 2$ doped borosilicate bioglasses. J Non Cryst Solids. 2016;447:150-5. https:// doi.org/10.1016/j.jnoncrysol.2016.05.001.

189. Lu X, Deng L, Du J. Effect of $\mathrm{ZrO} 2$ on the structure and properties of soda-lime silicate glasses from molecular dynamics simulations. J Non Cryst Solids. 2018;491:141-50. https:// linkinghub.elsevier.com/retrieve/pii/S002230931830200X.

190. Yin P, Yuan JW, Liu LH, Xiao T, Lei T. Effect of ZrO2 on the bioactivity properties of gel-derived $\mathrm{CaO}-\mathrm{P} 2 \mathrm{O} 5-\mathrm{SiO} 2-\mathrm{SrO}$ glasses. Ceram Int. 2017;43:9691-8. https://linkinghub.elsevier.com/ retrieve/pii/S0272884217307514

191. Prabhu M, Kavitha K, Sutha S, Manivasakan P, Rajendran V, Kulandaivelu $\mathrm{P}$, et al. Bioactivity of zirconium-substituted nanobioactive glass particles. Synth React Inorg Met Org Chem. 2014;45:92-6. https://doi.org/10.1080/15533174.2013.819894.

192. Mozafari M, Salahinejad E, Sharifi-Asl S, Macdonald DD, Vashaee D, Tayebi L. Innovative surface modification of orthopaedic implants with positive effects on wettability and in 
vitro anti-corrosion performance. Surf Eng. 2014;30:688-92. https://doi.org/10.1179/1743294414Y.0000000309.

193. Tigunta S, Pisitpipathsin N, Kantha P, Eitssayeam S, Rujijanagul $\mathrm{G}$, Tunkasiri T, et al. Electrical properties of calcium phosphate/ BZT bioglass-ceramics prepared by incorporation method. Ferroelectrics. 2014;459:188-94. https://doi.org/10.1080/00150193. 2013.849527.

194. Pisitpipathsin N, Kantha P, Eitsayeam S, Rujijanakul G, Guo R, Bhalla AS, et al. Effect of BCZT on electrical properties and bioactivity of 45S5 bioglass. Integr Ferroelectr. 2013;142:14453. https://doi.org/10.1080/10584587.2013.780574.

195. Mozafari M, Salahinejad E, Shabafrooz V, Yazdimamaghani M, Vashaee D, Tayebi L. Multilayer bioactive glass/zirconium titanate thin films in bone tissue engineering and regenerative dentistry. Int J Nanomed. 2013;8:1665 https://www.ncbi.nlm. nih.gov/pmc/articles/PMC3639719/.

196. Aguilar CR, Reyes EAA, Martínez MF, Patiño CAL, Anita REN. Synthesis and characterisation of $\beta$-TCP/bioglass/zirconia scaffolds. Adv Appl Ceram. 2017;116:452-61. https://doi.org/ 10.1080/17436753.2017.1356043.

197. Yadav SK, Ray S, Ershad M, Vyas VK, Prasad S, Ali A, et al. Development of zirconia substituted 1393 bioactive glass for orthopaedic application. Orient J Chem. 2017;33:2720-30. http://www.orientjchem.org/vol33no6/development-of-zirconiasubstituted-1393-bioactive-glass-for-orthopaedic-application/.

198. Moghanian A, Zohourfazeli M, Tajer MHM. The effect of zirconium content on in vitro bioactivity, biological behavior and antibacterial activity of sol-gel derived $58 \mathrm{~S}$ bioactive glass. J Non Cryst Solids. 2020;546:120262. https://doi.org/10.1016/j. jnoncrysol.2020.120262.

199. Ginebra MP, Montufar EB. Cements as bone repair materials. In: Pawelec KM, Planell JA, editors. Bone repair biomaterials. 2nd ed. Elsevier; 2019. 233-71. https://doi.org/10.1016/B978-0-08102451-5.00009-3.

200. Bargavi P, Chitra S, Durgalakshmi D, Radha G, Balakumar S. Zirconia reinforced bio-active glass coating by spray pyrolysis: structure, surface topography, in-vitro biological evaluation and antibacterial activities. Mater Today Commun. 2020;25:101253. https://doi.org/10.1016/j.mtcomm.2020.101253.

201. Ali A, Ershad M, Hira S, Pyare R, Singh SP. Mechanochemical and in vitro cytocompatibility evaluation of zirconia modified silver substituted 1393 bioactive glasses. Boletín la Soc Española Cerámica y Vidr. 2020. https://doi.org/10.1016/j.bsecv.2020.07. 002. (In press).

202. Capanema NSV, Mansur AAP, Carvalho SM, Silva ARP, Ciminelli VS, Mansur HS. Niobium-doped hydroxyapatite bioceramics: synthesis, characterization and in vitro cytocompatibility. Materials (Basel). 2015;8:4191-209. http://www.mdpi. com/1996-1944/8/7/4191.

203. Carneiro KK, Araujo TP, Carvalho EM, Meier MM, Tanaka A, Carvalho $\mathrm{CN}$, et al. Bioactivity and properties of an adhesive system functionalized with an experimental niobium-based glass. J Mech Behav Biomed Mater. 2018;78:188-95. https://doi.org/ 10.1016/j.jmbbm.2017.11.016.

204. Leal A, Carvalho C, Filho EM, Neto VM, Carmo M, Maciel A, et al. Airborne-particle abrasion with niobium phosphate bioactive glass on caries-affected dentin: effect on the microtensile bond strength. J Adhes Sci Technol. 2017;31:2410-23. https:// doi.org/10.1080/01694243.2017.1303865.

205. Bonetti L, Altomare L, Bono N, Panno E, Campiglio CE, Draghi $\mathrm{L}$, et al. Electrophoretic processing of chitosan based composite scaffolds with $\mathrm{Nb}$-doped bioactive glass for bone tissue regeneration. J Mater Sci Mater Med. 2020;31:43 https://doi.org/10. 1007/s10856-020-06378-6.

206. DEGRAZIA, Felipe Weidenbach et al. Evaluation of an antibacterial orthodontic adhesive incorporated with niobium-based bioglass: an in situ study. Brazilian Oral Research [online]. 2019;33:e010. https://doi.org/10.1590/1807-3107bor-2019. vol33.0010.

207. Carvalho EM, Lima DM, Carvalho CN, Loguercio AD, Martinelli JR, Bauer J. Effect of airborne-particle abrasion on dentin with experimental niobophosphate bioactive glass on the microtensile bond strength of resin cements. J Prosthodont Res. 2015;59:129-35. https://pubmed.ncbi.nlm.nih.gov/25659301/

208. Bauer J, Carvalho EM, Carvalho CN, Meier MM, Souza JP de, Carvalho RM de, et al. Development of a simplified etch-andrinse adhesive containing niobiophosphate bioactive glass. Int $\mathrm{J}$ Adhes Adhes. 2016;69:110-4. https://linkinghub.elsevier.com/ retrieve/pii/S014374961630063X.

209. Balbinot G de S, Collares FM, Visioli F, Soares PBF, Takimi AS, Samuel SMW, et al. Niobium addition to sol-gel derived bioactive glass powders and scaffolds: in vitro characterization and effect on pre-osteoblastic cell behavior. Dent Mater. 2018;34:1449-58. https://pubmed.ncbi.nlm.nih.gov/29929845/.

210. Bauer J, Silva e Silva A, Carvalho EM, Carvalho CN, Carvalho RM, Manso AP. A niobophosphate bioactive glass suspension for rewetting dentin: effect on antibacterial activity, $\mathrm{pH}$ and resin-dentin bonding durability. Int $\mathrm{J}$ Adhes Adhes. 2018;84:178-83. https://linkinghub.elsevier.com/retrieve/pii/ S0143749618300824.

211. Carvalho CN, Wang Z, Shen Y, Gavini G, Martinelli JR, Manso $\mathrm{A}$, et al. Comparative analyses of ion release, $\mathrm{pH}$ and multispecies biofilm formation between conventional and bioactive gutta-percha. Int Endod J. 2016;49:1048-56. https://pubmed. ncbi.nlm.nih.gov/26443466/.

212. Balbinot G de S, Leitune VCB, Ogliari FA, Collares FM. Niobium silicate particles as bioactive fillers for composite resins. Dent Mater. 2020;36:1578-85. https://linkinghub.elsevier.com/ retrieve/pii/S0109564120302505.

213. Meneses CCB, Olivi LT, Carvalho CN, Gavini G, Sipert CR. Cytotoxic effect of niobium phosphate glass-based gutta-percha points on periodontal ligament fibroblasts in vitro. J Endod. 2020;46:1297-301. https://linkinghub.elsevier.com/retrieve/pii/ S0099239920304271.

214. Denry IL, Holloway JA, Nakkula RJ, Walters JD. Effect of niobium content on the microstructure and thermal properties of fluorapatite glass-ceramics. J Biomed Mater Res Part B Appl Biomater. 2005;75B:18-24. https://doi.org/10.1002/jbm.b. 30295.

215. Altmann ASP, Collares FM, Balbinot GDS, Leitune VCB Takimi AS, Samuel SMW. Niobium pentoxide phosphate invert glass as a mineralizing agent in an experimental orthodontic adhesive. Angle Orthod. 2017;87:759-65. https://pubmed.ncbi. nlm.nih.gov/28686093/.

216. Balbinot G, de S, Bahlis EA, da C, Visioli F, Leitune VCB, Soares RMD, Collares FM. Polybutylene-adipate-terephthalate and niobium-containing bioactive glasses composites: Development of barrier membranes with adjusted properties for guided bone regeneration. Mater Sci Eng C. 2021;125:112115. https:// linkinghub.elsevier.com/retrieve/pii/S092849312100254X

217. Carvalho CN, Martinelli JR, Bauer J, Haapasalo M, Shen Y, Bradaschia-Correa V, et al. Micropush-out dentine bond strength of a new gutta-percha and niobium phosphate glass composite. Int Endod J. 2015;48:451-9. https://pubmed.ncbi.nlm.nih.gov/ 24923365/.

218. Altmann ASP, Collares FM, Leitune VCB, Arthur RA, Takimi AS, Samuel SMW. In vitro antibacterial and remineralizing effect of adhesive containing triazine and niobium pentoxide phosphate inverted glass. Clin Oral Investig. 2017;21:93-103. https://pubmed.ncbi.nlm.nih.gov/26892472/

219. Lima CJ de, Silva IIC da, Barros LFH de, Graneiro JM, da Silva MHP. Resposta do tecido subcutâneo de camundongos à 
implantação de um novo biovidro à base de óxido de nióbio. Matéria (Rio Janeiro). 2011;16:574-82. http://www.scielo.br/j/ $\mathrm{rmat} / \mathrm{a} / \mathrm{bCrJG47} \mathrm{wmpLhk6PkzQHgmfC} /$ ?lang $=\mathrm{pt} \&$ format $=\mathrm{html}$.

220. Madhavi B, Reddy ASS, Prasad PS, Prasad A, Devi PPK, Kumar $\mathrm{VR}$, et al. The impact of $\mathrm{Nb} 2 \mathrm{O} 5$ on in-vitro bioactivity and antibacterial activity of $\mathrm{CaF} 2-\mathrm{CaO}-\mathrm{B} 2 \mathrm{O} 3-\mathrm{P} 2 \mathrm{O} 5-\mathrm{SrO}$ glass system. Ceram Int. 2021;47:28328-37. https://linkinghub. elsevier.com/retrieve/pii/S0272884221020071.

221. Carvalho EM, Ferreira PVC, Gutiérrez MF, Sampaio RF, Carvalho $\mathrm{CN}$, Menezes AS de, et al. Development and characterization of self-etching adhesives doped with $45 \mathrm{~S} 5$ and niobophosphate bioactive glasses: physicochemical, mechanical, bioactivity and interface properties. Dent Mater. 2021;37:103045 . S010956412100107X. https://linkinghub.elsevier.com/retrieve/pii/

222. Kushwaha M, Pan X, Holloway JA, Denry IL. Differentiation of human mesenchymal stem cells on niobium-doped fluorapatite glass-ceramics. Dent Mater. 2012;28:252-60. https://doi.org/10. 1016/j.dental.2011.10.010.

223. Fernandes GVO, Alves G, Linhares ABR, Prado da Silva MH, Granjeiro JM. Evaluation of cytocompatibility of bioglass-niobium granules with human primary osteoblasts: a multiparametric approach. Key Eng Mater. 2011;493-494:37-42. https://www.scientific.net/KEM.493-494.37.

224. Lopes JH, Magalhães A, Mazali IO, Bertran CA. Effect of niobium oxide on the structure and properties of melt-derived bioactive glasses. J Am Ceram Soc. 2014;97:3843-52. https:// doi.org/10.1111/jace.13222.

225. Grazziotin-Soares R, Dourado L, Gonçalves B, Ardenghi D, Ferreira M, Bauer J, et al. Dentin microhardness and sealer bond strength to root dentin are affected by using bioactive glasses as intracanal medication. Materials (Basel). 2020;13:721. https:// pubmed.ncbi.nlm.nih.gov/32033430/.

226. Balbinot G, de S, Leitune VCB, Ponzoni D, Collares FM. Bone healing with niobium-containing bioactive glass composition in rat femur model: a micro-CT study. Dent Mater. 2019;35:14907. https://doi.org/10.1016/j.dental.2019.07.012.

227. Balbinot G, de S, Collares FM, Herpich TL, Visioli F, Samuel SMW, Leitune VCB. Niobium containing bioactive glasses as remineralizing filler for adhesive resins. Dent Mater. 2020;36:221-8. https://doi.org/10.1016/j.dental.2019.11.014.

228. Sato PS, Watanabe T, Maeda H, Obata A, Kasuga T. Structural analysis of $65 \mathrm{ZnO}-30 \mathrm{P}_{2} \mathrm{O}_{5}-5 \mathrm{Nb}_{2} \mathrm{O}_{5}$ invert glass using X-ray photoelectron spectroscopy. Mater Trans. 2019;60:1707-10. https://www.jstage.jst.go.jp/article/matertrans/60/8/60_ M2019070/_article

229. Samudrala R, Azeem PA, Penugurti V, Manavathi B. In vitro evaluation of niobia added soda lime borosilicate bioactive glasses. J Alloy Compd. 2018;764:1072-8. https://doi.org/10. 1016/j.jallcom.2018.06.069.

230. Lopes JH, Souza LP, Domingues JA, Ferreira FV, Alencar Hausen M, Camilli JA, et al. In vitro and in vivo osteogenic potential of niobium-doped 45S5 bioactive glass: a comparative study. J Biomed Mater Res Part B Appl Biomater. 2020;108:1372-87. https://doi.org/10.1002/jbm.b.34486.

231. Miguez-Pacheco V, de Ligny D, Schmidt J, Detsch R, Boccaccini AR. Development and characterization of niobium-releasing silicate bioactive glasses for tissue engineering applications. J Eur Ceram Soc. 2018;38:871-6. https://doi.org/10.1016/j. jeurceramsoc.2017.07.028.

232. Souza L, Lopes JH, Encarnação D, Mazali IO, Martin RA, Camilli $\mathrm{JA}$, et al. Comprehensive in vitro and in vivo studies of novel meltderived $\mathrm{Nb}$-substituted $45 \mathrm{~S} 5$ bioglass reveal its enhanced bioactive properties for bone healing. Sci Rep. 2018;8:12808. http://www.na ture.com/articles/s41598-018-31114-0.
233. Souza LPL, Lopes JH, Ferreira FV, Martin RA, Bertran CA, Camilli JA. Evaluation of effectiveness of 45S5 bioglass doped with niobium for repairing critical-sized bone defect in in vitro and in vivo models. J Biomed Mater Res Part A. 2020;108:44657. https://onlinelibrary.wiley.com/doi/10.1002/jbm.a.36826.

234. Berzina L, Cimdinš R, Dobelis M, Diktenko O, Vetra J. Bioceramics in the system CaO-Nb2O5-P2O5. In: Andersson ÖH, Happonen RP, Yli-Urpo A, editors. Bioceramics. Elsevier; 1994. p. 151-7. https://linkinghub.elsevier.com/retrieve/pii/ B9780080421445500273.

235. Lee S, Maeda H, Obata A, Ueda K, Narushima T, Kasuga T. Structures and dissolution behaviors of CaO-P 2 O $5-\mathrm{TiO} 2 / \mathrm{Nb}$ 2 O $5(\mathrm{Ca} / \mathrm{P} \geq 1)$ invert glasses. J Non Cryst Solids. 2015;426:35-42. https://linkinghub.elsevier.com/retrieve/pii/ S0022309315300831.

236. Obata A, Takahashi Y, Miyajima T, Ueda K, Narushima T, Kasuga T. Effects of niobium ions released from calcium phosphate invert glasses containing $\mathrm{Nb} 2 \mathrm{O} 5$ on osteoblast-like cell functions. ACS Appl Mater Interfaces. 2012;4:5684-90. https://doi.org/10.1021/am301614a.

237. Sene FF, Martinelli JR, Gomes L. Synthesis and characterization of niobium phosphate glasses containing barium and potassium. J Non Cryst Solids. 2004;348:30-7. https://linkinghub.elsevier. com/retrieve/pii/S0022309304006647.

238. Lim TH, Sargent T, Kusubov N. Kinetics of trace element chromium(III) in the human body. Am J Physiol Integr Comp Physiol. 1983;244:R445-54. https://doi.org/10.1152/ajpregu. 1983.244.4.R445.

239. Di Bona KR, Love S, Rhodes NR, McAdory D, Sinha SH, Kern $\mathrm{N}$, et al. Chromium is not an essential trace element for mammals: effects of a "low-chromium" diet. JBIC J Biol Inorg Chem. 2011;16:381-90. https://doi.org/10.1007/s00775-010-0734-y.

240. Bhattacharya PT, Misra SR, Hussain M. Nutritional aspects of essential trace elements in oral health and disease: an extensive review. Scientifica (Cairo). 2016;2016:1-12. http://www.hindaw i.com/journals/scientifica/2016/5464373/.

241. Krishnamacharyulu N, Jagan Mohini G, Little Flower G, Sahaya Baskaran G, Veeraiah N. An in-vitro bioactive, structural and degradation studies on $\mathrm{B} 2 \mathrm{O} 3-\mathrm{SiO} 2-\mathrm{P} 2 \mathrm{O} 5-\mathrm{Na} 2 \mathrm{O}-\mathrm{CaO}$ glass system incorporated with chromium ions. Mater Today Proc. 2018;5:26280-9. https://doi.org/10.1016/j.matpr.2018.08.078.

242. Mendel RR. Cell biology of molybdenum. BioFactors. 2009;35:429-34. https://doi.org/10.1002/biof.55.

243. Mendel RR. Molybdenum: biological activity and metabolism. Dalt Trans. 2005;21:3404 http://xlink.rsc.org/?DOI=b505527j.

244. Sardesai VM. MOLYBDENUM: an essential trace element in human nutrition. Nutr Clin Pr. 1993;8:277-81. https://doi.org/10. 1177/0115426593008006277.

245. Odularu AT, Ajibade PA, Mbese JZ. Impact of molybdenum compounds as anticancer agents. Bioinorg Chem Appl. 2019;2019:1-9. https://www.hindawi.com/journals/bca/2019/ 6416198/

246. Zoroddu MA, Aaseth J, Crisponi G, Medici S, Peana M, Nurchi VM. The essential metals for humans: a brief overview. J Inorg Biochem. 2019;195:120-9. https://linkinghub.elsevier.com/ retrieve/pii/S0162013418306846

247. Ribeiro AM, Flores-Sahagun THS, Paredes RC. A perspective on molybdenum biocompatibility and antimicrobial activity for applications in implants. J Mater Sci. 2016;51:2806-16. https:// doi.org/10.1007/s10853-015-9664-y.

248. Kirakci K, Zelenka J, Rumlová M, Cvacka J, Ruml T, Lang K. Cationic octahedral molybdenum cluster complexes functionalized with mitochondria-targeting ligands: photodynamic anticancer and antibacterial activities. Biomater Sci. 2019;7:1386-92. http://xlink.rsc.org/?DOI=C8BM01564C. 
249. Tian X, Sun Y, Fan S, Boudreau MD, Chen C, Ge C, et al. Photogenerated charge carriers in molybdenum disulfide quantum dots with enhanced antibacterial activity. ACS Appl Mater Interfaces. 2019;11:4858-66. https://doi.org/10.1021/acsami. 8 b19958.

250. Mukheem A, Shahabuddin S, Akbar N, Anwar A, Sarih NM, Sudesh K, et al. Fabrication of biopolymer polyhydroxyalkanoate/chitosan and 2D molybdenum disulfide-doped scaffolds for antibacterial and biomedical applications. Appl Microbiol Biotechnol. 2020;104:3121-31. https://doi.org/10.1007/s00253020-10416-2.

251. Tekin HO, Abouhaswa AS, Kilicoglu O, Issa SAM, Akkurt I, Rammah YS. Fabrication, physical characteristic, and gammaphoton attenuation parameters of newly developed molybdenum reinforced bismuth borate glasses. Phys Scr. 2020;95:115703 https://doi.org/10.1088/1402-4896/abbf6e.

252. Pramanik M, Bhaumik A. Self-assembled hybrid molybdenum phosphonate porous nanomaterials and their catalytic activity for the synthesis of benzimidazoles. ChemCatChem. 2014;6:257786. https://doi.org/10.1002/cctc.201402291.

253. Vedeanu NS, Magdas DA. The influence of some transition metal ions in lead- and calcium-phosphate glasses. J Alloys Compd. 2012;534:93-6. https://linkinghub.elsevier.com/retrieve/ pii/S0925838812007438.

254. Niu W, Guo Y, Xue Y, Chen M, Wang M, Cheng W, et al. Monodisperse branched molybdenum-based bioactive nanoparticles significantly promote osteogenic differentiation of adipose-derived stem cells. Part Part Syst Charact. 2019;36:1900105 https://doi.org/10.1002/ppsc.201900105.

255. Ponta O, Ciceo-Lucacel R, Vulpoi A, Radu T, Simon S. Molybdenum effect on the structure of $\mathrm{SiO} 2-\mathrm{CaO}-\mathrm{P} 2 \mathrm{O} 5$ bioactive xerogels and on their interface processes with simulated biofluids. J Biomed Mater Res Part A. 2014;102:3177-85. https://doi.org/10.1002/jbm.a.34989.

256. Dang W, Wang X, Li J, Deng C, Liu Y, Yao Q, et al. 3D printing of Mo-containing scaffolds with activated anabolic responses and bi-lineage bioactivities. Theranostics. 2018;8:4372-92. http://www.thno.org/v08p4372.htm.

257. Lucacel RC, Ponta O, Licarete E, Radu T, Simon V. Synthesis, structure, bioactivity and biocompatibility of melt-derived P2O5CaO-B2O3-K2O-MoO3 glasses. J Non Cryst Solids. 2016;439:67-73. https://linkinghub.elsevier.com/retrieve/pii/ S0022309316300424.

258. El-Meliegy E, Farag MM, Knowles JC. Dissolution and drug release profiles of phosphate glasses doped with high valency oxides. J Mater Sci Mater Med. 2016;27:108 https://doi.org/10. 1007/s10856-016-5711-8.

259. Barrio DA, Etcheverry SB. Vanadium and bone development: putative signaling pathways. Can J Physiol Pharm. 2006;84:67786. https://pubmed.ncbi.nlm.nih.gov/16998531/.

260. Rehder D. Interrelations between essential metal ions and human diseases. In: Sigel A, Sigel H, Sigel RKO, editors. Metal ions in life sciences. Vol. 13. Dordrecht: Springer Netherlands; 2013. p. 139-69. https://doi.org/10.1007/978-94-007-7500-8.

261. Pal RP, Mani V, Tripathi D, Kumar R, Kewalramani NJ. Influence of feeding inorganic vanadium on growth performance, endocrine variables and biomarkers of bone health in crossbred calves. Biol Trace Elem Res. 2018;182:248-56. https://doi.org/ 10.1007/s12011-017-1095-y.

262. Kilcup N, Gaynard S, Werner-Zwanziger U, Tonkopi E, Hayes J, Boyd D. Stimulation of apoptotic pathways in liver cancer cells: an alternative perspective on the biocompatibility and the utility of biomedical glasses. J Biomater Appl. 2016;30:1445-59. https://pubmed.ncbi.nlm.nih.gov/26675751/.

263. Ori G, Montorsi M, Pedone A, Siligardi C. Insight into the structure of vanadium containing glasses: a molecular dynamics study. J Non Cryst Solids. 2011;357:2571-9. https://linkinghub. elsevier.com/retrieve/pii/S0022309311001098.

264. Kumari CV, Kumar VR, Sobhanachalam P, Rao PV, Baskaran GS, Veeraiah N. In vitro degradation studies on bioactive calcium fluoroborophosphate glasses mixed with some modifier oxides-influence of therapeutically active vanadium ions. Mater Chem Phys. 2018;205:376-90. https://linkinghub.elsevier.com/ retrieve/pii/S0254058417309082.

265. Wang YM, Wu SY, Jiang SJ, Luo YJ, Zhu QS, Han M. Investigations of defect structures for $\mathrm{V} 4+$ in CBPB glasses with distinct V2O5 contents. J Non Cryst Solids. 2021;566:120879 https://linkinghub.elsevier.com/retrieve/pii/S0022309321002386

266. Deliormanli AM. In vitro assessment of degradation and mineralisation of $\mathrm{V} 2 \mathrm{O} 5$ substituted borate bioactive glass scaffolds. Mater Technol. 2014;29:358-65. https://doi.org/10. 1179/1753555714Y.0000000167.

267. Marzouk MA, ElBatal FH, Ghoneim NA. In vitro bioactivity behavior of modified multicomponent borate glasses containing dopants of $\mathrm{Ag} 2 \mathrm{O}, \mathrm{CuO}, \mathrm{CeO} 2$ or V2O5. Appl Phys A. 2018;124:110 https://doi.org/10.1007/s00339-017-1526-9.

268. Deliormanli AM, Seda Vatansever H, Yesil H, Özdal-Kurt F. In vivo evaluation of cerium, gallium and vanadium-doped boratebased bioactive glass scaffolds using rat subcutaneous implantation model. Ceram Int. 2016;42:11574-83. https://doi.org/10. 1016/j.ceramint.2016.04.033.

269. Deliormanli AM, Oguzlar S, Ertekin K. Photoluminescence and decay characteristics of cerium, gallium and vanadium - containing borate-based bioactive glass powders for bioimaging applications. Ceram Int. 2021;47:3797-807. https://linkinghub. elsevier.com/retrieve/pii/S0272884220329552.

270. Deliormanli AM, Al-Buriahi MS, Somaily HH, Tekin HO. Correction to: 13-93B3 Bioactive glasses containing $\mathrm{Ce} 3+, \mathrm{Ga} 3$ + and V5+: dose rate and gamma radiation characteristic for medical purposes. Appl Phys A. 2021;127:245 https://doi.org/10. 1007/s00339-021-04407-x.

271. Li J, Li X, Li J, Pu X, Wang J, Huang Z, et al. Effects of incorporated vanadium and its chemical states on morphology and mesostructure of mesoporous bioactive glass particles. Microporous Mesoporous Mater. 2021;319:111061 https:// linkinghub.elsevier.com/retrieve/pii/S1387181121001876.

272. Beattie JH, Avenell A. Trace element nutrition and bone metabolism. Nutr Res Rev. 1992;5:167-88. https://www.cambridge.org/ core/product/identifier/S0954422492000143/type/journal_article.

273. Rau JV, De Stefanis A, Barbaro K, Fosca M, Yankova VG, Matassa R, et al. Adipogenic, chondrogenic, osteogenic, and antimicrobial features of glass ceramic material supplemented with manganese. J Non Cryst Solids. 2021;559:120709 https:// linkinghub.elsevier.com/retrieve/pii/S0022309321000685

274. Tseng CF, Fei YC, Chou YJ. Investigation of in vitro bioactivity and antibacterial activity of manganese-doped spray pyrolyzed bioactive glasses. J Non Cryst Solids. 2020;549:120336 https:// linkinghub.elsevier.com/retrieve/pii/S0022309320304488

275. Tripathi H, Pandey GC, Dubey A, Shaw SK, Prasad NK, Singh SP, et al. Superparamagnetic manganese ferrite and strontium bioactive glass nanocomposites: enhanced biocompatibility and antimicrobial properties for hyperthermia application. Adv Eng Mater. 2021;23:2000275 https://doi.org/10.1002/adem. 202000275.

276. Liu Y, Lin R, Ma L, Zhuang H, Feng C, Chang J, et al. Mesoporous bioactive glass for synergistic therapy of tumor and regeneration of bone tissue. Appl Mater Today. 2020;19:100578 https://doi.org/10.1016/j.apmt.2020.100578.

277. Sarin N, Singh KJ, Kaur R, Singh J. Manganese and zinc doped $\mathrm{CaO}-\mathrm{SiO} 2$-P 2 O 5 bioceramics for recovery from bone defects. Integr Ferroelectr. 2020;204:142-9. https://doi.org/10.1080/ 10584587.2019.1674973. 
278. Barrioni BR, Norris E, Li S, Naruphontjirakul P, Jones JR, Pereira M, de M. Osteogenic potential of sol-gel bioactive glasses containing manganese. J Mater Sci Mater Med. 2019;30:86 https://doi.org/10.1007/s10856-019-6288-9.

279. Ferreira M, Brito A, Brazete D, Pereira I, Carrilho E, Abrantes A, et al. Doping $\beta$-TCP as a strategy for enhancing the regenerative potential of composite $\beta$-TCP-alkali-free bioactive glass bone grafts. Experimental study in rats. Materials (Basel). 2018;12:4 https://pubmed.ncbi.nlm.nih.gov/30577440/.

280. Vadera N, Ashokan A, Gowd GS, Sajesh KM, Chauhan RP, Jayakumar R, et al. Manganese doped nano-bioactive glass for magnetic resonance imaging. Mater Lett. 2015;160:335-8. https://doi.org/10.1016/j.matlet.2015.07.158.

281. Srivastava AK, Pyare R, Singh SP. In vitro bioactivity and physical-mechanical properties of $\mathrm{MnO} 2$ substituted 45S5 bioactive glasses and glass-ceramics. J Biomater Tissue Eng. 2012;2:249-58. http://openurl.ingenta.com/content/xref? genre $=$ article $\& i s s n=2157-9083 \&$ volume $=2 \&$ issue $=3 \&$ spage $=$ 249.

282. Miola M, Brovarone CV, Maina G, Rossi F, Bergandi L, Ghigo $\mathrm{D}$, et al. In vitro study of manganese-doped bioactive glasses for bone regeneration. Mater Sci Eng C. 2014;38:107-18. https:// doi.org/10.1016/j.msec.2014.01.045.

283. Cañaveral S, Morales D, Vargas AF. Synthesis and characterization of a $58 \mathrm{~S}$ bioglass modified with manganese by a sol-gel route. Mater Lett. 2019;255:126575. https://linkinghub.elsevier. com/retrieve/pii/S0167577X19311966.

284. Barrioni BR, Oliveira AC, de Fátima Leite M, de Magalhães Pereira M. Sol-gel-derived manganese-releasing bioactive glass as a therapeutic approach for bone tissue engineering. J Mater Sci. 2017;52:8904-27. https://doi.org/10.1007/s10853-017-0944-6.

285. Nawaz Q, Rehman MAU, Burkovski A, Schmidt J, Beltrán AM, Shahid A, et al. Synthesis and characterization of manganese containing mesoporous bioactive glass nanoparticles for biomedical applications. J Mater Sci Mater Med. 2018;29:64 https:// doi.org/10.1007/s10856-018-6070-4.

286. Westhauser F, Wilkesmann S, Nawaz Q, Hohenbild F, Rehder F, Saur M, et al. Effect of manganese, zinc, and copper on the biological and osteogenic properties of mesoporous bioactive glass nanoparticles. J Biomed Mater Res Part A. 2021;109:145767. https://doi.org/10.1002/jbm.a.37136.

287. Westhauser F, Wilkesmann S, Nawaz Q, Schmitz SI, Moghaddam A, Boccaccini AR. Osteogenic properties of manganesedoped mesoporous bioactive glass nanoparticles. J Biomed Mater Res Part A. 2020;108:1806-15. https://doi.org/10.1002/ jbm.a.36945.

288. Bragiel P, Ficek P, Prochwicz W, Radkowska I, Veeraiah N. Are the phosphorus-rich $\mathrm{Na} 2 \mathrm{O}-\mathrm{CaO}-\mathrm{B} 2 \mathrm{O} 3-\mathrm{SiO} 2-\mathrm{P} 2 \mathrm{O} 5$ glasses bioactive and what is an influence of doping with manganese oxide? Mater Sci. 2017;35:760-6. https://doi.org/10.1515/msp2017-0093.

289. Aina V, Cerrato G, Martra G, Bergandi L, Costamagna C, Ghigo $\mathrm{D}$, et al. Gold-containing bioactive glasses: a solid-state synthesis to produce alternative biomaterials for bone implantations. J R Soc Interface. 2013;10:20121040 https://doi.org/10.1098/rsif. 2012.1040.

290. Lusvardi G, Malavasi G, Aina V, Bertinetti L, Cerrato G, Magnacca $\mathrm{G}$, et al. Bioactive glasses containing $\mathrm{Au}$ nanoparticles. Effect of calcination temperature on structure, morphology, and surface properties. Langmuir. 2010;26:10303-14. https://doi.org/10.1021/la100472p.

291. Mârza SM, Magyari K, Bogdan S, Moldovan M, Pe?tean C, Nagy A, et al. The impact of composites with silicate-based glasses and gold nanoparticles on skin wound regeneration. Molecules. 2021;26:620. https://www.mdpi.com/1420-3049/26/ 3/620/htm.
292. Yin C, Zhao Q, Li W, Zhao Z, Wang J, Deng T, et al. Biomimetic anti-inflammatory nano-capsule serves as a cytokine blocker and M2 polarization inducer for bone tissue repair. Acta Biomater. 2020;102:416-26. https://linkinghub.elsevier.com/ retrieve/pii/S1742706119307664.

293. Wang CK, Chen SH, Li WY, Lai CH, Chen WC. Bioactive glass shell growth of a Si-Na-Ca-P layer on gold nanoparticles functionalized with mercaptopropyltrimethyloxysilane-silicate- tetraethylothosilicate. Surf Rev Lett. 2009;16:37-42. https://doi.org/ 10.1142/S0218625X09012263.

294. Wang G, Wu X, Cen D, He H, Fu Y, Ren Z, et al. A bifunctional scaffold for tissue regeneration and photothermal therapy. $\mathrm{J}$ Biomed Nanotechnol. 2018;14:698-706. https://doi.org/10.1166/ jbn.2018.2548.

295. Simon S, Ciceo-Lucacel R, Radu T, Baia L, Ponta O, Iepure A, et al. Gold nanoparticles developed in sol-gel derived apatitebioactive glass composites. J Mater Sci Mater Med. 2012;231193-201. https://doi.org/10.1007/s10856-012-4590-x.

296. Yao L, Wang X, Weng W, Fu Y, Cheng K. Bioactive nanocomposite coatings under visible light illumination promoted surface-mediated gene delivery. Biomater Sci. 2020;8:3685-96. https://pubs.rsc.org/en/content/articlehtml/2020/bm/ d0bm00123f.

297. Catauro M, Papale F, Caputo P, Donnarumma G. Chemical, biological, and antibacterial characterization of silica glass containing silver and gold nanoparticles. Int J Appl Ceram Technol. 2017;14:108-16. https://doi.org/10.1111/ijac.12643.

298. Aina V, Ghigo D, Marchis T, Cerrato G, Laurenti E, Morterra C, et al. Novel bio-conjugate materials: soybean peroxidase immobilized on bioactive glasses containing Au nanoparticles. J Mater Chem. 2011;21:10970-81. https://pubs.rsc.org/en/ content/articlehtml/2011/jm/c1jm10442j.

299. Regos AN, Ardelean I. Preparation, structure and bioactivity of $\mathrm{xAu} 2 \mathrm{O} 3 \cdot(100-\mathrm{x})[\mathrm{P} 2 \mathrm{O} 5 \cdot \mathrm{CaO}]$ glass system. J Mol Struct. 2011;1006:312-7.

300. Aina V, Marchis T, Laurenti E, Diana E, Lusvardi G, Malavasi $\mathrm{G}$, et al. Functionalization of sol gel bioactive glasses carrying Au nanoparticles: selective Au affinity for amino and thiol ligand groups. Langmuir. 2010;26:18600-5. https://doi.org/10.1021/la 1036647.

301. Jayalekshmi AC, Sharma CP. Gold nanoparticle incorporated polymer/bioactive glass composite for controlled drug delivery application. Colloids Surfaces B Biointerfaces. 2015;126:280-7. https://linkinghub.elsevier.com/retrieve/pii/ S0927776514006985.

302. Mârza S, Magyari K, Bogdan S, Moldovan M, Pestean C, Nagy A, et al. Skin wound regeneration with bioactive glass-gold nanoparticles ointment. Biomed Mater. 2019;14:025011. https:// pubmed.ncbi.nlm.nih.gov/30630137/.

303. Magyari K, Tóth ZR, Pap Z, Licarete E, Vodnar DC, Todea M, et al. Insights into the effect of gold nanospheres, nanotriangles and spherical nanocages on the structural, morphological and biological properties of bioactive glasses. J Non Cryst Solids. 2019;522:119552. https://linkinghub.elsevier.com/retrieve/pii/ S0022309319304235

304. Dreanca A, Muresan-Pop M, Taulescu M, Tóth ZR, Bogdan S, Pestean $\mathrm{C}$, et al. Bioactive glass-biopolymers-gold nanoparticle based composites for tissue engineering applications. Mater Sci Eng C. 2021;123:112006 https://linkinghub.elsevier.com/ retrieve/pii/S0928493121001454

305. Magyari K, Nagy-Simon T, Vulpoi A, Popescu RA, Licarete E, Stefan R, et al. Novel bioactive glass-AuNP composites for biomedical applications. Mater Sci Eng C. 2017;76:752-9. https://doi.org/10.1016/j.msec.2017.03.138.

306. Grandi S, Cassinelli V, Bini M, Saino E, Mustarelli P, Arciola $\mathrm{CR}$, et al. Bone reconstruction: $\mathrm{Au}$ nanocomposite bioglasses 
with antibacterial properties. Int J Artif Organs. 2011;34:920-8. https://doi.org/10.5301/ijao.5000059.

307. Tekin HO, Kavaz E, Altunsoy EE, Kilicoglu O, Agar O, Erguzel TT, et al. An extensive investigation on gamma-ray and neutron attenuation parameters of cobalt oxide and nickel oxide substituted bioactive glasses. Ceram Int. 2019;45:9934-49. https:// linkinghub.elsevier.com/retrieve/pii/S0272884219303335

308. Floroian L, Florescu M, Munteanu D, Badea M, Popescu-Pelin $\mathrm{G}$, Ristoscu C, et al. A new concept of stainless steel medical implant based upon composite nanostructures coating. Dig $\mathrm{J}$ Nanomater Biostructures. 2014;9:1555-68. https://chalcogen.ro/ 1555_Floroian.pdf

309. Smith JM, Martin RA, Cuello GJ, Newport RJ. Structural characterisation of hypoxia-mimicking bioactive glasses. J Mater Chem B. 2013;1:1296. http://xlink.rsc.org/?DOI=c3tb00408b.

310. Kumari CV, Gandhi Y, Sobhanachalam P, Reddy ASS, Venkatramaiah N, Rao PV, et al. Bioactive behaviour of NiO substituted CaF2-CaO-B2O3-BaO-P2O5 glasses by means of spectroscopic studies. Opt Mater (Amst). 2019;97:109394 https://linkinghub.elsevier.com/retrieve/pii/S0925346719306147

311. Elnahrawy A, Elokr MM, Metawe F, Osman BA, el kader A. Characteristics and magnetic properties of $((80-\mathrm{x})$ P2O5: 20 $\mathrm{SiO} 2: \mathrm{X} \mathrm{A12O3)}$ and doped with $\mathrm{Ni2O} 3$ prepared by sol gel method. J Ovonic Res. 2016;12:253-9. https://www.researchga te.net/publication/309427094_Characteristics_and_magnetic_ properties_of_80-x_P2O5_20_SiO2_X_A12O3_and_doped_w ith_Ni2O3_prepared_by_sol_gel_method.

312. Boukhris I, Alalawi A, Al-Buriahi MS, Kebaili I, Sayyed MI. Radiation attenuation properties of bioactive glasses doped with NiO. Ceram Int. 2020;46:19880-9. https://linkinghub.elsevier. com/retrieve/pii/S0272884220313328

313. Vyas VK, Kumar AS, Ali A, Prasad S, Srivastava P, Mallick SP, et al. Assessment of nickel oxide substituted bioactive glassceramic on in vitro bioactivity and mechanical properties. Boletín la Soc Española Cerámica y Vidr. 2016;55:228-38. https://doi.org/10.1016/j.bsecv.2016.09.005.

314. Vyas VK, Sampath Kumar A, Singh SP, Pyare R. Effect of nickel oxide substitution on bioactivity and mechanical properties of bioactive glass. Bull Mater Sci. 2016;39:1355-61. https:// doi.org/10.1007/s12034-016-1242-7.

315. Vyas VK, Kumar AS, Singh SP, Pyare R. Destructive and nondestructive behavior of nickel oxide doped bioactive glass and glass-ceramic. J Aust Ceram Soc. 2017;53:939-51. https://doi. org/10.1007/s41779-017-0110-2.

316. Adam V, Hanustiak P, Krizkova S, Beklova M, Zehnalek J, Trnkova L, et al. Palladium biosensor. Electroanalysis. 2007;19:1909-14. https://doi.org/10.1002/elan.200703953.

317. Pranczk J, Jacewicz D, Wyrzykowski D, Chmurzynski L. Platinum (II) and Palladium(II) complex compounds as anti-cancer drugs. Methods of cytotoxicity determination. Curr Pharm Anal. 2014;10:2-9. http://www.eurekaselect.com/openurl/content.php? genre $=$ article \&issn $=1573-4129 \&$ volume $=10 \&$ issue $=1 \&$ spage $=2$.

318. Ulukaya E, Ari F, Dimas K, Ikitimur EI, Guney E, Yilmaz VT. Anti-cancer activity of a novel palladium(II) complex on human breast cancer cells in vitro and in vivo. Eur $\mathrm{J}$ Med Chem. 2011;46:4957-63. https://linkinghub.elsevier.com/retrieve/pii/ S022352341100568X.

319. Wu W, Liu ZW, Hua JJ, Lin CC, Zeng Y, Ding F. Preparation of palladium-containing mesoporous bioactive glass catalyst and evaluation of its catalytic effect on oxidation of benzyl alcohol. Mater Res Innov. 2013;17:53-7. https://doi.org/10.1179/ 1432891713Z.000000000180.

320. Medkov MA, Grishchenko DN, Kuryavyi VG, Slobodyuk AB. Tungsten-containing bioactive radiocontrast glass: production and properties. Glas Ceram. 2018;75:322-6. https://doi.org/10. 1007/s10717-018-0079-5.
321. Deliormanli AM, Ensoylu M, Issa SAM, Elshami W, Al-Baradi AM, Al-Buriahi MS, et al. WS2/bioactive glass composites: fabrication, structural, mechanical and radiation attenuation properties. Ceram Int. 2021;47:29739-47. https://linkinghub. elsevier.com/retrieve/pii/S0272884221021878.

322. Uosif MAM, Mostafa AMA, Issa SAM, Tekin HO, Alrowaili ZA, Kilicoglu O. Structural, mechanical and radiation shielding properties of newly developed tungsten lithium borate glasses: an experimental study. J Non Cryst Solids. 2020;532:119882. https://linkinghub.elsevier.com/retrieve/pii/ S0022309319307525.

323. Berend K, van Hulsteijn LH, Gans ROB. Chloride: the queen of electrolytes? Eur J Intern Med. 2012;23:203-11. https:// linkinghub.elsevier.com/retrieve/pii/S0953620511002779.

324. Chungong LF, Swansbury LA, Mountjoy G, Hannon AC, Lee AF, Martin RA. Atomic structure of chlorine containing calcium silicate glasses by neutron diffraction and $29 \mathrm{Si}$ solid-state NMR. Int J Appl Glas Sci. 2017;8:383-90. https://doi.org/10.1111/ijag.12280.

325. Swansbury LA, Mountjoy G, Chen X, Karpukhina N, Hill R. Modeling the onset of phase separation in $\mathrm{CaO}-\mathrm{SiO} 2-\mathrm{CaCl} 2$ chlorine-containing silicate glasses. J Phys Chem B. 2017;121:5647-53. https://doi.org/10.1021/acs.jpcb.7b02986.

326. Pedone A, Chen X, Hill RG, Karpukhina N. Molecular dynamics investigation of halide-containing phospho-silicate bioactive glasses. J Phys Chem B. 2018;122:2940-8. https://doi.org/10. 1021/acs.jpcb.8b00547.

327. Chen X, Karpukhina N, Brauer DS, Hill RG. Novel highly degradable chloride containing bioactive glasses. Biomed Glas. 2015;1:108-18. https://doi.org/10.1515/bglass-2015-0010/html.

328. Chen X, Hill R, Karpukhina N. Chlorapatite glass-ceramics. Int J Appl Glas Sci. 2014;5:207-16. https://doi.org/10.1111/ijag.12082.

329. Chen X, Chen X, Pedone A, Apperley D, Hill RG, Karpukhina N. New insight into mixing fluoride and chloride in bioactive silicate glasses. Sci Rep. 2018;8:1316 http://www.nature.com/a rticles/s41598-018-19544-2.

330. Abraham G, Flechas J, Hakala J. Orthoiodosupplementation: iodine sufficiency of the whole human body. 2007. https://hea 1thfully.files.wordpress.com/2017/03/iod02.pdf. Accessed 20 Aug 2021.

331. Ottomeyer M, Mohammadkah A, Day D, Westenberg D. Broadspectrum antibacterial characteristics of four novel borate-based bioactive glasses. Adv Microbiol. 2016;6:776-87. https://doi. org/10.4236/aim.2016.610076.

332. Gupta B, Papke JB, Mohammadkhah A, Day DE, Harkins AB. Effects of chemically doped bioactive borate glass on neuron regrowth and regeneration. Ann Biomed Eng. 2016;44:3468-77. https://doi.org/10.1007/s10439-016-1689-0.

333. Li L, Ruan T, Lyu Y, Wu B. Advances in effect of germanium or germanium compounds on animals-a review. J Biosci Med. 2017;5:56-73. http://www.scirp.org/journal/PaperInformation. aspx?PaperID $=77890$.

334. Goodman S. Therapeutic effects of organic germanium. Med Hypotheses. 1988;26:207-15. https://linkinghub.elsevier.com/ retrieve/pii/0306987788901016.

335. Khader BA, Rodriguez $\mathrm{O}$, Towler $\mathrm{M}$. Incorporating germanium oxide into the glass phase of novel zinc/magnesium-based GPCs designed for bone void filling: evaluating their physical and mechanical properties. J Funct Biomater. 2018;9:47. http://www. mdpi.com/2079-4983/9/3/47.

336. Mokhtari S, Krull EA, Sanders LM, Coughlan A, Mellott NP, Gong $\mathrm{Y}$, et al. Investigating the effect of germanium on the structure of $\mathrm{SiO} 2-\mathrm{ZnO}-\mathrm{CaO}-\mathrm{SrO}-\mathrm{P} 2 \mathrm{O} 5$ glasses and the subsequent influence on glass polyalkenoate cement formation, solubility and bioactivity. Mater Sci Eng C. 2019;103:109843. https://linkinghub.elsevier.com/retrieve/pii/S09284931173 48956. 
337. Saddeek YB, Issa SAM, Guclu EEA, Kilicoglu O, Susoy G, Tekin HO. Alkaline phosphate glasses and synergistic impact of germanium oxide $(\mathrm{GeO} 2)$ additive: mechanical and nuclear radiation shielding behaviors. Ceram Int. 2020;46:16781-97. https://linkinghub.elsevier.com/retrieve/pii/ S0272884220309020.

338. Wang R, Li H, Sun H. Bismuth: environmental pollution and health effects. In: Nriagu J, editor. Encyclopedia of environmental health. Elsevier; 2019. p. 415-23. https://linkinghub. elsevier.com/retrieve/pii/B9780124095489118706.

339. Thomas F, Bialek B, Hensel R. Medical use of bismuth: the two sides of the coin. J Clin Toxicol. 2011;3:4. https://www. omicsonline.org/medical-use-of-bismuth-the-two-sides-of-thecoin-2161-0495.S3-004.php?aid=5343.

340. Lin DJ, Tsai MT, Shieh TM, Huang HL, Hsu JT, Ko YC, et al. In vitro antibacterial activity and cytocompatibility of bismuth doped micro-arc oxidized titanium. J Biomater Appl. 2013;27:553-63. https://doi.org/10.1177/0885328211414942.

341. Slikkerveer A, Wolff FA. Pharmacokinetics and toxicity of bismuth compounds. Med Toxicol Advers Drug Exp. 1989;4:30323. https://doi.org/10.1007/BF03259915.

342. Boukhris I, Kebaili I, Al-Buriahi MS, Tonguc B, AlShammari MM, Sayyed MI. Effect of bismuth oxide on the optical features and gamma shielding efficiency of lithium zinc borate glasses. Ceram Int. 2020;46:22883-8. https://linkinghub.elsevier.com/ retrieve/pii/S0272884220317089.

343. Pazarçeviren AE, Evis Z, Keskin D, Tezcaner A. Resorbable PCEC/gelatin-bismuth doped bioglass-graphene oxide bilayer membranes for guided bone regeneration. Biomed Mater. 2019;14:035018. https://doi.org/10.1088/1748-605X/ab007b.

344. Khatua C, Bodhak S, Kundu B, Balla VK. In vitro bioactivity and bone mineralization of bismuth ferrite reinforced bioactive glass composites. Materialia. 2018;4:361-6. https://doi.org/10. 1016/j.mtla.2018.10.014.

345. Wang L, Long NJ, Li L, Lu Y, Li M, Cao J, et al. Multi-functional bismuth-doped bioglasses: combining bioactivity and photothermal response for bone tumor treatment and tissue repair. Light Sci Appl. 2018;7:1 https://doi.org/10.1038/s41377-018-0007-z.

346. Prasad SS, Ratha I, Adarsh T, Anand A, Sinha PK, Diwan P, et al. In vitro bioactivity and antibacterial properties of bismuth oxide modified bioactive glasses. J Mater Res. 2018;33:178-90. https://doi.org/10.1557/jmr.2017.442.

347. Heid S, Stoessel PR, Tauböck TT, Stark WJ, Zehnder M, Mohn D. Incorporation of particulate bioactive glasses into a dental root canal sealer. Biomed Glas. 2016;2:29-37. https://doi.org/10. 1515/bglass-2016-0004/html.

348. Esmail SAA, Shamsi M, Chen T, Al-asbahy WM. Design, synthesis and characterization of tin-based cancer chemotherapy drug entity: In vitro DNA binding, cleavage, induction of cancer cell apoptosis by triggering DNA damage-mediated p53 phosphorylation and molecular docking. Appl Organomet Chem. 2019;33:e4651 https://doi.org/10.1002/aoc.4651.

349. Meng X, You L, Li S, Sun Q, Luo X, He H, et al. An ICTbased fluorescence enhancement probe for detection of Sn $2+$ in cancer cells. RSC Adv. 2020;10:37735-42. http://xlink.rsc. org/?DOI=D0RA07330J.

350. Alfadhli S, Kumar A, Sayyed MI, Jain A, Laariedh F, Mahmoud $\mathrm{KA}$, et al. Gamma ray interaction studies of the $\mathrm{PbCl} 2-\mathrm{SnCl} 2$ $\mathrm{P} 2 \mathrm{O} 5$ bioactive glass system for applications in nuclear medicine. J Aust Ceram Soc. 2021;57:635-42. https://doi.org/10. 1007/s41779-021-00564-7.

351. Akin SRK, Dolekcekic E, Webster TJ. Effect of nitrogen on the antibacterial behavior of oxynitride glasses. Ceram Int. 2021;47:18213-7. https://linkinghub.elsevier.com/retrieve/pii/ S0272884221008270.
352. Hanifi AR, Crowley CM, Pomeroy MJ, Hampshire S. Bioactivity potential of calcium alumino-silicate glasses and glass-ceramics containing nitrogen and fluorine. J Mater Sci. 2014;49:4590-4. https://doi.org/10.1007/s10853-014-8159-6.

353. Al-Hadeethi Y, Al-Buriahi MS, Sayyed MI. Bioactive glasses and the impact of Si3N4 doping on the photon attenuation up to radiotherapy energies. Ceram Int. 2020;46:5306-14. https:// linkinghub.elsevier.com/retrieve/pii/S0272884219331554.

354. Wójcik NA, Jonson B, Möncke D, Palles D, Kamitsos EI, Ghassemali $\mathrm{E}$, et al. Influence of synthesis conditions on glass formation, structure and thermal properties in the Na2O-CaO-P2O5 system doped with Si3N4 and Mg. J Non Cryst Solids. 2018;494:66-77. https://doi.org/10.1016/j.jnoncrysol.2018.04.055.

355. Bachar A, Mercier C, Tricoteaux A, Leriche A, Follet C, Saadi $\mathrm{M}$, et al. Effects of addition of nitrogen on bioglass properties and structure. J Non Cryst Solids. 2012;358:693-701. https://doi. org/10.1016/j.jnoncrysol.2011.11.036.

356. Bachar A, Mercier C, Tricoteaux A, Leriche A, Follet-Houttemane C, Saadi M, et al. Effects of nitrogen on properties of oxyfluoronitride bioglasses. Process Biochem. 2013;48:89-95. https://linkinghub.elsevier.com/retrieve/pii/ S1359511312002292.

357. Mabrouk A, Bachar A, Atbir A, Follet C, Mercier C, Tricoteaux A, et al. Mechanical properties, structure, bioactivity and cytotoxicity of bioactive Na-Ca-Si-P-O-(N) glasses. J Mech Behav Biomed Mater. 2018;86:284-93. https://doi.org/10.1016/j. jmbbm.2018.06.023.

358. Marin E, Adachi T, Boschetto F, Zanocco M, Rondinella A, Zhu $\mathrm{W}$, et al. Biological response of human osteosarcoma cells to Si3N4-doped Bioglasses. Mater Des. 2018;159:79-89. https:// doi.org/10.1016/j.matdes.2018.08.020.

359. Schroeder HA, Buckman J, Balassa JJ. Abnormal trace elements in man: tellurium. J Chronic Dis. 1967;20:147-61. https:// linkinghub.elsevier.com/retrieve/pii/0021968167900495.

360. Ma MG, Zhu JF, Sun RC, Chen F, Zhu YJ. Synthesis and characterization of the tellurium/calcium silicate nanocomposite. Mater Lett. 2011;65:424-6. https://doi.org/10.1016/j.matlet. 2010.10.083.

361. El-Damrawi G, Doweidar H, Kamal H. Characterization of new categories of bioactive based tellurite and silicate glasses. Silicon. 2017;9:503-9. https://doi.org/10.1007/s12633-014-9248-5.

362. Tekin HO, Kassab LRP, Kilicoglu O, Magalhães ES, Issa SAM, da Silva Mattos GR. Newly developed tellurium oxide glasses for nuclear shielding applications: an extended investigation. J Non Cryst Solids. 2020;528:119763 https://doi.org/10.1016/j. jnoncrysol.2019.119763.

363. Rammah YS. Evaluation of radiation shielding ability of borotellurite glasses: TeO2-B2O3-SrCl2-LiF-Bi2O3. Appl Phys A. 2019;125:857 https://doi.org/10.1007/s00339-019-3154-z.

364. Wang H, Chai L, Xie Z, Zhang H. Recent advance of tellurium for biomedical applications. Chem Res Chin Univ. 2020;36:5519. https://doi.org/10.1007/s40242-020-0193-0.

365. Sredni B. Immunomodulating tellurium compounds as anticancer agents. Semin Cancer Biol. 2012;22:60-9. https://doi.org/ 10.1016/j.semcancer.2011.12.003.

366. Miola M, Massera J, Cochis A, Kumar A, Rimondini L, Vernè E. Tellurium: a new active element for innovative multifunctional bioactive glasses. Mater Sci Eng C. 2021;123:111957. https:// linkinghub.elsevier.com/retrieve/pii/S0928493121000965.

367. Rayman MP. Selenium and human health. Lancet. 2012;379:125668. https://doi.org/10.1016/S0140-6736(11)61452-9.

368. Amaral AFS, Porta M, Silverman DT, Milne RL, Kogevinas M, Rothman N, et al. Pancreatic cancer risk and levels of trace elements. Gut. 2012;61:1583-8. https://gut.bmj.com/lookup/doi/ 10.1136/gutjnl-2011-301086. 
369. Elshami W, Tekin HO, Al-Buriahi MS, Hegazy HH, Abuzaid MM, Issa SAM, et al. Developed selenium dioxide-based ceramics for advanced shielding applications: Au2O3 impact on nuclear radiation attenuation. Results Phys. 2021;24:104099. https://linkinghub.elsevier.com/retrieve/pii/ S2211379721002564.

370. Karan R, Manna P, Maiti PK, Das K. Influence of selenium dioxide $(\mathrm{SeO} 2)$ on properties of bioglass in $\mathrm{SiO} 2-\mathrm{Na} 2 \mathrm{O}-\mathrm{CaO}-$ P2O5 system. J Aust Ceram Soc. 2020;56:1135-45. https://doi. org/10.1007/s41779-020-00459-z.

371. Aksakal B, Demirel M. In vitro study of antimicrobial and cell viability on newly synthesized bioglass-based bone grafts: effects of selenium and silver additions. Proc Inst Mech Eng Part H J Eng Med. 2018;232:1039-47. https://doi.org/10.1177/ 0954411918797968.

372. Lucacel RC, Radu T, Ponta O, Simon V. Novel selenium containing boro-phosphate glasses: preparation and structural study. Mater Sci Eng C. 2014;39:61-6. https://linkinghub.elsevier.com/ retrieve/pii/S0928493114001027.

373. Coughlan A, Haddad HF, Wren AW, Hall MM. An exploratory investigation of the development and evaluation of a novel selenium containing bioactive glass. In: 2013 39th Annual Northeast Bioengineering Conference. 2013. p. 104-6. https:// doi.org/10.1109/NEBEC.2013.49.

374. Wang X, Zhang Y, Ma Y, Chen D, Yang H, Li M. Seleniumcontaining mesoporous bioactive glass particles: physicochemical and drug delivery properties. Ceram Int. 2016;42:3609-17. https://doi.org/10.1016/j.ceramint.2015.11.024.

375. Ikizler BK, Terzioglu P, Tekerek BSO, Yücel S. Effect of selenium incorporation on the structure and in vitro bioactivity of 45S5 bioglass. J Aust Ceram Soc. 2020;56:697-709. https://doi. org/10.1007/s41779-019-00388-6.

376. Hu M, Fang J, Zhang Y, Wang X, Zhong W, Zhou Z. Design and evaluation a kind of functional biomaterial for bone tissue engineering: selenium/mesoporous bioactive glass nanospheres. J Colloid Interface Sci. 2020;579:654-66. https://doi.org/10. 1016/j.jcis.2020.06.122.

377. El-Kady AM, Ali AA, El-Fiqi A. Controlled delivery of therapeutic ions and antibiotic drug of novel alginate-agarose matrix incorporating selenium-modified borosilicate glass designed for chronic wound healing. J Non Cryst Solids. 2020;534:119889 https://doi.org/10.1016/j.jnoncrysol.2020.119889.

378. Whitlow J, Paul A, Polini A. Bioactive materials: definitions and application in tissue engineering and regeneration therapy. In: Marchi J, editor. Advanced Structured Materials. Cham: Springer; 2016. p. 1-17. https://doi.org/10.1007/978-3-319-44249-5_1.

379. Zheng K, Torre E, Bari A, Taccardi N, Cassinelli C, Morra M, et al. Antioxidant mesoporous Ce-doped bioactive glass nanoparticles with anti-inflammatory and pro-osteogenic activities. Mater Today Bio. 2020;5:100041 https://doi.org/10.1016/j. mtbio.2020.100041.

380. Schuhladen K, Stich L, Schmidt J, Steinkasserer A, Boccaccini AR., Zinser E. $\mathrm{Cu}, \mathrm{Zn}$ doped borate bioactive glasses: antibacterial efficacy and dose-dependent in vitro modulation of murine dendritic cells. Biomater Sci. 2020;8:2143-55. http:// xlink.rsc.org/?DOI=C9BM01691K.

381. Lima JM, de Pinheiro Ferreira E, Bonan RF, Silva-Teixeira DN, Goulart LR, de Souza JR, et al. Cytokine regulation from human peripheral blood leukocytes cultured in vitro with silver doped bioactive glasses microparticles. Biomed Res Int. 2019;2019:19. https://www.hindawi.com/journals/bmri/2019/3210530/.

382. Fiume E, Barberi J, Verné E, Baino F. Bioactive glasses: from parent 45S5 composition to scaffold-assisted tissue-healing therapies. J Funct Biomater. 2018;9:24 https://www.mdpi.com/ 2079-4983/9/1/24.
383. Souza MT, Tansaz S, Zanotto ED, Boccaccini AR. Bioactive glass fiber-reinforced PGS matrix composites for cartilage regeneration. Materials (Basel). 2017;10:83 http://www.mdpi. com/1996-1944/10/1/83.

384. Atkinson I, Anghel EM, Petrescu S, Seciu AM, Stefan LM, Mocioiu OC, et al. Cerium-containing mesoporous bioactive glasses: material characterization, in vitro bioactivity, biocompatibility and cytotoxicity evaluation. Microporous Mesoporous Mater. 2019;276:76-88. https://doi.org/10.1016/j.micromeso.2018.09.029.

385. Ribeiro M, Monteiro FJ, Ferraz MP. Infection of orthopedic implants with emphasis on bacterial adhesion process and techniques used in studying bacterial-material interactions. Biomatter. 2012;2:176-94. https://doi.org/10.4161/biom. 22905.

386. Zhu H, Zheng K, Boccaccini AR. Multi-functional silica-based mesoporous materials for simultaneous delivery of biologically active ions and therapeutic biomolecules. Acta Biomater. 2021;129:1-17. https://pubmed.ncbi.nlm.nih.gov/34010692/.

387. Kaur G, Kumar V, Baino F, Mauro JC, Pickrell G, Evans I, et al. Mechanical properties of bioactive glasses, ceramics, glassceramics and composites: State-of-the-art review and future challenges. Mater Sci Eng C. 2019;104:109895. https://doi.org/ 10.1016/j.msec.2019.109895.

388. Curcio M, De Stefanis A, De Bonis A, Teghil R, Rau JV. Pulsed laser deposited bioactive RKKP-Mn glass-ceramic coatings on titanium. Surf Coat Technol. 2019;357:122-8. https://doi.org/10. 1016/j.surfcoat.2018.10.004.

389. Barrioni BR, Naruphontjirakul P, Norris E, Li S, Kelly NL, Hanna JV, et al. Effects of manganese incorporation on the morphology, structure and cytotoxicity of spherical bioactive glass nanoparticles. J Colloid Interface Sci. 2019;547:382-92. https://doi.org/10.1016/j.jcis.2019.04.016.

390. Sarin N, Singh KJ, Singh D, Arora S, Singh AP, Mahajan H. Preliminary studies of strontium and selenium binary doped CaO-SiO2-P2O5-MgO bioceramics for faster growth of hydroxyapatite and bone regeneration applications. Mater Chem Phys. 2020;253:123329 https://doi.org/10.1016/j.matchemphys. 2020.123329 .

391. Moghanian A, Zohourfazeli M, Haji Mahdi Tajer M, Miri AK. Comprehensive in vitro studies of novel sol gel-derived $\mathrm{Zr} 4+/ \mathrm{Zn} 2$ + co-substituted bioactive glass with enhanced biological properties for bone healing. J Non Cryst Solids. 2021;566:120887 https:// doi.org/10.1016/j.jnoncrysol.2021.120887.

392. Ershad M, Vyas VK, Prasad S, Ali A, Pyare R. Synthesis and characterization of cerium- and lanthanum-containing bioactive glass. Key Eng Mater. 2017;751:617-28. https://www.scientific. net/KEM.751.617.

393. Deliormanli AM, Yildirim M. Sol-gel synthesis of 13-93 bioactive glass powders containing therapeutic agents. J Aust Ceram Soc. 2016;52:9-19. https://aperta.ulakbim.gov.tr/record/ 57399\#.YSPDyI4zZPY.

394. Bachar A, Mercier C, Tricoteaux A, Hampshire S, Leriche A, Follet C. Effect of nitrogen and fluorine on mechanical properties and bioactivity in two series of bioactive glasses. J Mech Behav Biomed Mater. 2013;23:133-48. https://doi.org/10.1016/j. jmbbm.2013.03.010.

395. Pazarçeviren AE, Tahmasebifar A, Tezcaner A, Keskin D, Evis Z. Investigation of bismuth doped bioglass/graphene oxide nanocomposites for bone tissue engineering. Ceram Int. 2018;44:3791-9. https://linkinghub.elsevier.com/retrieve/pii/ S0272884217326226.

396. Kalaivani S, Srividiya S, Vijayalakshmi U, Kannan S. Bioactivity and up-conversion luminescence characteristics of $\mathrm{Yb} 3$ +/Tb3+ co-doped bioglass system. Ceram Int. 2019;45:186407. https://doi.org/10.1016/j.ceramint.2019.06.088. 